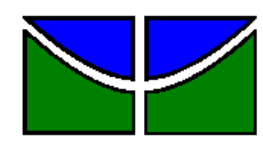

Universidade de Brasília

Faculdade de Economia, Administração e Contabilidade

Departamento de Administração

Curso de Graduação em Administração a distância

Nelson Vilemar Lopes Ferreira Gomes

\title{
AVALIANDO O ALINHAMENTO ENTRE O PLANEJAMENTO ESTRATÉGICO DE NEGÓCIOS E O PLANEJAMENTO ESTRATÉGICO DE TECNOLOGIA DA INFORMAÇÃO: um estudo de caso no Sicoob Confederação
}

Brasília - DF 
Nelson Vilemar Lopes Ferreira Gomes

\section{AVALIANDO O ALINHAMENTO ENTRE O PLANEJAMENTO ESTRATÉGICO DE NEGÓCIOS E O PLANEJAMENTO ESTRATÉGICO DE TECNOLOGIA DA INFORMAÇÃO: um estudo de caso no Sicoob Confederação}

Monografia apresentada a Universidade de Brasília (UnB) como requisito parcial para obtenção do grau de Bacharel em Administração. 
Gomes, Nelson Vilemar Lopes Ferreira Gomes.

Avaliando o alinhamento entre 0 planejamento estratégico de negócios e o planejamento estratégico de tecnologia da informação: um estudo de caso no Sicoob Confederação / Nelson Vilemar Lopes Ferreira Gomes. - Brasília, 2011. $95 \mathrm{f}$. : il.

Monografia (bacharelado) - Universidade de Brasília, Departamento de Administração - EaD, 2011.

Orientador: Prof. Mestre/Doutorando, Victor Manuel Barbosa Vicente, Departamento de Administração.

1. Alinhamento Estratégico. 2. Planejamento Estratégico de Negócios. 3. Planejamento Estratégico de Tecnologia da Informação. I. Título. 
Nelson Vilemar Lopes Ferreira Gomes

\title{
AVALIANDO O ALINHAMENTO ENTRE O PLANEJAMENTO ESTRATÉGICO DE NEGÓCIOS E O PLANEJAMENTO ESTRATÉGICO DE TECNOLOGIA DA INFORMAÇÃO: um estudo de caso no Sicoob Confederação
}

\begin{abstract}
A Comissão Examinadora, abaixo identificada, aprova o Trabalho de Conclusão do Curso de Administração da Universidade de Brasília do aluno
\end{abstract}

Nelson Vilemar Lopes Ferreira Gomes

Prof. Mestre/Doutorando, Victor Manuel Barbosa Vicente Professor-Orientador

Professor Mestre/Doutorando, Victor

Manuel Barbosa Vicente

Professor-Examinador
Professor Doutor, Eduardo Raupp de

Vargas

Professor-Examinador

Brasília, 04 de abril de 2011. 
Dedico este trabalho à Flora, minha esposa, que sempre incentivou e apoiou meus estudos, e as minhas filhas, Carolina Joana e Taiana, pela compreensão nos momentos em que estive ausente. 


\section{AGRADECIMENTOS}

Em primeiro lugar, a Deus, pela tranquilidade emanada nas horas mais difíceis e pela perseverança e confiança que só ele pode irradiar.

Ao MEC, UnB e Banco do Brasil, que através do projeto Piloto do Programa Universidade Aberta do Brasil - UAB propiciaram a oportunidade inédita de oferecer um curso a distância com os mesmos níveis de qualidade dos cursos presenciais da UnB.

Ao meu orientador, Professor Mestre/Doutorando, Victor Manuel Barbosa Vicente, por ter me ajudado a superar as dificuldades encontradas ao longo da pesquisa, fazendo correções de rumo imprescindíveis e que, através da sua assertividade e competência propiciou o desenvolvimento pleno deste trabalho.

Ao Sicoob Confederação, empresa onde trabalho, por ter concordado em participar deste estudo de caso.

A todas as pessoas, enfim, que de várias maneiras puderam me ajudar a empreender esta caminhada. 
"O mais importante ingrediente na fórmula do sucesso é saber como lidar com as pessoas."

Theodore Roosevelt 


\section{RESUMO}

O alinhamento estratégico tem sido um tema abordado por vários autores contemporâneos e é visto como um poderoso instrumento de gestão organizacional, capaz de fornecer as condições para que a empresa possa atuar em consonância com as suas áreas de negócios a fim de otimizar recursos para o alcance eficaz de seus objetivos.

Este estudo foi realizado numa organização que administra um sistema de cooperativas de crédito do Brasil, que possui um banco e uma rede de atendimento aos cooperativados que conta com 1700 pontos de presença na quase totalidade do território nacional.

O método de pesquisa empregado foi o de estudo de caso e a coleta de dados se deu pela aplicação de questionário, constante do Anexo 1, com base no modelo de alinhamento estratégico proposto por Rezende (2002).

A partir das respostas analisadas, pode-se identificar o nível de maturidade do alinhamento entre o Planejamento Estratégico de Tecnologia da Informação (PETI) e o Planejamento Estratégico de Negócios (PEN). O percentual médio de alinhamento estratégico do Sicoob, segundo a percepção de gestores e analistas da área de $\mathrm{TI}$, foi de $42,6 \%$. Segundo o modelo utilizado para essa mensuração, o construto que contribui com maior peso para a promoção do alinhamento estratégico é o Contexto Organizacional (CO) contrastando com o construto Pessoas ou Recursos Humanos $(\mathrm{RH})$ que foi o que apresentou menor peso.

Os resultados obtidos pela pesquisa destacaram elementos que poderão embasar futuros estudos, ressaltando a importância da harmonia entre as áreas de negócios da organização com a área de TI, buscando a otimização do desempenho e a eficácia almejada. Os demais resultados observados encontram-se nos detalhamentos das análises descritas.

Esse estudo se propõe a contribuir para o resgate da visão moderna do planejamento da $\mathrm{TI}$ alinhado ao negócio empresarial, através de uma visão sistêmica da organização e descartando os velhos planos diretores com foco direcionado apenas a $\mathrm{TI}$. 
A conclusão do estudo ratifica a relevância do alinhamento do PETI ao PEN e ressalta a necessidade dos recursos sustentadores serem trabalhados em conjunto, de modo adequado e competente, a fim de contribuírem para gestão de uma organização mais competitiva e inteligente.

Palavras-chave: Planejamento Estratégico; Planejamento Estratégico de Negócios; Planejamento Estratégico de Tecnologia da Informação; Alinhamento Estratégico. 


\section{LISTA DE ILUSTRAÇÔES}

Figura 1 - Teoria do Planejamento Estratégico de $\mathrm{TI}$........................................21

Figura 2 - Modelo proposto por Rezende ................................................

Figura 3 - Modelo Organizacional do Sicoob .................................................. 34

Figura 4 - Mapa Estratégico do Sicoob..................................................... 37

Figura 5 - Fases da Elaboração do PETI do Sicoob.......................................39

Figura 6 - A Metodologia BSC na Definição dos Indicadores ..............................44 


\section{LISTA DE TABELAS}

Tabela 1 - Relação dos Construtos Segundo o Modelo de Rezende.......................31

Tabela 2 - Forças que Compõem o Negócio da Organização ...................................36

Tabela 3 - Visão, Missão e Valores do Sistema Sicoob............................................36

Tabela 4 - Fases da Elaboração do PETI do Sicoob ............................................40

Tabela 5 - Missão, Visão e Valores Declarados do PETI do Sicoob..........................41

Tabela 6 - Objetivos Estratégicos do PETI do Sicoob ..........................................42

Tabela 7 - Níveis de Mensuração do Protocolo de Análise …………......................61

Tabela 8 - Resumo das Respostas Tipo "a" do Questionário Aplicado......................61

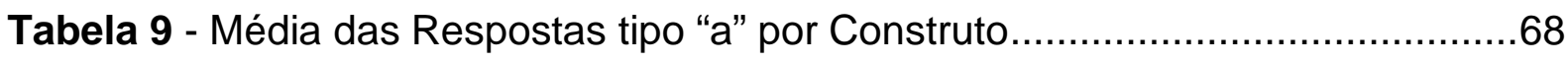

Tabela 10 - Percepção dos Entrevistados Quanto ao Percentual de Alinhamento...70 


\section{LISTA DE ABREVIATURAS E SIGLAS}

$\begin{array}{ll}\text { AE } & \text { - Alinhamento Estratégico } \\ \text { AE } & \text { - Ambiente Externo } \\ \text { AL } & \text { - Alinhamento do Plano Estratégico de TI com o plano de } \\ & \text { Negócio da Organização } \\ \text { AI } & \text { - Ambiente Interno } \\ \text { BANCOOB } & \text { - Banco Cooperativo do Brasil } \\ \text { BSC } & \text { - Balanced Scorecard } \\ \text { CO } & \text { - Contexto Organizacional } \\ \text { DIREX - TI } & \text { - Diretoria Executiva - TI } \\ \text { FGS } & \text { - Fundo Garantidor do Siccob } \\ \text { IP } & \text { - Implementação do Plano } \\ \text { PEE } & \text { - Planejamento Estratégico Empresarial } \\ \text { PEN } & \text { - Planejamento Estratégico de Negócio } \\ \text { PETI } & \text { - Planejamento Estratégico da Tecnologia de Informação } \\ \text { PI } & \text { - Plano de Informação } \\ \text { PP } & \text { - Planejamento de Processos } \\ \text { PR } & \text { - Planejamento de Recursos } \\ \text { RH } & \text { - Recursos Humanos } \\ \text { SI } & \text { - Sistemas de Informações e de Conhecimentos } \\ \text { SICOOB } & \text { - Sistema de Cooperativas de Crédito do Brasil } \\ \text { SWOT } & \text { - Strenghts, Weaknesses, Opportunities e Threat } \\ \text { TI } & \text { - Tecnologia da Informação } \\ \text { ZOPP } & \text { - ZlEL (Objetivos), ORIENTIERTE (Orientados), PROJEKT } \\ & \text { (Projetos) e PLANUNG (Planejamento) }\end{array}$




\section{SUMÁRIO}

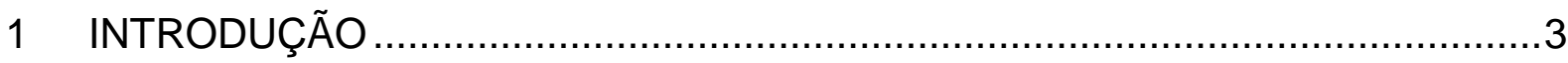

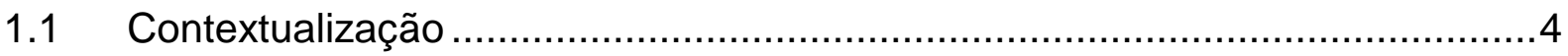

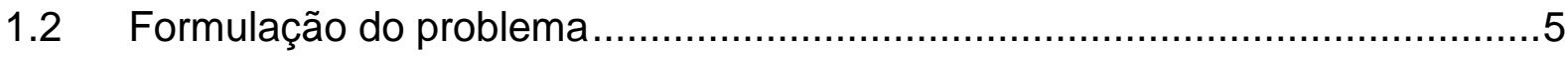

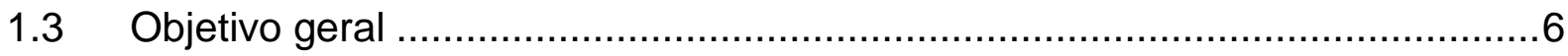

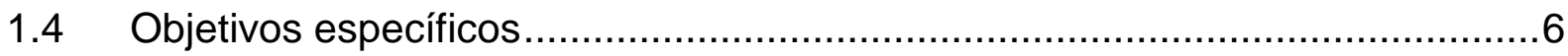

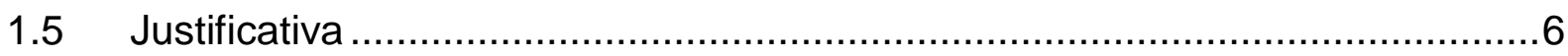

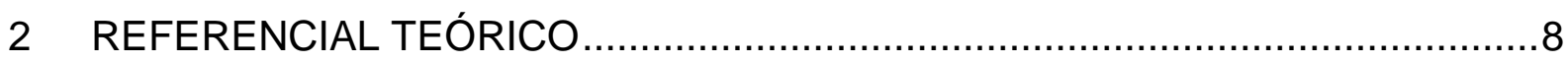

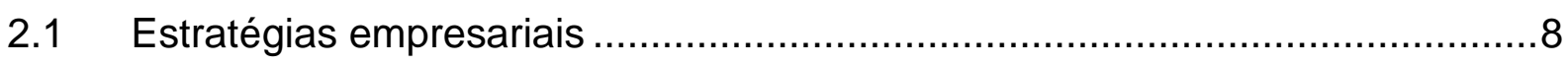

2.2 Estratégia competitiva ......................................................................

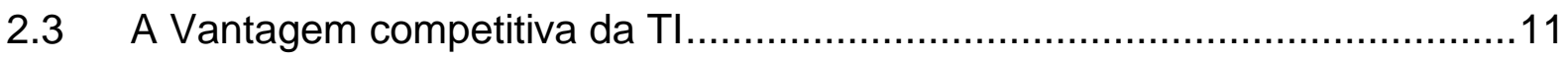

2.4 Planejamento estratégico empresarial..................................................15

2.5 Planejamento estratégico da tecnologia da informação (PETI) .....................17

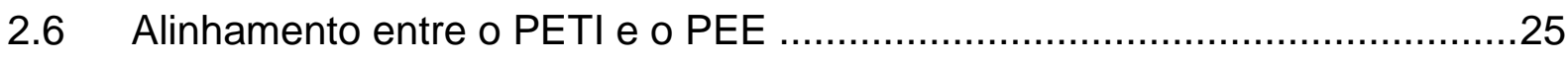

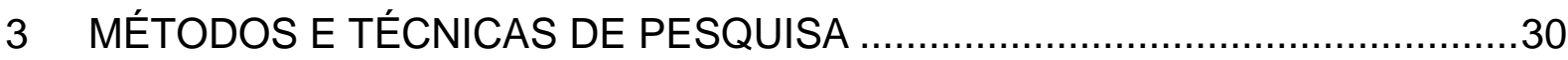

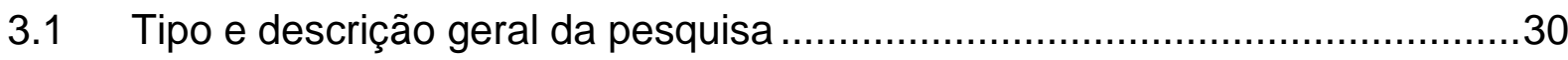

3.2 Caracterização da organização, setor ou área do objeto de estudo................34

3.3 Metodologia de formulação do PEE do Sicoob ……………………...........35

3.4 Metodologia de formulação do PETI do Sicoob...............................................39

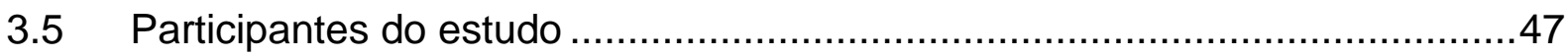

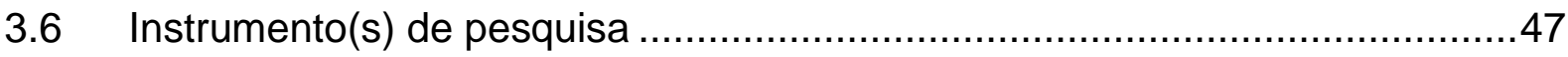

3.7 Procedimentos de coleta e de análise de dados ..........................................48

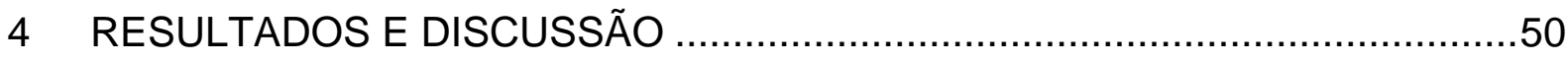

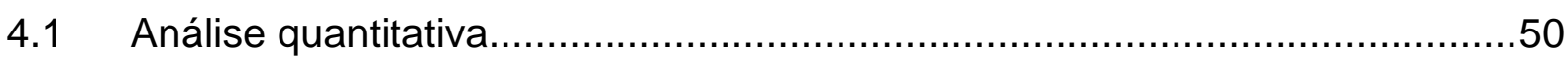

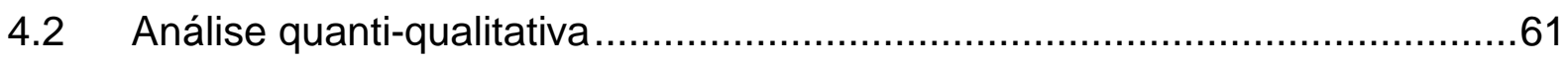

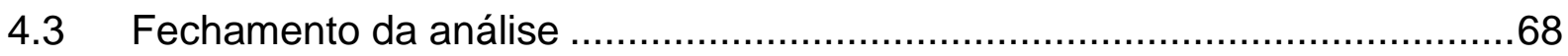


4.3.1 Análise das respostas das variáveis ..........................................68

4.3.2 Análise do percentual do alinhamento do PETI ao PEE ...........................70

4.3.3 Análise das respostas das questões abertas ....................................71

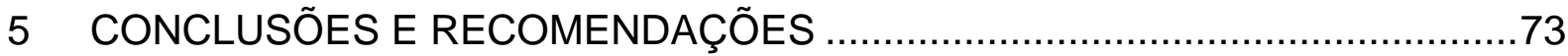

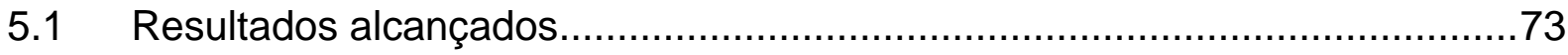

5.2 Relação entre os objetivos da pesquisa e a conclusão alcançada.................75

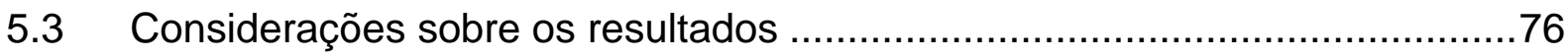

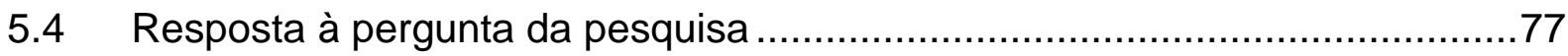

5.5 Limitações e contribuições do estudo................................................. 77

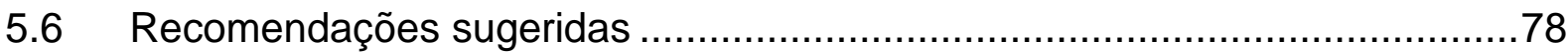

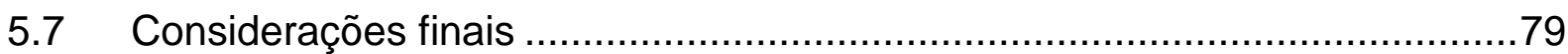

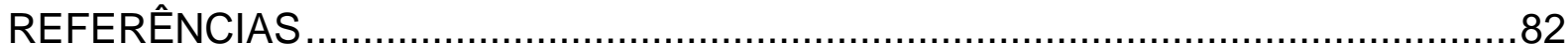

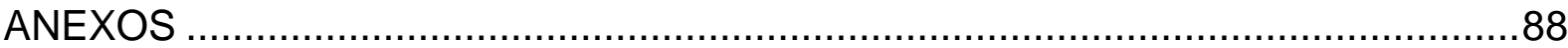

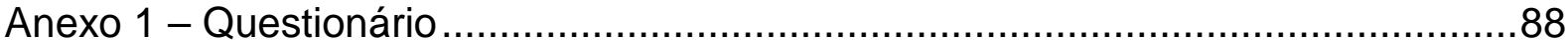




\section{INTRODUÇÃO}

Dentre os principais instrumentos de gestão adotados pelas organizações, como forma de promover um direcionamento aos seus objetivos de negócio de médio e longo prazo, destaca-se o Planejamento Estratégico Empresarial (PEE). Mais recentemente têm-se observado a grande demanda, por parte das empresas, quanto à necessidade de sistemas de informações suportados por recursos da Tecnologia da Informação (TI), como importantes ferramentas de sustentação aos seus processos decisórios (REZENDE et al., 2000).

Dessa forma, torna-se imprescindível que a área de TI também construa seu planejamento estratégico, de forma a adequar seus recursos às necessidades das áreas de negócios da organização.

O grande desafio das atuais organizações, caracterizadas pela atuação num mercado bastante competitivo, mutante e globalizado, é, sem dúvida, promover a sinergia entre os planejamentos estratégicos empresarial (PEE) e de TI (PETI), de forma a alinhar as estratégias que deverão nortear a sua atuação futura como fornecedoras de produtos e/ou serviços (REZENDE e ABREU, 2002).

Nos últimos anos, o alinhamento estratégico tem sido considerado um poderoso instrumento de gestão empresarial, determinante para a atuação integrada das áreas de negócios, consolidando recursos e buscando o alcance eficaz de seus objetivos (FREITAS, 2007).

Com relação às empresas brasileiras de médio e grande porte, estima-se que cerca de $40 \%$ dos investimentos de capital realizados sejam feitos em informática, avançando para $80 \%$ ao analisar-se o setor bancário de forma isolada (MEIRELLES, 2004). Isso demonstra a importância da TI para o funcionamento do sistema financeiro nacional, não somente pelo volume de investimentos no setor, mas também pelo aumento da automação e dos níveis de serviços oferecidos pelos sistemas bancários informatizados.

Nesse contexto, além das instituições financeiras mais tradicionais, como os grandes bancos, encontram-se organizações estabelecidas em nichos mais emergentes dentro do sistema financeiro nacional. Esse é o caso das cooperativas de crédito, cuja presença no mercado tem sido marcada pela constante expansão da 
base de clientes e de sua movimentação financeira, utilizando a TI como importante suporte para o processamento dos seus sistemas de negócios.

Este estudo se propõe a realizar pesquisa sobre o estágio de alinhamento entre o PEE e o PETI, numa instituição responsável por um sistema de mais de 500 cooperativas de crédito, com 1.700 pontos de atendimento e com atuação em quatorze grandes regiões do território brasileiro, denominada Confederação Nacional das Cooperativas do Sicoob (Sicoob Confederação).

É nesse cenário que o problema de pesquisa deste trabalho se estabelece: Como avaliar o estágio de maturidade atual quanto ao alinhamento estratégico entre os PEE e PETI no Sicoob Confederação.

\subsection{Contextualização}

As ferramentas administrativas voltadas para 0 planejamento das organizações tiveram origem na área financeira com o orçamento, cuja evolução resultou no planejamento a longo prazo, projetando o orçamento para um número maior de anos, desconsiderando as mudanças no ambiente.

Como resultado da necessidade de promover correções de rumo na direção da empresa como forma de adaptação às mudanças ambientais, desenvolveu-se o mecanismo de planejamento estratégico. Consequentemente os administradores perceberam que a visão estratégica deveria ser mais sistêmica dentro da organização, não se prendendo somente a função do planejamento. A abordagem estratégica deveria contemplar as outras funções como, organizar, dirigir e controlar, além de, no nível estratégico, auxiliar na capacitação da empresa.

As instituições financeiras têm conseguido sobreviver às mudanças do ambiente através dos seus mecanismos de adaptação às constantes transformações. Entretanto, nos dias atuais, enfrentam grandes desafios relacionados à forte concorrência, às incertezas do ambiente, às crises internas e externas, à forte dependência de tecnologia, as novas demandas do mercado, as fortes imposições dos órgãos reguladores, dentre outros. 
Dentro dessa variedade de fatores, o planejamento estratégico passa a ser um elemento imprescindível para as organizações. É através dele que é possível avaliar riscos e oportunidades, antever tendências, definir objetivos, fazer ajustes na organização e enfrentar novas realidades.

Com o planejamento estratégico almeja-se que os diversos segmentos da organização atinjam a eficácia desejada. Para isso, é necessário que a administração estratégica esteja atuante em todas as áreas, não apenas na área de negócios, mas também nas áreas de apoio como é o caso da área de Tecnologia da Informação.

Além da elaboração dos planos, as organizações devem utilizar ferramentas que promovam o alinhamento entre o planejamento estratégico de negócios e o planejamento estratégico de TI, buscando a melhor utilização possível de seus recursos para o atingimento dos objetivos maiores da organização.

O cenário atual mostra a importância cada vez maior do alinhamento para o desempenho organizacional como um todo, durante o processo de elaboração dos planejamentos estratégicos e também dos processos que responsáveis pelo controle e acompanhamento de sua execução.

Dentro desse contexto é necessário verificar junto às organizações o quanto os planejamentos de negócios e de TI estão alinhados, de forma a perceber quais fatores precisam ser melhor trabalhados e quais os que estão contribuindo em maior escala para a promoção dessa sinergia entre as áreas mais críticas da empresa.

\subsection{Formulação do problema}

Qual o estágio de maturidade atual quanto ao alinhamento entre o Plano Estratégico de Negócios e o Plano Estratégico de TI no Sicoob Confederação? 


\subsection{Objetivo geral}

Identificar o estágio de maturidade atual quanto ao alinhamento entre o Plano Estratégico de Negócios (PEE) e o Plano Estratégico de T.I. (PETI) no Sicoob Brasil.

\subsection{Objetivos específicos}

- identificar como são formulados os PEE e PETI da empresa;

- Estabelecer e aplicar um modelo de mensuração para a aferição do grau de maturidade do alinhamento estratégico entre os negócios e a TI, baseado em pesquisa com os gerentes e analistas da área de TI do Sicoob Brasil;

- Identificar, através do modelo adotado para a mensuração do alinhamento estratégico, quais os recursos sustentadores que mais contribuem para o alinhamento estratégico entre o PEE e o PETI da empresa; e

- Identificar, através do modelo adotado, quais os recursos sustentadores que precisam ser mais bem trabalhados a fim de promoverem um maior alinhamento estratégico entre o PEE e o PETI da empresa.

\subsection{Justificativa}

Nos anos que antecederam à globalização, deflagrada principalmente pelo fim da guerra fria e tendo como símbolo principal a derrubada do Muro de Berlim, podíamos observar o domínio da tecnologia por um pequeno conjunto de países ricos (SCHILLING e VOLTAIRE, 2010). Hoje, depois de pouco mais de duas décadas, não podemos conceber empresas, principalmente de médio e grande porte, que não façam uso de tecnologias para o alcance de seus objetivos estratégicos.

Compreender que, politicamente, a globalização representa uma expansão de regimes democráticos e, tecnologicamente, representa a democratização quanto ao uso de ferramentas que permitem a integração e a elevação da qualidade de vida dos povos em geral, nos ajuda a entender a importância da Tecnologia da 
Informação - TI para as organizações a nível mundial (SCHILLING e VOLTAIRE, 2010).

Desde que a $\mathrm{Tl}$ começou a ser utilizada como ferramenta de apoio para as áreas de negócios das empresas, certa preocupação tomou conta dos gestores quando da execução dos orçamentos anuais das organizações. O emprego massivo de TI chegou a ser dúvida para dirigentes que não conseguiam mensurar o retorno sobre os investimentos que eram realizados em ativos de informática. Com o aprimoramento dos sistemas informatizados para apoio aos negócios e a evolução das soluções de automação dos processos empresariais baseadas em TI, essa incerteza recuou e, atualmente os gestores não mais descartam a TI como alavancadora de resultados.

Um dos instrumentos mais importantes da gestão empresarial é o Planejamento Estratégico de Negócios - PEN que, até bem pouco tempo, era elaborado de forma independente pelas áreas de negócios da organização. Nesse contexto, a área responsável pela gestão de TI desenvolvia o Planejamento Estratégico de Tecnologia da Informação - PETI, tendo como balizadores principais as estatísticas e os dados históricos de utilização de recursos tecnológicos. Estes dados permitiam uma estimativa para a atuação futura da $\mathrm{TI}$ enquanto braço de apoio aos sistemas de negócios da organização.

Atualmente, o grande desafio para as empresas que querem continuar atuando de forma responsável no mercado é a busca do alinhamento estratégico entre o PEN e o PETI. É com essa sinergia que a gestão empresarial consolida recursos e busca o alcance eficaz de seus objetivos (Freitas, 2007).

Os resultados observados nesta pesquisa propiciarão ao Sicoob Brasil, sob a ótica dos seus executivos de TI, uma visão quanto ao estágio em que se encontra o alinhamento estratégico entre PEN e PETI. Essa percepção servirá para indicar possíveis correções de rumo na condução da elaboração do PETI, de forma a estimular o aprimoramento do processo de alinhamento com os objetivos das áreas de negócios da empresa.

Da mesma forma, a área de negócios poderá, através das análises advindas desta pesquisa, fazer as suas críticas sobre o processo, conhecendo melhor os pontos de vista da área de TI e identificando o que mais pode ser feito para maximizar o equilíbrio entre as duas áreas. 
Segundo Rezende e Abreu (2002), a literatura disponível sobre o assunto ainda se encontra apoiada em modelos de alinhamento existentes e não demonstra o cotidiano real das empresas quanto aos obstáculos de implementação e aos resultados obtidos pela organização, já que dependem de fatores como os humanos, sociais, culturais, políticos, organizacionais, sistêmicos e tecnológicos.

\section{REFERENCIAL TEÓRICO}

Para a elaboração do trabalho de conclusão do curso é importante destacar algumas visões de cunho teórico a cerca dos conceitos que envolvem as estratégias empresariais, estratégias competitivas e o planejamento estratégico de negócios e de $\mathrm{TI}$, dentro de uma sequência lógica que facilite a familiarização com os termos e o embasamento do assunto.

São diversas as contribuições teóricas sobre o tema das estratégias empresariais, planejamento estratégico e alinhamento estratégico entre os planos de tecnologia da informação e os planos de negócio.

\subsection{Estratégias empresariais}

O início do referencial teórico nos remete ao conceito de estratégia conforme exposto por Mintzberg et al (2006, p. 78):

A estratégia corporativa é o modelo de decisões de uma empresa que determina e revela seus objetivos, propósitos ou metas, produz as principais políticas e planos para atingir essas metas e define o escopo de negócios que a empresa vai adotar, o tipo de organização econômica e humana que ela é ou pretende fazer para seus acionistas, funcionários, clientes e comunidades... 
A palavra estratégia advém do grego strategós e significa literalmente "comandante do exército". Durante séculos, foi utilizada pelos militares com o intuito de explorar condições que favorecessem o seu o seu principal objetivo que era a vitória militar. Entretanto, ao longo do tempo, a palavra estratégia passou a ser de uso comum.

Por isso há várias abordagens para o conceito de estratégia. Alguns a veem como um plano ou uma direção ou ainda um curso de ação para o futuro. Estratégia é um padrão, ou seja, representa um comportamento consistente ao longo do tempo (MINTZBERG et al., 2000).

Estratégia segundo Porter (1986), "é a manobra para atingir uma vantagem competitiva, pelo bom posicionamento da empresa em um setor econômico na qual se insere, graças ao bom conhecimento da cadeia de valor".

Para Serra, Torres e Torres (2004), é "a determinação de metas e dos objetivos básicos a longo prazo de uma empresa, bem como a adoção de cursos de ação e alocação dos recursos necessários à consecução dessas metas."

A estratégia é, portanto, um ponto alto das atividades dos executivos, para atingir resultados consistentes com as missões e objetivos das organizações planos para o futuro com visão no passado.

Andrews in Mintzberg e Quinn (2001, p. 58) define estratégia como:

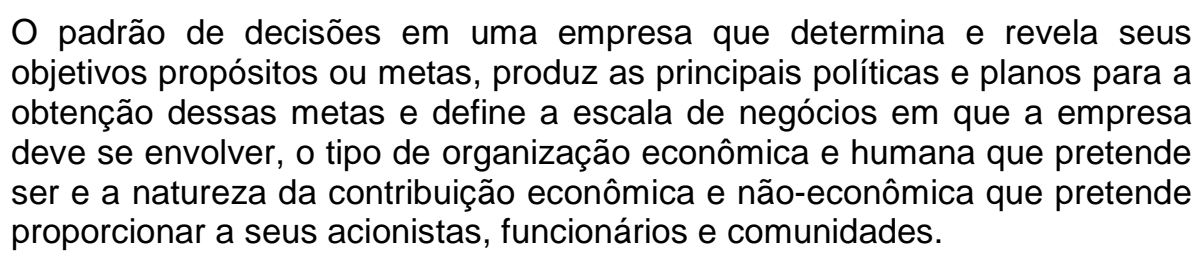

Mintzberg et al. (2006) fazendo uma analogia das pessoas que desenvolvem personalidades através da interação de suas características, com a organização que também desenvolve um caráter a partir do seu relacionamento com o mundo através de suas habilidades e tendências naturais. O autor constrói uma definição mais completa de estratégia tendo como base o conjunto de outras cinco definições: 
- plano - a estratégia tem por finalidade estabelecer direções para a organização;

- trama - a estratégia é aplicada como manobra para ameaçar e confundir os concorrentes, na busca de ganho de vantagem;

- padrão - a estratégia leva em conta o comportamento e a assimilação de ações de sucesso no processo decisório da organização;

- posição - a estratégia encoraja as organizações a analisarem o ambiente, buscando uma posição que as protejam, visando defender-se e influenciar a competição; e

- perspectiva - a estratégia traz questões referentes a intenção e comportamento em um contexto coletivo.

Segundo Porter (1991), diversas técnicas, teorias e modelos de gestão têm se desenvolvido como resultado da evolução do conceito de estratégia de negócios, possibilitando que as organizações elaborem um direcionamento para seus negócios.

\subsection{Estratégia competitiva}

Além do aspecto genérico da estratégia, existe a necessidade da empresa estabelecer estratégias para concorrer com outras empresas. Nesse caso aparece mais um conceito denominado de estratégia competitiva.

Dentre as várias definições para o termo 'estratégia competitiva', Ansoff (1990) destaca que é um tipo de estratégia que destina especial atenção para as ações que a organização tentará utilizar para ser bem sucedida em cada uma das áreas estratégicas de negócio, quer seja visando à expansão da participação no mercado, o crescimento, a diferenciação de mercado ou a diferenciação de produtos e serviços.

A definição de estratégia competitiva deve satisfazer alguns critérios segundo Fernandes (2003). Ela deve ser singular, concorrendo para uma clara e maior diferenciação entre a empresa e seus concorrentes, destacando-a como única ou singular. Deve orientar escolhas importantes no decorrer do tempo por conta das 
mutações de outros atores do cenário, como os concorrentes ou fornecedores. Deve valorizar o conhecimento e as pessoas que trabalham na empresa e por último, empregar tecnologia para gerar valor.

O enfoque de Mintzberg et al (2000) sobre o tema, nos revela que a estratégia competitiva, ao contrário da estratégia genérica, tem foco nas diferenças entre as organizações e não propriamente em suas missões comuns. Nesse sentido o problema a ser abordado não é como uma função pode ser desempenhada por uma empresa, mas sim como ela pode ser feita melhor em relação aos concorrentes ou pelo menos igual. Ainda segundo o autor, vantagens competitivas podem ser associadas a habilidades superiores, recursos superiores ou posição superior.

Outra visão sobre o mesmo tema pode ser vista em Porter (1989, p. 1):

A concorrência está no âmago do sucesso ou do fracasso das empresas, determinando a adequação das atividades que podem contribuir para seu desempenho, como inovações, uma cultura coesa ou uma boa implementação. A estratégia competitiva é a busca de uma posição competitiva favorável em uma indústria, a arena fundamental onde ocorre a concorrência. A estratégia competitiva visa a estabelecer uma posição lucrativa e sustentável contra as forças que determinam a concorrência na indústria.

\subsection{A Vantagem competitiva da TI}

Primeiramente, faz-se necessário conceituar Tecnologia da Informação Deste modo Wiener (1997) apontando uma conceituação com base em procedimento mais técnico nota-se que a Tecnologia da Informação ( $\mathrm{TI})$, afirma que:

Está diretamente ligada ao desenvolvimento do computador, e assim sendo, uma nova forma de disseminação da informação e potencialização dos conceitos; Viver efetivamente é viver com informação adequada. A comunicação e o controle, portanto, são integrantes da essência da vida interior do homem, na mesma medida em que fazem parte de sua vida em sociedade (WIENER, 1997, p.19). 
Para esse autor a Tecnologia da Informação diz respeito "ao desenvolvimento do computador" o que pode ser entendido como uma forma implementada por sistema tecnológico capaz de disseminar determinada quantidade de informação que passa fazer parte do cotidiano humano.

$\mathrm{Na}$ interpretação de Foina (2001, p.187), a tecnologia da informação é o "conjunto de tecnologias, metodologias e procedimentos que atuam em coleta, tratamento e disseminação das informações na organização".

Inerente aos procedimentos diários de uma organização, a Tecnologia da Informação possui o papel de disseminar informações que serão utilizadas na sua administração com o propósito de facilitar e viabilizar as atividades da organização seja privada ou pública.

$\mathrm{Na}$ visão de Keen (1993) apud Laurindo (2001) ao apontar que a Tecnologia da Informação por estar mais ligada a procedimentos administrativos e também organizacionais relacionados mais diretamente com a ação humana possui um conceito que se torna ainda mais abrangente do que os já conhecidos e utilizados "processamento de dados", "sistema de informação", "engenharia de software", "informática ou o conjunto de hardware" e "software".

Dessa forma é possível compreender que a Tecnologia da Informação ligase não apenas a elementos tecnológicos no âmbito da informática, mas também a aspectos ligados a administração e gerenciamentos. Procedimentos estes que são inerentes ao desenvolvimento de qualquer organização e que ocorrem em consonância com as atividades humanas no cotidiano.

Para Castro (2004), esta tecnologia tem se tornado um instrumento de profunda eficácia nas atividades organizacionais, pois oferece suporte nas tomadas de decisões, atua como elemento de estratégia para o desenvolvimento interno e externo da organização e confere sustentação para a competitividade no mercado. Vale ressaltar que ao tratar de organização pública implementa agilidade e melhor atendimento à sociedade.

Observa-se uma crescente competitividade especialmente no mercado globalizado e na esfera pública tem-se uma demanda cada vez maior por agilidade nos processos de atendimento à população e assim, apresenta-se profunda evolução na abrangência da Tecnologia da Informação além de avanços de sua capacidade tecnológica transformando-a em instrumento administrativo com 
capacidade de ampliar e melhorar a gestão organizacional e promover estratégias de ação (LAURINDO et al, 2001).

Conforme pode ser verificado em seu início o sistema de computação era entendido como elemento para "automatizar" as atividades das empresas, principalmente as grandes, além de ser usada também nas tarefas governamentais. A partir do avanço dessa tecnologia que veio sendo melhorada no decorrer dos tempos, essas máquinas que em sua origem era grande e tomava muito espaço físico tem sido reduzida em espaço, porém ampliada em capacidade de atuação (ALECRIM, 2004).

Sua evolução ocorreu em vários campos e tem deixado sua marca e se feito cada dia mais presente nas atividades das telecomunicações, que a exemplo da internet faz com as noções de tempo e espaço, sejam superadas especialmente para o mundo dos negócios.

Nesse ínterim pode-se entender que a informação trata-se de "um patrimônio" isto é, é um elemento presente na vida humana e propagada pela tecnologia que precisa e é valorizado, haja vista que muitas vezes a vida, ou seja, o desempenho de uma organização depende da informação (ALECRIM, 2004). A informação no contexto atual precisa ser vista além de um sem número de dados e sim algo a ser utilizado pelas organizações privadas e públicas e revertidas como benefício a toda sociedade.

Conforme aponta Alecrim (2004) é possível definir a Tecnologia da Informação como conjunto que engloba atividades promovidas por recursos computacionais. Desse modo pode-se ter na Tecnologia da Informação, um instrumento cujas atividades uma vez aplicadas com coerência, são decisivas para promover soluções e recursos de gestão a empresa pública ou privada.

A Tecnologia da Informação possui um valor estratégico e esse valor associado à informação, pode ser incluído como uma tecnologia que atua nas operações de um setor privado ou público melhorando seus produtos e ou serviços, o relacionamentos com parceiros e sociedade (ALBERTIN, 2001).

A Tecnologia da Informação tem como propósito implementar atividades cotidianas em esferas privadas e pública e assim atender a demanda de atividades de forma ágil e eficaz. Contudo para que isso ocorra de forma precisa, é necessário planejamento das estratégias. 
Segundo McGee e Prusak (1994), nas últimas três décadas o mundo empresarial tem se transformado de uma economia industrial para uma economia de informação, num cenário onde a competição entre as organizações ocorre baseada na capacidade de obter, tratar, analisar e aplicar a informação de forma eficaz.

Numa linha semelhante, tem-se a abordagem de Goldman (1995):

\begin{abstract}
Estamos saindo de um ambiente competitivo no qual os produtos e serviços do mercado de massa eram padronizados, de vida longa, pobres em informação e trocados em transações unitárias, para um ambiente no qual as empresas concorrem mundialmente com produtos e serviços de nicho de mercado que são individualizados, de vida curta, ricos em informação e trocados em uma base contínua com os clientes.
\end{abstract}

Complementando o pensamento acima, encontramos na obra de Porter e Millar (1985) uma importante visão sobre a TI como diferencial competitivo para as empresas. Os autores enfatizam a rapidez com que a $\mathrm{Tl}$ assumiu papéis mais abrangentes, não restringindo sua atuação apenas a máquinas e computadores, mas passando a tratar das informações geradas pela empresa e incluindo tecnologias convergentes e vinculadas para o seu processamento. Os mesmos autores continuam abordando o tema destacando a $\mathrm{TI}$ como elemento de contribuição estratégica por conta da sua influência no desenvolvimento de estratégias genéricas. Ressaltam ainda que a TI é capaz de modificar a estrutura de custos da organização ao longo da sua cadeia de valores, trazendo benefícios mesmo para tarefas não repetitivas. Quanto à diferenciação, a TI modifica o papel da empresa e altera os seus produtos para os clientes, agregando-lhes personalização e mais informação.

Segundo O'Brien (2002, p. 29), a tecnologia da informação é um requisito estratégico para o desenvolvimento e entrega de produtos ágeis. Os sistemas de informação fornecem as informações de que as pessoas necessitam para apoiar operações ágeis, bem como as informações embutidas em produtos e serviços.

Sendo assim a Tecnologia da Informação vai atuar nas diferentes perspectivas para atender as diversas necessidades das organizações, sem, contudo perder de vista seu objetivo (CASTRO, 2004). Por isso esta tecnologia constitui uma ferramenta de extrema importância, pois facilita não apenas a 
comunicação em si, mas a interação entre setores internos e externos da instituição que a adotar. E desse modo agrega melhorias em seus trabalhos.

Portanto, "as atividades da área de tecnologia da informação devem, então, estar voltadas para atender às estratégias organizacionais e aos objetivos de negócio, atuando conjuntamente com as demais áreas da organização" (CASTRO, 2004, p. 56).

Conforme apontado no trecho acima o intuito da tecnologia da informação está centrada no melhor atendimento das estratégias das organizações bem como atender seus objetivos trabalhando em conjunto dos demais setores da organização. Nesse sentido torna de fundamental importância o Planejamento Estratégico, visto que com por meio desse se alcançará o alinhamento estratégico para implementar tarefas.

Para que essa implementação ocorra torna-se de fundamental importância a elaboração de um Planejamento Estratégico da Tecnologia da Informação (PETI), que, segundo Rezende (2002, p. 19), trata-se de:

Um processo dinâmico e interativo para estruturar estratégica, tática e operacionalmente as informações organizacionais, a TI (e seus recursos: hardware, software, sistemas de telecomunicação, gestão de dados e informação), os sistemas de informação e do conhecimento, as pessoas envolvidas e a infra-estrutura necessária para o atendimento de todas as decisões, ações e respectivos processos da organização.

Portanto, falar-se-á a seguir sobre o Planejamento Estratégico para, então, adentrar no tópico sobre o Planejamento Estratégico de TI.

\subsection{Planejamento estratégico empresarial}

O estudo do planejamento estratégico empresarial (PEE) conforme se conhece hoje teve inicio na metade do século XX em virtude da necessidade das empresas em decidirem onde e como operarem no futuro. 
Para Oliveira (2005) o Planejamento Estratégico é "um processo gerencial que possibilita ao executivo estabelecer o rumo a ser seguido pela empresa com vistas a obter um nível de otimização na relação da empresa com o seu ambiente".

Maximiano (2000) compreende o planejamento estratégico como o "procedimento de elaborar uma estratégia em base da análise dos ambientes externo e interno da organização e consiste em definir objetivos para a relação com o ambiente, levando em conta os desafios e as oportunidades internos e externos".

Ao pensarmos em planejamento e estratégia, logo voltamos o pensamento para autores como Drucker, que conceitua planejamento como:

\begin{abstract}
Planejamento é o processo continuo de, sistematicamente e com maior conhecimento possível do futuro contido, tomar decisões atuais que envolvam; organizar sistematicamente as atividades necessárias à execução dessas decisões; e através de uma retroalimentação organizada e sistemática, medir o resultado dessas decisões em confronto com expectativas alimentadas (DRUCKER, 1999, p. 133).
\end{abstract}

Kotler e Amstrong (2000) definem o Planejamento Estratégico "como o processo gerencial de desenvolver e de manter uma direção estratégica que alinhe as metas e os recursos da organização com suas mutantes oportunidades do mercado". Assim, pode-se compreender a relevância do Planejamento Estratégico como forma de permanência no mercado globalizado,

Uma reflexão importante para este estudo pode ser encontrada na obra de Pereira (2007, p. 67) onde o autor nos apresenta uma definição sobre o planejamento de longo prazo:

Num universo onde as transformações estão cada vez mais aceleradas, fica evidenciado que é essencial a realização de esforços por parte das empresas e da administração pública para vislumbrar o futuro. Devemos recordar que o planejamento estratégico é o processo adequado para mobilizar as pessoas, as 
empresas e os governos para construir e definir claramente o futuro que aspiram. É o planejamento de longo prazo.

O planejamento estratégico pode ser associado ao desempenho das organizações como um de seus fatores básicos de sucesso. Sob essa ótica, Cecato (2002) afirma que as empresas que não tiverem a capacidade de se planejar e se diferenciarem umas das outras, nos próximos anos, serão facilmente eliminadas pelos concorrentes.

Para reforçar essa afirmação, é importante observar o trabalho de Born (2006), onde, segundo o autor, para uma organização construir o seu futuro é necessário um direcionamento dos seus recursos humanos, materiais e financeiros através de uma combinação própria e da forma mais diferenciada possível.

A responsabilidade da elaboração do planejamento estratégico é, em geral, dos níveis hierárquicos mais altos da empresa, já que deve ser pautado nas formações dos objetivos e a seleção dos cursos a serem seguidos.

Os diversos direcionamentos da organização são estruturados através do planejamento estratégico que, segundo Rezende (2002), se dá pela técnica administrativa de análise do ambiente interno e externo, das ameaças e oportunidades, dos seus pontos fortes e fracos, viabilizando, dessa forma, a definição, por parte dos executivos, de um rumo para a organização.

Portanto o Planejamento Estratégico Empresarial é um importante instrumento de gestão para as organizações na atualidade, já que com ele os gestores e equipe poderão ter ferramentas que os municie de informações para a tomada de decisão, auxiliando-os a atuar de forma proativa, antecipando-se às mudanças que ocorrem no mercado em que atuam.

\subsection{Planejamento estratégico da tecnologia da informação (PETI)}

As organizações enfrentam cada vez mais um mercado turbulento, globalizado e repleto de incertezas. Para fazer frente a esse cenário dinâmico os gestores empresariais necessitam de informações tempestivas e de conhecimentos 
adequados à sua atividade como forma de orientação para os seus processos decisórios.

Na visão de Drucker (1996), as organizações passaram da condição de administradoras de recursos físicos para aplicar a informação e o conhecimento em ferramentas, produtos e processos, na elaboração do trabalho e no próprio conhecimento.

Enfatizando esse raciocínio, Morton (1991) assinala que o papel estratégico da $\mathrm{TI}$ nas organizações pressupõe seis conclusões: a $\mathrm{TI}$ viabiliza importantes mudanças nos processos de trabalho; a TI integra negócios dentro e fora das organizações; a TI é a causadora de mudanças no ambiente competitivo de muitas indústrias, a TI proporciona novas oportunidades estratégicas para as organizações obrigando-as a uma reavaliação de sua missão e operações; o sucesso das aplicações de TI exige alterações na gestão empresarial e na estrutura organizacional; para que prosperem no ambiente globalmente competitivo as organizações terão que realizar as transformações necessárias, sendo esse o maior desafio para os seus gestores.

Nesse sentido as empresas necessitam de um Planejamento Estratégico da Tecnologia da Informação (PETI) para auxiliar o Planejamento Estratégico do Negócio (PEN), na identificação das oportunidades e como forma de apoiar os negócios empresariais (FREITAS, 2007).

O PETI tem sido considerado fundamental e necessário para direcionar e gerenciar todos os recursos de $\mathrm{TI}$, tais como pessoas, aplicações, informação e infraestrutura, estando alinhado às prioridades e às estratégias de negócio (ITGI, 2005), além de ter impacto direto na implantação da Governança de TI nas organizações.

Nesse sentido, o PETI, que tem também recebido destaque pela área de Governança de $\mathrm{TI}$, na qual é considerado como primeiro processo entre outros existentes (ITGI, 2007), pode contribuir na operacionalização dos fundamentos dessa área por meio da organização e da priorização de estratégias de negócio e, consequentemente, das estratégias de $\mathrm{TI}$.

A área de Tecnologia da Informação nas organizações, assim como as suas demais áreas, demanda recursos e esforços que exigem um planejamento 
prévio de todas as suas ações. Para essa área, a principal peça do seu planejamento é o planejamento estratégico de TI PETI (FOINA, 2001).

Das áreas da TI, o PETI é uma das mais carentes, uma vez que os tópicos mais diretamente relacionados e que o afetam estão entre as suas primeiras preocupações. Por outro lado, o PETI é um tópico central na área de gestão de TI quer pela sua perspectiva estratégica, quer pela sua visão tradicional, sendo apontado pelos responsáveis por essa atividade como um dos aspectos críticos. Por esse motivo, deve ser considerado merecedor de melhor atenção por parte dos investigadores dessa área de conhecimento (AMARAL e VAREJÃO, 2007).

O PETI tem sido considerado como a determinação de oportunidades estratégicas, objetivos, fatores críticos de sucesso e a informação necessária de diferentes partes da organização (MARTIN, 1989).

Galliers (1987) define PETI como uma tarefa de gestão na qual se lida com considerações como integração dos sistemas de informação aos processos de planejamento corporativo, decisões de aquisições de recursos de Tecnologia da Informação, processos de desenvolvimento de aplicações, entre outros.

Segundo Ward, Griffiths e Whitmore (1996), o PETI também considera os aspectos organizacionais da gestão de TI por toda a organização. Esse também é o entendimento de Rezende (2002), que defende que o PETI oferece uma visão sistêmica de conceitos, modelos, métodos e recursos de $\mathrm{TI}$, necessária para facilitar à estratégia do negócio e dar suporte as decisões, as ações empresariais e aos processos da organização, resultando em benefícios ao negócio a curto, médio e longo prazo.

De acordo com Boar (2002), o PETI pode ser definido como um processo que permite aprimorar a TI usando-a de modo inteligente. A TI pode aprimorar vastamente a sua qualidade, eficiência, efetividade e seu intempestivo esforço.

Segundo Rezende e Abreu (2002), o PETI é um processo dinâmico e interativo para estruturar estratégica, tática e operacionalmente (i) as informações organizacionais, (ii) a TI, (iii) os sistemas de informação, (iv) as pessoas envolvidas e (v) a infraestrutura necessária para o atendimento de todas as decisões, ações e respectivos processos da organização.

A construção ou a implantação do planejamento estratégico nas organizações atuais deve acontecer de forma mais evoluída, evitando uma elaboração estática, analítica e extremamente formal, pois se torna necessário um 
maior dinamismo nesse ambiente turbulento, mutável e competitivo. O dinamismo e a interação dos planos de ações que compõem o planejamento estratégico possibilitam a implantação da chamada gestão estratégica da organização (ANSOFF; McDONNELL, 1984; PORTER, 1991; MINTZBERG; QUINN, 2001; FECHIO, 2001).

Esse caráter dinâmico do PETI decorre do ambiente instável onde se desenvolvem as estratégias de TI. Dessa forma, essas estratégias devem ser constantemente ajustadas para que possam refletir novas condições de negócios e de mercado, assim como questões referentes à evolução de tecnologias (LUTCHEN, 2004).

Segundo Min, Suh e Kim (1999), para uma organização desenvolver o plano estratégico, ela necessita responder às seguintes questões:

1) Qual a posição ou o status da organização no presente? (status atual)

2) Em qual posição ela planeja estar no futuro? (objetivo)

3) Qual caminho ela deverá seguir para alcançar o objetivo? (implementação)

Min, Suh e Kim (1999) consideram ainda que o PETI é o processo de responder a essas questões especificamente em relação a TI. Para esses autores, PETI é o processo de criação de um plano para implementação e uso da TI para maximizar a efetividade dos recursos da organização no intuito de alcançar os seus objetivos.

Como benefícios, o PETI acrescenta à organização um conjunto de vantagens, tais como: (i) integridade, provendo um processo compreensivo para a execução de todas as tarefas referentes a cada etapa do plano, indo desde a elaboração até a implementação; (ii) integração, proporcionando integração entre visões tecnológicas diferentes, com perspectivas múltiplas; (iii) base analítica, ultrapassando uma visão superficial do processo estratégico na área de TI; (iv) participação, propiciando a participação de todos na empresa, e não somente do pessoal da área de tecnologia; ( $v$ ) foco na qualidade, estabelecendo mecanismos para avaliar e medir a qualidade da área de TI (BOAR, 2002).

Lederer e Salmela (1996) desenvolveram um estudo teórico levantando trabalhos de décadas sobre o PETI para descrever a teoria desse planejamento. $O$ objetivo da apresentação da teoria estudada consistiu em convencionar um 
significado organizado do entendimento de planejamentos estratégicos de TI antecedentes visando estimular a pesquisa e apoiar a prática.

A teoria do PETI apresentada por esses autores pode ser visualizada graficamente na Figura 1.

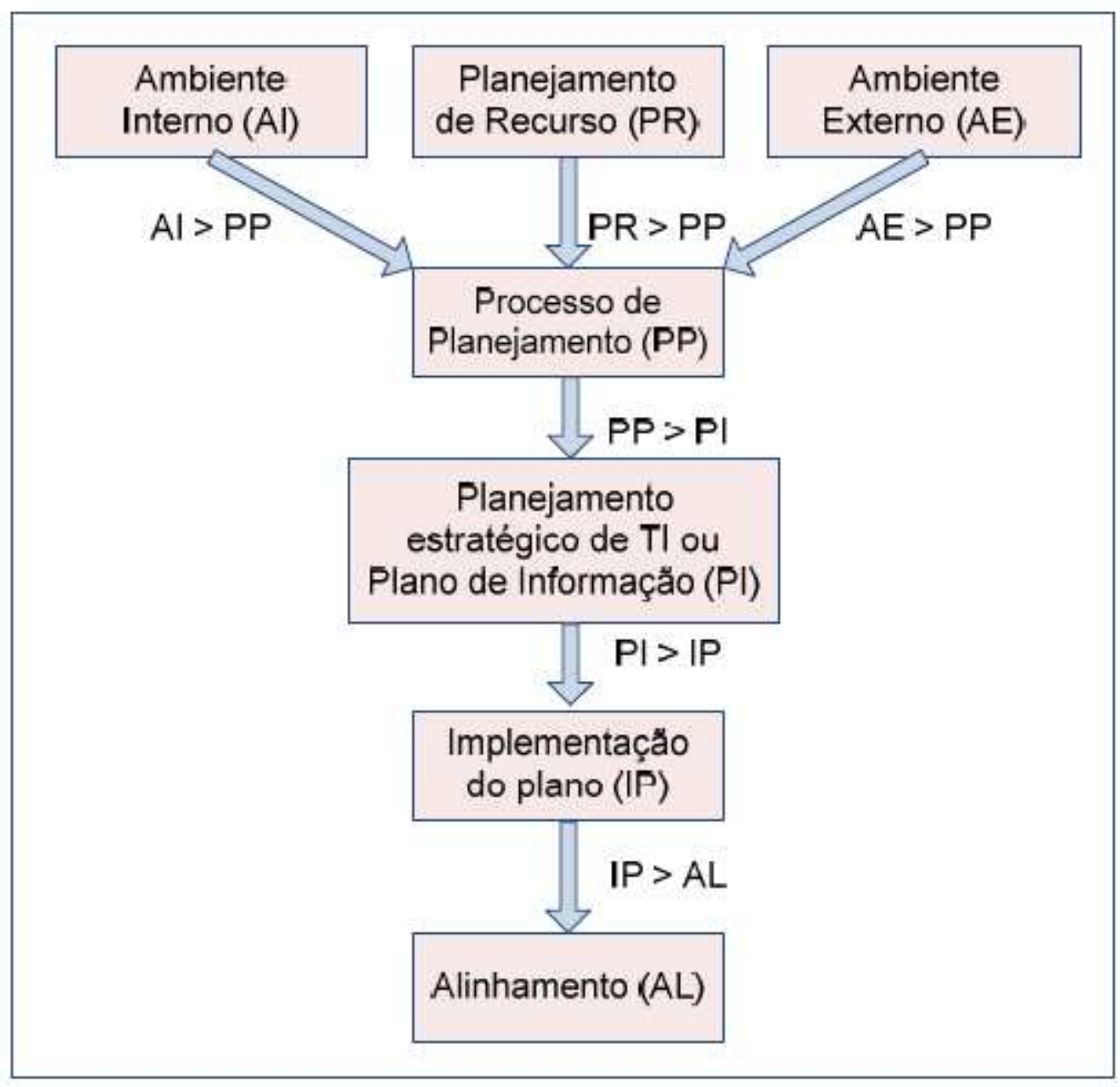

Figura 1: Teoria do Planejamento Estratégico de TI

Fonte: adaptado de Lederer e Salmela (1996, p. 240)

De acordo com Lederer e Salmela (1996, p. 241), a teoria do planejamento estratégico de TI possui sete componentes, a saber: (1) ambiente externo; (2) ambiente interno; (3) planejamento de recursos; (4) processo de planejamento; (5) plano estratégico de TI ou plano de informação; (6) implementação do plano de informação; e (7) alinhamento do plano de informação com o plano de negócio da organização. 
Conforme pode ser observado na Figura 1, são apresentadas as relações entre esses componentes, expressas na forma de setas e rótulos. Os relacionamentos representam as hipóteses da teoria sobre PETI dos autores. Pesquisas anteriores à proposta desses autores não testaram explicitamente e intencionalmente esses relacionamentos (exemplo: as setas entre os componentes), mas, por outro lado, apresentaram evidências para sugeri-las.

A seguir, de acordo com Lederer e Salmela (1996), são apresentados mais detalhes sobre esses componentes da teoria referente ao PETI.

1. Ambiente externo (AE): é formado por um conjunto de fatores que exercem influência sobre o PETI (LEDERER e SALMELA, 1996). Esses fatores (representados na Figura 1 pelo rótulo "AE > PP"), que podem influenciar 0 "Processo de Planejamento", podem ser exemplificados como: preferências de clientes, tecnologias emergentes, legislação governamental, ações de competidores, entre outras, que podem influenciar o PETI e torná-lo mais complexo (LEDERER e MENDELOW, 1990).

Para Lederer e Salmela (1996), quanto mais mudanças ocorrerem no ambiente externo, mais instável pode se tornar o processo de planejamento. Sendo assim, um ambiente externo mais estável produz um processo de planejamento mais eficiente e efetivo.

2. Ambiente interno (Al): é considerado como um determinante para o processo de PETI. Os elementos do ambiente interno (representados na figura com o rótulo "Al" > "PP") podem ser exemplificados como: estilo de planejamento e controle da organização, tamanho da organização, estrutura organizacional, estrutura da TI (centralizada ou descentralizada, por exemplo), assim como o estilo de gestão (exemplo mais conservador) (LEDERER e SALMELA, 1996). Metas e objetivos de informação e de TI também são elementos do ambiente interno, assim como ganho de vantagem competitiva, identificação de aplicações mais lucrativas, identificação de aplicações estratégicas, aumento do comprometimento da alta direção, melhoria da comunicação com os usuários, entre outros (GALLIERS, 1987).

Para Lederer e Salmela (1996), esses elementos podem influenciar também o processo de planejamento, como, por exemplo, a cultura da organização pode facilitar o desenvolvimento do planejamento estratégico de TI, uma vez que a organização seja congruente com ele. Dessa forma, um ambiente interno mais simples produz um processo de planejamento mais eficiente e efetivo. 
3. Planejamento de recursos (PR): o maior recurso necessário para desenvolvimento do PETI é o tempo e o esforço de gerentes e de outros profissionais que participam dele. A presença dessas pessoas tem um efeito favorável sobre o PETI (PR > PP) (REPONEN, 1994). Embora, quando há um maior envolvimento da alta direção no desenvolvimento do PETI, consequentemente há uma maior probabilidade de ele ser mais bem-sucedido, a participação desses colaboradores da organização, assim como de gerentes e outros colaboradores não é suficiente. As habilidades e as experiências também são importantes para PETls bem-sucedidos (VITALE, IVES e BEATH, 1986).

Outro importante recurso para o PETI é o plano de negócio da organização.

Dessa forma, uma vez que o planejamento de recurso seja maior e mais extensivo, produzirá um processo de planejamento mais eficiente e efetivo (LEDERER e SALMELA, 1996).

4. Planejamento de processo (PP): um processo típico de PETI segue uma série de passos bem definidos. Todavia, esse processo pode diferenciar substancialmente de uma organização para outra. No PETI, algumas organizações podem escolher para selecionar ou omitir alguns passos ou tarefas em particular.

Outras organizações podem escolher enfatizar determinados passos ou tarefas para aplicar recursos mais diligentemente que outros. Há organizações que podem optar por completar o estudo do plano mais rapidamente do que outras. Essas escolhas determinam o plano estratégico de TI ou plano de informação ("PP > PI"). Alguns consultores fornecem suporte para os seus próprios processos recomendados. Um processo consiste em um conjunto de passos chamado de método para PETI (LEDERER e SALMELA, 1996).

Atividades típicas que são compostas de métodos para PETI são: reuniões, entrevistas e análise de documentações. Adicionalmente, são realizadas nas organizações atividades em equipe, leituras e relatórios por especialistas (EARL, 1990). Como resultado desses métodos, os planejadores de PETI elaboram um extensivo texto assim como uma variedade de tabelas, diagramas e gráficos.

Ainda muitos planejadores de PETI preparam um conjunto de orientações sobre como desenvolver determinadas tarefas e assim desempenhar mais efetivamente o PETI (BOWMAN, DAVIS e WETHERBE, 1983). Posteriormente, 
neste trabalho serão contempladas características específicas de alguns métodos evidentes na área e selecionados na realização da pesquisa.

Para Lederer e Salmela (1996), não é de se surpreender que um processo de planejamento de qualidade produz um PETI com maior qualidade. Do mesmo modo, uma atenção insuficiente a essas atividades pode acarretar soluções técnicas para problemas de negócio errados. Em geral, tem-se observado que uma abordagem mais compreensível produz um plano mais usável.

5. Plano estratégico de $\mathrm{TI}$ ou plano de informação (PI): o resultado do componente "planejamento de processo" é o plano de informação (PI) ou plano estratégico de $\mathrm{TI}$, como é também chamado. O conteúdo desse plano varia de acordo com o processo utilizado durante o planejamento "PP > Pl". Com isso, um método ou processo de PETI mais limitado pode restringir os resultados a serem alcançados no plano (LEDERER e SALMELA, 1996).

De acordo com Lederer e Gardiner (1992), um plano estratégico de TI tipicamente inclui informação organizacional, de negócio, competitiva e técnicas sobre os recursos de $\mathrm{TI}$ atuais e a estratégia recomendada para a TI. Isso inclui também a explicação sobre a análise e os argumentos acerca das suas recomendações. Nenhuma das seções de um plano é menos importante, mas seções que foquem a gestão de mudanças (exemplo, como evitar resistências) têm se tornado altamente importantes.

6. Implementação do plano (IP): o plano afeta a implementação de suas recomendações ("PI > IP"). As organizações têm frequentemente falhado na implementação de seus planos, e isso tem sido considerado por elas como um sério problema (EARL, 1993). Assim, a implementação de um número grande de projetos (resultantes do plano) é um retorno desejável do PETI (RAGHUNATHAN e KING, 1988).

Conforme Boar (2002, p. 304), a implementação do PETI em uma organização consiste em um processo de quatro passos: (1) avaliação; (2) projeto ou desenho (design); (3) preparação; e (4) execução. Mecanismos de implementação, tal como um plano de recursos para implementação do projeto, e sistemas para monitoramento da implementação do plano, assim como a participação da alta direção e dos usuários no monitoramento, contribuem para as chances de sucesso e de implementação do plano (PREMKUMAR e KING, 1994, p. 90). A extensão ou o escopo da implementação de um plano são indicados pela 
existência clara de metas para os projetos, pelo progresso da avaliação e do aceite formal, e pela suficiência de recursos alocados para alcançar os objetivos do projeto (RAGHUNATHAN e KING, 1988, p. 87).

A clareza e a análise da apresentação do plano também podem aumentar as chances de adoção de um número maior de suas recomendações. Sendo assim, de acordo com Lederer e Salmela (1996), um plano mais usável produz uma maior implementação do plano ou chances maiores de sucesso nas implementações.

7. Alinhamento do plano estratégico de TI com o plano de negócio da organização (AL): o propósito da TI assim como do PETI é afetar favoravelmente a organização. Um indicador de quanto o plano tem sido favorável é a adequação ou o alcance dos objetivos da organização com a sua implementação (LEDERER e SALMELA, 1996). Isso se verificará melhor no tópico a seguir.

\subsection{Alinhamento entre o PETI e o PEE}

Para a consecução dos objetivos definidos neste estudo, será importante buscar o entendimento sobre alinhamento estratégico.

O conceito de alinhamento estratégico que tem sido apresentado por alguns estudiosos sobre o assunto e, apesar das diferenças, os mais significativos dizem que o alinhamento estratégico pode ser entendido como uma adequação de estratégias a serem implementadas entre ambientes interno e externo á organização de forma a obter uma "integração funcional" em seu sistema (HENDERSON e VENKATRAMAN, 1993).

Ao tratar da adoção do instrumento de Tecnologia da Informação, a organização que visar alcançar desenvolvimento a partir de sua implementação terá que apresentar características norteadas por estudo e planejamento adequado a cada realidade e propósitos. Visto que se torna difícil a execução coerente de atividades com base em implantação de uma tecnologia incoerente a realidade da organização. Assim um projeto elaborado para determinado local não pode ser considerado apto a atender a demanda de outro lugar. Para perfeita aplicação o 
projeto e seu alinhamento precisam estar em conformidade com cada ambiente (ALBERTIN, 2001).

Segundo Kerzner (1995) apud Albertin (2001) para que os projetos elaborados para implantação de Tecnologia da Informação em determinado setor tenham sucesso, é necessário que se identifique com o ambiente. Sendo assim é essencial que os mesmos sejam personalizados e geralmente temporários visto que os processos de trabalho, especialmente no setor judiciário bem como as demandas dos processos, não são estáticos e sim em dinâmica transformação.

Por consumir considerável parcela de recursos: físico, financeiros, humanos e materiais, segundo Castro (2004) é pertinente que sejam feitas escolhas coerentes para sua aplicação, porque assim aparecerão resultados eficientes no que tange aspectos de caráter operacional e estratégico.

De acordo com Henderson e Venkatraman (1993), em geral a falta de habilidade e perspicácia para elaboração dos projetos é que influenciam negativamente em sua viabilidade. Por esse motivo é necessário atentar para a coordenação do projeto e alinhamento das estratégias que precisam ser traçadas seja para o negócio ou para as atividades no setor público. De acordo com esses autores trata-se de ajustes ao traçar as estratégias de ação para a aplicação da Tecnologia da Informação que deve ser vista como processo dinâmico com aspecto de continuidade.

Nessa perspectiva por sua característica de processo dinâmico e contínuo, a aplicação da Tecnologia da Informação não pode ser considera uma ação isolada, ela ocorre em interação com setores internos e externos.

O uso eficaz da TI e a integração entre sua estratégia e a estratégia do negócio vão além da ideia de ferramenta de produtividade, sendo muitas vezes fator crítico de sucesso. Hoje, o caminho para este sucesso não está mais relacionado somente com o hardware e o software utilizados, ou ainda com metodologias de desenvolvimento, mas com o alinhamento da TI com a estratégia e as características da empresa e de sua estrutura organizacional (LAURINDO et al, 2001).

Nessa linha, Boar (2002) considera como uma das questões mais importantes para os executivos a busca da sinergia entre estratégia de negócios e de $\mathrm{TI}$, considerando a relevância da estratégia para as organizações e o papel estratégico da TI para a alavancagem de vantagens competitivas. 
A ideia de Alinhamento Estratégico envolve a ligação e coerência entre a estratégia organizacional e a estratégia de TI (SACCOL, 2005).

O alinhamento estratégico entre o PETI e o PEE, por conta da sua relevância como otimizador do desempenho global da empresa, permite o equilíbrio necessário entre as funções consideradas cruciais para atingir o sucesso organizacional (FREITAS, 2007, p.23).

Rezende (2002) observa que o alinhamento entre a TI e os negócios, de forma resumida, analisa a relação estratégica entre as funções de tecnologia da informação e os objetivos do negócio. Todavia, o estágio de alinhamento verificado nas organizações é dependente de vários fatores, entre eles o conhecimento do assunto pela gestão, a infraestrutura e a cultura organizacionais, a tecnologia utilizada, a natureza do negócio e a habilidade da organização em administrar mudanças.

Na visão de Graeml (2000) o conjunto de estratégias para os sistemas de informação deve ser consequência das estratégias da organização. Quando a área de $\mathrm{TI}$ e as demais áreas trabalham de forma colaborativa, tende a aumentar o valor agregado ao negócio. A TI passa a ter uma melhor percepção das necessidades empresariais e atua com mais participação e sinergia, colaborando na criação de valor. O entrosamento entre a área de informática e as demais áreas da empresa proporciona o alinhamento da TI com o negócio da empresa, conforme aumenta a confiança da organização na contribuição da TI para agregação de valor aos serviços e produtos da empresa.

Graeml (2000, p.114) conclui ainda:

O alinhamento da $\mathrm{TI}$ com o negócio da empresa ocorre à medida que a tecnologia da informação passa a assumir o papel de suporte estratégico para o atingimento dos objetivos organizacionais, decorrente do entendimento, por parte dos profissionais de informática, da natureza das mudanças exigidas da organização.

Dessa forma Laurindo et al (2001) salienta dois aspectos igualmente importantes no processo de alinhamento estratégico, trata-se da eficiência e da eficácia aplicada a Tecnologia da Informação: 
De maneira geral, eficiência significa fazer bem as coisas, enquanto que eficácia significa fazer as coisas certas. A eficiência está associada ao uso dos recursos, enquanto a eficácia está associada com a satisfação de metas, objetivos e requisitos. Eficiência está relacionada com aspectos internos à atividade de TI e a adequada utilização dos recursos, enquanto que a eficácia confronta os resultados das aplicações de $\mathrm{TI}$ com os resultados no negócio da empresa e os possíveis impactos na sua operação e estrutura (LAURINDO et al, 2001, p. 5).

De acordo com King (1978), o alinhamento é o nível de quanto o plano estratégico de TI reflete o plano de negócio da organização. Ele pode ser medido com o número ou a qualidade das recomendações implementadas do PETI, os quais também refletem o plano de negócio da organização.

Para Lederer e Salmela (1996), o alinhamento pode ser visto como o grau no qual o processo de planejamento resulta no plano estratégico de TI. De acordo com Raghunathan e Raghunathan (1994), o alinhamento representa o cumprimento ou a realização dos objetivos. Essa última tem sido usada para medir a efetividade do PETI. Embora o alinhamento seja um fator preferido para medi-la, outros fatores podem ser levantados em conta, como: vantagem competitiva obtida com o impacto na organização pelo plano, melhoria de produtividade, aumento de vendas, redução de custos e/ou aumento de lucro, assim como a satisfação dos desenvolvedores do PETI (WISEMAN, 1985).

Dessa forma, Lederer e Salmela (1996) concluem que uma maior implementação produz um melhor alinhamento. Concluindo, a teoria sobre PETI de Lederer e Salmela (1996) apresenta um conjunto de componentes que representam a teoria do planejamento estratégico de TI. Desenvolvido com o intuito de estimular a pesquisa e apoiar a prática em PETI, esse estudo demonstrou que todos os componentes exercem uma atuação forte na efetividade do PETI. Outra consideração é a de que quanto mais fiel for o plano aos objetivos da organização, mais planejado ele estará e permitirá também a execução de testes, favorecendo a identificação de soluções paliativas caso sejam necessárias. 
Sendo assim, não basta que haja uma estratégia de TI; ela deve estar em alinhamento com a estratégia de negócio da empresa ou instituição que lança mão de seu uso. 


\section{MÉTOdOS E TÉCNICAS DE PESQUISA}

O objetivo essencial da ciência é a proximidade à veracidade dos fatos, sendo que, para um conhecimento ser considerado cientifico, é necessário determinar o método que possibilitou se chegar a esse conhecimento. De acordo com Gil (1999, p.29), o método científico "é um conjunto de procedimentos intelectuais e técnicos adotados para se atingir o conhecimento".

A metodologia da pesquisa num planejamento deve ser entendida como 0 conjunto detalhado e sequencial de métodos e técnicas científicas a serem executados ao longo da pesquisa, de tal modo que se consiga atingir os objetivos inicialmente propostos e, ao mesmo tempo, atender aos critérios de menor custo, maior rapidez, maior eficácia e mais confiabilidade de informação (BARRETO e HONORATO, 1998).

Esta pesquisa terá como objetivo a aplicação prática do modelo de Rezende (2008, p. 114), com a elaboração de instrumento de coleta de dados baseado nas variáveis que compõem os recursos sustentadores do alinhamento estratégico, segundo o escopo do modelo. Será realizado um estudo de caso que permitirá $\circ$ aprofundamento no tema proposto para o trabalho, dentro de uma condição contextual particular de uma organização, cuja análise de dados possa refletir um diagnóstico que indique o nível de integração da tecnologia da informação aos negócios ou serviços organizacionais.

\subsection{Tipo e descrição geral da pesquisa}

Esta pesquisa se caracterizará como descritiva com abordagem quantiqualitativa. A pesquisa descritiva procura conhecer a realidade estudada, suas características, seus problemas. Pretende "descrever com exatidão os fatos e fenômenos de determinada realidade" (TRAVIÑOS, 1987, p.100). 
O método selecionado será o de estudo de caso que, de acordo com Traviños (1987, p.110), este tipo de abordagem metodológica objetiva “... aprofundar o estudo e a descrição de determinada realidade".

O modelo adotado será o proposto por Rezende (2008, p. 114) que, segundo o autor, pode ser sustentado principalmente por quatro grandes grupos de fatores ou recursos sustentadores: tecnologia da informação (TI); sistemas de informação e do conhecimento (SI); pessoas ou recursos humanos $(\mathrm{RH})$; e contexto organizacional (CO).

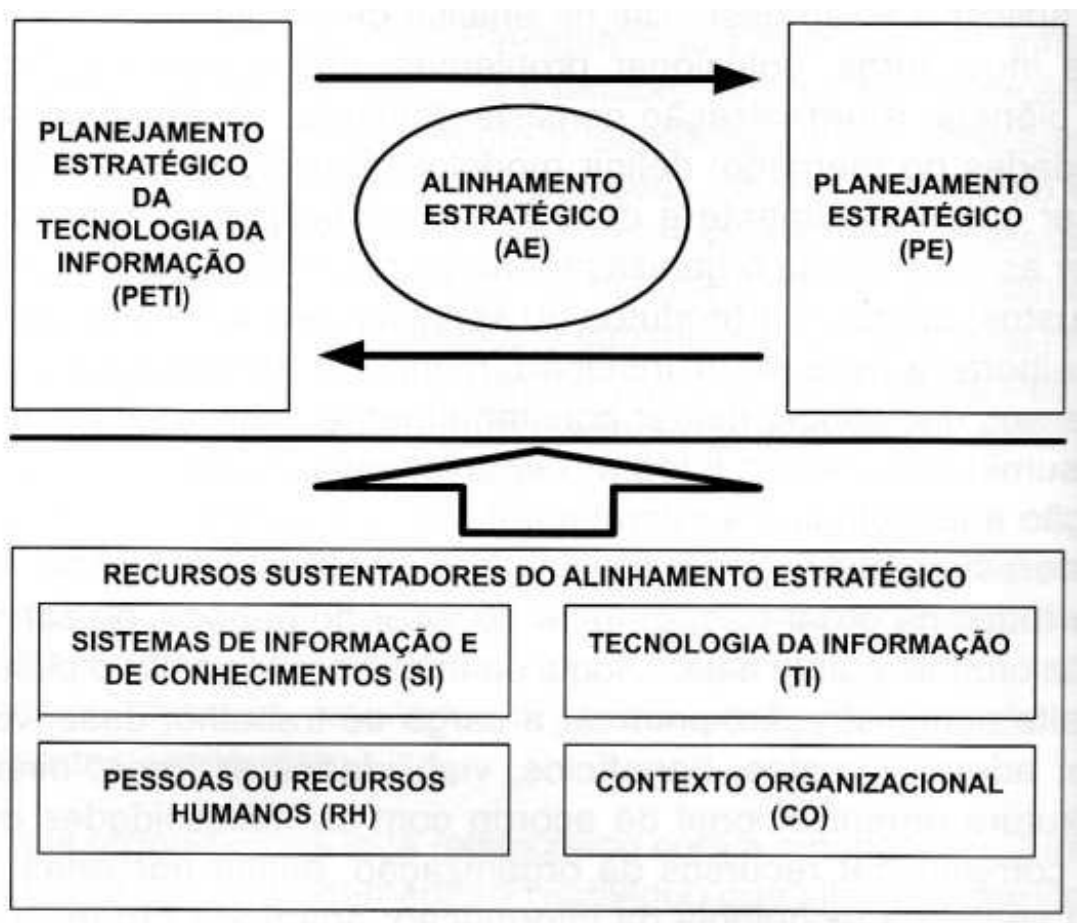

Figura 2: Modelo proposto por Rezende (2008, p. 114)

Fonte: Rezende (2008, p. 114)

Pelo desenho apresentado, verifica-se que o alinhamento estratégico entre o PETI e o PEE ocorre quando é suportado pelos recursos sustentadores: tecnologia da informação, sistemas de informação e do conhecimento, pessoas ou recursos humanos e contexto organizacional. Ainda segundo Rezende, nesse modelo não são levadas em conta as ameaças, oportunidades e outras variáveis externas, assim como se os planejamentos ou as técnicas de gestão organizacional utilizadas são efetivas na organização, já que o objetivo está voltado para os recursos que sustentam a integração da tecnologia da informação aos negócios. 
O modelo proposto para ser implementado deverá ter seus esforços canalizados em três dimensões: Planejamento Estratégico da Tecnologia da Informação (PETI) e de seus recursos e ferramentas; Planejamento Estratégico (PE) e de seus negócios ou serviços organizacionais; e recursos sustentadores do alinhamento estratégico (AE) (REZENDE 2008, p. 115).

As dimensões do modelo estão desmembradas em construtos que compreendem cinco partes: tecnologia da informação; sistemas de informação e sistemas de conhecimentos; pessoas ou recursos humanos; contexto organizacional ou infraestrutura organizacional; e alinhamento estratégico entre PETI e PE. As variáveis que formam cada construto dão sustentação ao alinhamento estratégico.

A dimensão do Planejamento Estratégico da Tecnologia da Informação (PETI) fornece a visão geral de conceitos, modelos, métodos e ferramentas de sistemas de informação e tecnologia da informação necessários para facilitar a estratégia de negócios. A dimensão do Planejamento Estratégico (PE) fornece uma visão geral de conceitos, modelos, métodos e instrumentos de como fazer acontecer a estratégia de negócios. A dimensão dos recursos sustentadores do alinhamento estratégico fornece uma visão geral das atividades, variáveis e fatores que facilitam o alinhamento estratégico.

A relação dos construtos propostos por Rezende e suas respectivas variáveis estão representadas na tabela 1.

Tabela 1

Relação dos Construtos segundo o Modelo de Rezende

\begin{tabular}{c|l}
\hline \multicolumn{1}{|c}{ CONSTRUTO } & \multicolumn{1}{|c}{ VARIÁVEIS } \\
\hline Alinhamento Estratégico (AE) & - sinergia das funções organizacionais \\
-adequação das tecnologias \\
disponíveis \\
- gestão do PETI \\
- inteligência competitiva e inteligência \\
organizacional
\end{tabular}




\begin{tabular}{|c|c|}
\hline & - sistemas de conhecimentos \\
\hline Tecnologia da Informação (TI) & $\begin{array}{l}\text { - hardware } \\
\text { - software } \\
\text { - sistemas de telecomunicação } \\
\text { - gestão de dados e informação }\end{array}$ \\
\hline Pessoas ou Recursos Humanos $(\mathrm{RH})$ & $\begin{array}{l}\text { - valores e comportamentos } \\
\text { - perfil profissional } \\
\text { - competências e capacitação } \\
\text { - plano de trabalho } \\
\text { - planejamento informal participativo } \\
\text { - comunicação e relação } \\
\text { - multiequipe e parcerias } \\
\text { - clima, ambiente e motivação } \\
\text { - vontade e comprometimento } \\
\text { - consciência e participação efetiva }\end{array}$ \\
\hline $\begin{array}{c}\text { Contexto Organizacional ou } \\
\text { Infraestrutura Organizacional (CO) }\end{array}$ & $\begin{array}{l}\text { - imagem institucional } \\
\text { - domínio do negócio ou serviços e } \\
\text { preocupação com resultados } \\
\text { - missão, objetivos e estratégias } \\
\text { - modelos decisórios } \\
\text { - processos e procedimentos } \\
\text { - metodologia ou processo formal de } \\
\text { planejamento } \\
\text { - cultura, filosofia e políticas } \\
\text { organizacionais } \\
\text { - estrutura } \\
\text { departamental } \\
\text { - investimento e custos } \\
\text { - infraestrutura organizacional }\end{array}$ \\
\hline
\end{tabular}

Fonte: Rezende (2008, p. 115) 


\subsection{Caracterização da organização, setor ou área do objeto de estudo}

A organização objeto deste trabalho é o Sicoob Confederação. O Sicoob (Sistema de Cooperativas de Crédito do Brasil) é o maior sistema cooperativo de crédito do País com mais de 1,7 milhão de associados. A instituição está presente em 21 Estados e no Distrito Federal, por meio de uma rede de aproximadamente 1,7 mil pontos de atendimento.

O Sicoob Confederação surgiu com a finalidade de prestar serviços de representação, supervisão, padronização de procedimentos operacionais, implantação de sistema de controle interno e de informações gerenciais, capacitação, coordenação do uso da marca Sicoob, apoio ao planejamento estratégico das cooperativas centrais de crédito, assessoria jurídica e de gestão operacional do Fundo Garantidor do Sicoob (FGS).

A confederação atua junto às cooperativas centrais de crédito, no sentido de uniformizar os serviços prestados aos associados das cooperativas singulares e contribuir para a consolidação de padrão de qualidade homogêneo em todo o sistema. Têm por meta o cumprimento de sua missão que é: "contribuir para a consolidação do Sicoob como sistema cooperativo de crédito sólido, solidário e autossustentado, visando benefícios financeiros e sociais aos cooperados e suas comunidades".

O Sicoob Confederação possui sede própria em Brasília, no Setor de Indústrias Gráficas no mesmo prédio onde funciona o Bancoob (Banco Cooperativo do Brasil), instituição financeira privada, sociedade anônima de capital fechado, cujo controle acionário pertence às 14 cooperativas centrais de crédito. Atualmente conta com cerca de 500 colaboradores entre funcionários da própria organização e terceirizados, sendo que $80 \%$ deste contingente estão alocados na Diretoria de Tecnologia da Informação. 


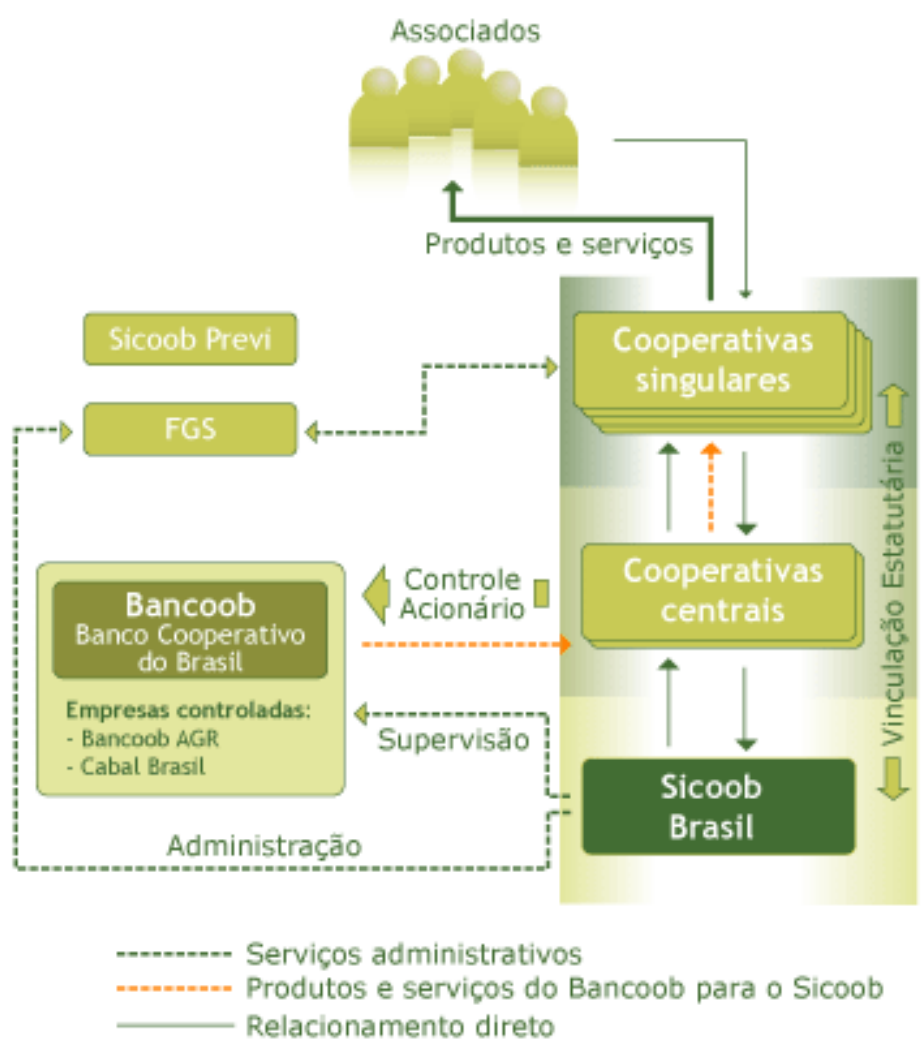

Figura 3: Modelo Organizacional do Sicoob

Fonte: Portal do Sicoob Confederação

O Sicoob Confederação possui uma estrutura de TI responsável pelo desenvolvimento, processamento e manutenção dos sistemas de negócios das cooperativas, das centrais e do Bancoob. Além do pessoal alocado para os serviços de desenvolvimento de aplicações, processamento de serviços e suporte técnico, a área de $\mathrm{Tl}$ é responsável pela infraestrutura e manutenção de dois Data Centers que funcionam de modo distribuído e contingenciado.

Como a grande maioria das instituições financeiras do Brasil, o Sicoob Confederação tem os seus sistemas de negócios fortemente apoiados pela TI.

\subsection{Metodologia de formulação do PEE do Sicoob}

O passo inicial empreendido pelo Sicoob Confederação rumo à elaboração de seu primeiro Planejamento Estratégico Empresarial integrado, compreendeu a capacitação de um grupo de funcionários, da própria Confederação e das Centrais, 
com foco na promoção do planejamento estratégico participativo orientado por objetivos - marco lógico, tendo como base o método ZOPP. A sigla ZOPP significa ZIEL - Objetivos, ORIENTIERTE - Orientados, PROJEKT - Projetos e PLANUNG Planejamento. O ZOPP é um sistema que compreende:

- procedimentos e instrumentos para o planejamento de projetos orientado para os objetivos;

- definição de objetivos de longo prazo, claros e realistas;

- melhoria da comunicação e a cooperação entre projeto, central e organização

- do parceiro através do planejamento conjunto e de clara documentação/claras definições;

- determinação da área de responsabilidade da equipe do projeto; e

- servir de base à monitoração e avaliação.

Dessa forma era esperado que os participantes pudessem, ao final do treinamento:

- Na área de conhecimento, ter ampliado seus conhecimentos sobre planejamento estratégico participativo, suas diferentes etapas, instrumentos, aplicações e gerenciamento;

- Na área de habilidade, ser capazes de aplicar os instrumentos de planejamento estratégico orientado por objetivos e de coordenação de grupos de trabalho; e

- Na área de comportamento, ter assimilado atitudes condizentes com um processo participativo de trabalho com grupo e em equipes.

Após a fase de treinamento, deu-se o início dos trabalhos de concepção do primeiro planejamento estratégico empresarial integrado, com a participação das Centrais e da Confederação. Foi estabelecido um marco lógico que serviria de roteiro para o direcionamento das etapas da gestão estratégica, abaixo listadas:

- Pressupostos externos; 
- Análise da situação;

- Definição da visão;

- Definição da missão;

- Definição dos objetivos estratégicos - Balanced Scorecard (BSC);

- Definição das ações estratégicas - projetos estratégicos;

- Definição da proposta para gestão do planejamento estratégico;

- Definição da metodologia para gerenciamento do portfólio de projetos;

- Seleção dos projetos prioritários;

- Construção do plano operacional para cada projeto prioritário;

- Determinação dos indicadores de desempenho.

Como resultado da análise da situação do Sicoob foi possível um olhar objetivo das forças que compõem o negócio da organização, de forma a permitir o desenvolvimento da estratégia empresarial como demonstrado na Tabela 2.

Tabela 2

Forças que Compõem o Negócio da Organização

\begin{tabular}{c|cc}
\hline \multicolumn{3}{c}{ Ambiente Interno } \\
\hline Pontos fortes: 24 & Pontos fracos: 21 \\
\hline \multicolumn{3}{c}{ Ambiente Externo } \\
\hline Oportunidades: 23 & Ameaças: 23
\end{tabular}

Fonte: PEE do Sicoob Confederação

A partir da construção da matriz S.W.O.T. foram elaboradas a Visão, Missão e Valores do Sistema Sicoob, conforme a Tabela 3.

Tabela 3

Visão, Missão e Valores do Sistema Sicoob

\begin{tabular}{c|l}
\hline Visão do Sistema Sicoob & $\begin{array}{l}\text { "Ser reconhecido como a principal } \\
\text { instituição financeira propulsora do } \\
\text { desenvolvimento econômico e social } \\
\text { dos associados". }\end{array}$ \\
\hline Missão do Sistema Sicoob & "Gerar soluções financeiras \\
\hline
\end{tabular}




\begin{tabular}{l|l}
\hline \multirow{2}{*}{ Valores do Sistema Sicoob } & $\begin{array}{c}\text { adequadas e sustentáveis, por meio } \\
\text { do cooperativismo, aos associados e } \\
\text { as suas comunidades". }\end{array}$ \\
\hline & $\bullet$ Transparência \\
& $\bullet$ Comprometimento \\
& - Ética \\
& $\bullet$ Solidariedade \\
& $\bullet$ Responsabilidade \\
\hline
\end{tabular}

Fonte: PEE do Sicoob Confederação

A etapa seguinte da gestão estratégica, elaboração dos objetivos estratégicos, foi apoiada na metodologia Balanced Scorecard (BSC) e resultou na montagem do Mapa Estratégico do Sicoob, conforme a figura 4.

\section{Mapa Estratégico Sicoob}

Visăo: "Ser reconhecido como a principal instituiçâo financeira propulsora do desenvolvimento econômico e social dos associados".

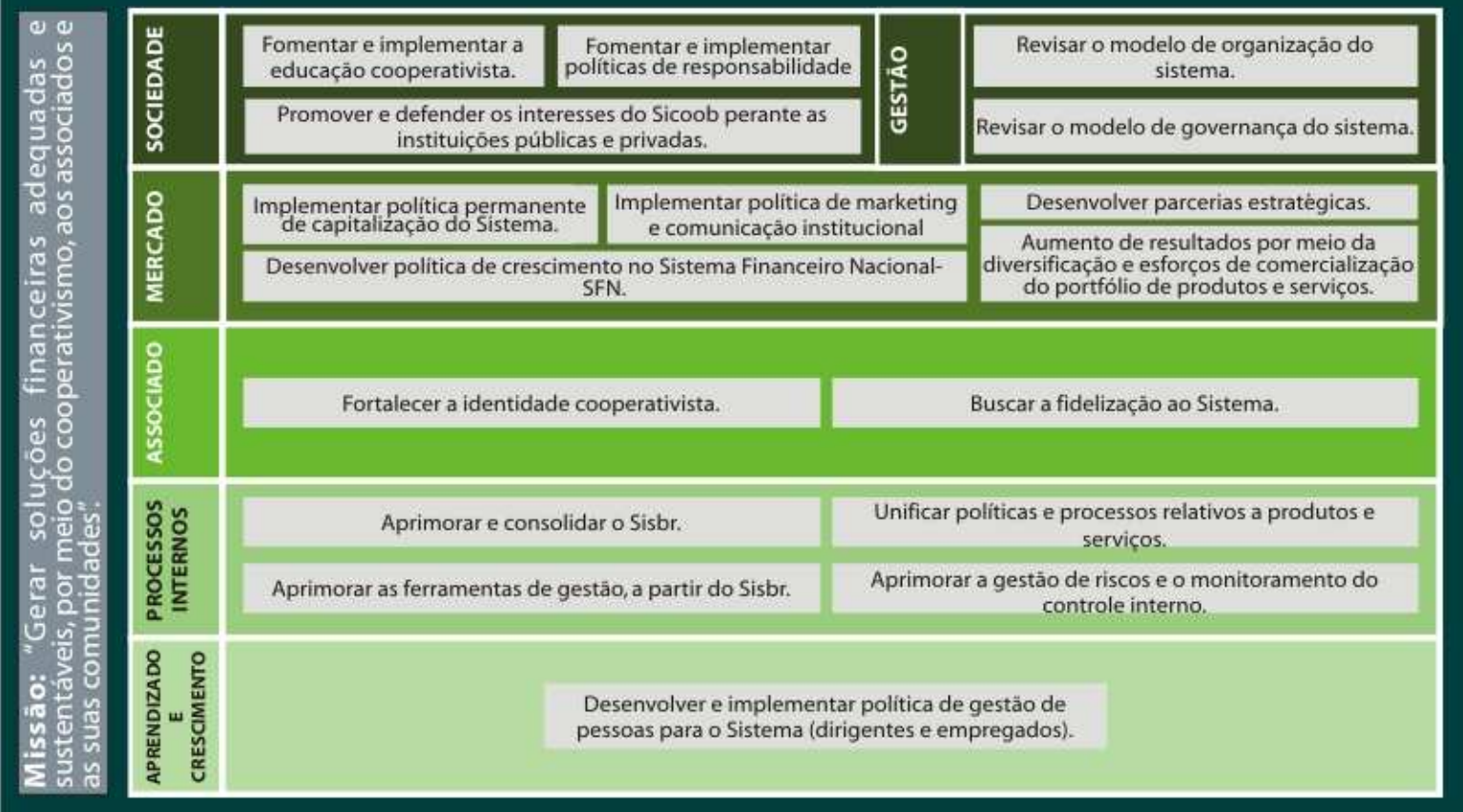

Figura 4: Mapa Estratégico do Sicoob

Fonte: PEE do Sicoob Confederação 
As fases subsequentes que dizem respeito aos planos propriamente ditos, que resultaram na definição das ações estratégicas (projetos estratégicos), da proposta para gestão do planejamento estratégico, da metodologia para gerenciamento do portfólio de projetos, seleção dos projetos prioritários, construção do plano operacional para cada projeto prioritário e a determinação dos indicadores de desempenho.

\subsection{Metodologia de formulação do PETI do Sicoob}

O Plano Estratégico de TI, PETI, tem como objetivo orientar as ações da Diretoria Executiva de TI, Direx - TI, para que, alinhadas ao Plano Estratégico do Sicoob Confederação, possam dar suporte às estratégias de negócios da organização e propiciar seu desenvolvimento e crescimento.

A formulação e implementação do PETI, planejamento este elaborado com objetivos factíveis, tanto quantitativos como qualitativos, pretende obter uma série de benefícios para o Sicoob, dentre os quais podemos citar:

- Alinhamento das estratégias de TI com as estratégias de negócio, possibilitando vantagens competitivas;

- Melhoria de desempenho da área de TI seja pela adoção mais eficaz de recursos ou pelo aumento de produtividade dos profissionais da Direx $\mathrm{Tl}$;

- Aumento dos níveis de satisfação do Bancoob, das cooperativas e associados, oferecendo tecnologia de fácil manuseio e liberando produtos competitivos com o mercado bancário;

- Vínculo dos investimentos previstos no PETI com o Planejamento Orçamentário da Direx - Tl;

- Antecipação de tendências (inovação tecnológica contínua, evitando rupturas drásticas e altos investimentos); e

- Diminuição do risco operacional do Sicoob. 
O processo planejamento estratégico de $\mathrm{Tl}$, é composto de uma metodologia e uma estrutura de apoio contendo: cronograma, reuniões, apresentações e atas dessas reuniões. Como já foram elaborados mais de uma vez, os PETI passam por revisões periódicas, normalmente baseadas em triênios e cuja metodologia para a sua elaboração e implementação seguem algumas fases, conforme a figura 5 .

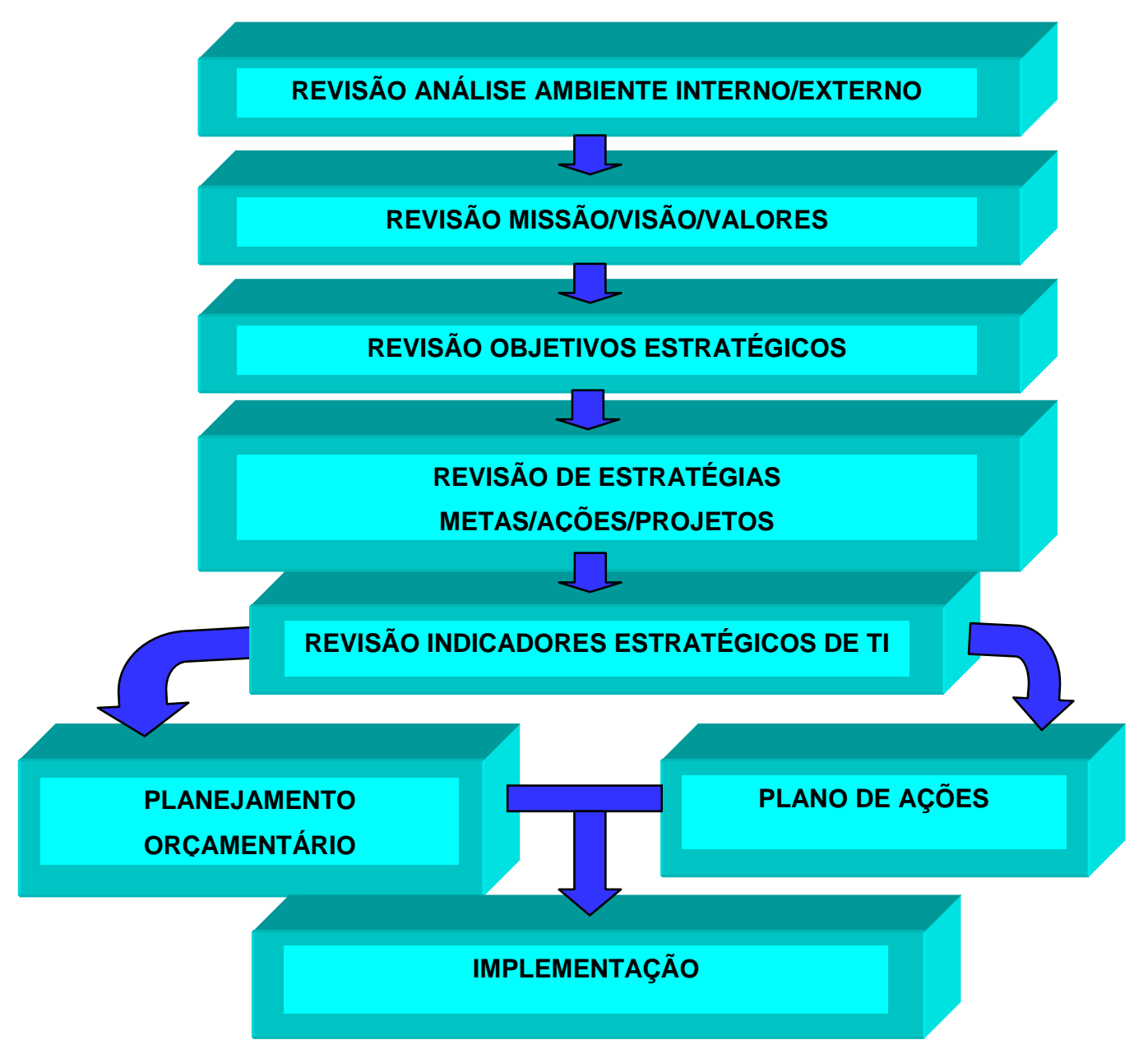

Figura 5: Fases da Elaboração do PETI do Sicoob Fonte: PETI do Sicoob Confederação

De forma mais detalhada, cada uma das fases acima está representada na Tabela 4. 
Tabela 4

Fases da Elaboração do PETI do Sicoob

\begin{tabular}{|c|c|}
\hline $\begin{array}{l}\text { Revisão e Análise do Ambiente } \\
\text { Interno e Externo }\end{array}$ & $\begin{array}{l}\text { Levantamento e análise do mercado } \\
\text { (Oportunidades e Ameaças) e da } \\
\text { instituição (Pontos Fortes e Pontos } \\
\text { Fracos) com o intuito de identificar } \\
\text { mudanças expressivas no ambiente } \\
\text { interno e/ou externo, que afetem a } \\
\text { organização quanto ao cumprimento } \\
\text { de sua missão, para possíveis e } \\
\text { necessárias correções/ajustes no } \\
\text { PETI. }\end{array}$ \\
\hline $\begin{array}{c}\text { Revisão da Missão, Visão e } \\
\text { Valores da Área de TI }\end{array}$ & 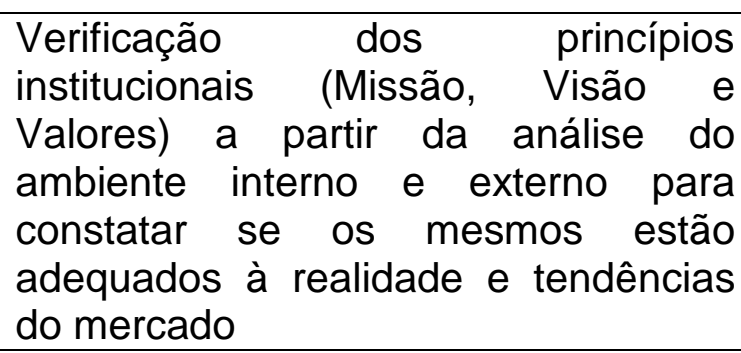 \\
\hline $\begin{array}{c}\text { Revisão dos Objetivos } \\
\text { Estratégicos de } \mathrm{TI}\end{array}$ & $\begin{array}{l}\text { Avaliação da coerência dos objetivos } \\
\text { estratégicos da área de TI e as } \\
\text { possíveis alterações do mercado e da } \\
\text { empresa identificadas na revisão e } \\
\text { análise do ambiente interno e externo. }\end{array}$ \\
\hline $\begin{array}{l}\text { Revisão de Estratégias - } \\
\text { Metas/Ações/Projetos }\end{array}$ & $\begin{array}{l}\text { Identificação dos projetos a serem } \\
\text { desenvolvidos pelas gerências e } \\
\text { vinculação desses projetos aos } \\
\text { Objetivos Estratégicos definidos no } \\
\text { PETI. Tais projetos refletem as ações } \\
\text { tomadas para se atingir cada objetivo } \\
\text { traçado. }\end{array}$ \\
\hline $\begin{array}{c}\text { Revisão dos Indicadores } \\
\text { Estratégicos de TI }\end{array}$ & $\begin{array}{l}\text { Revisão dos indicadores e métricas } \\
\text { definidas para cada objetivo } \\
\text { estratégico e sua aderência aos } \\
\text { possíveis ajustes feitos na etapa de } \\
\text { revisão dos Objetivos Estratégicos. } \\
\text { Serão revistas as fórmulas de cálculo, } \\
\text { metas e até mesmo a necessidade de } \\
\text { criação ou exclusão de indicadores. }\end{array}$ \\
\hline
\end{tabular}




\begin{tabular}{|c|c|}
\hline Planejamento Orçamentário & $\begin{array}{l}\text { O planejamento orçamentário da área } \\
\text { de TI faz parte do planejamento } \\
\text { orçamentário } \\
\text { Confederação. } \\
\text { anualmente pela Direx - TI, aprovado } \\
\text { pela Diretoria do Sicoob Confederação } \\
\text { e está sob os cuidados da área } \\
\text { orçamentária } \\
\text { Confederação. }\end{array}$ \\
\hline Plano de Ações & 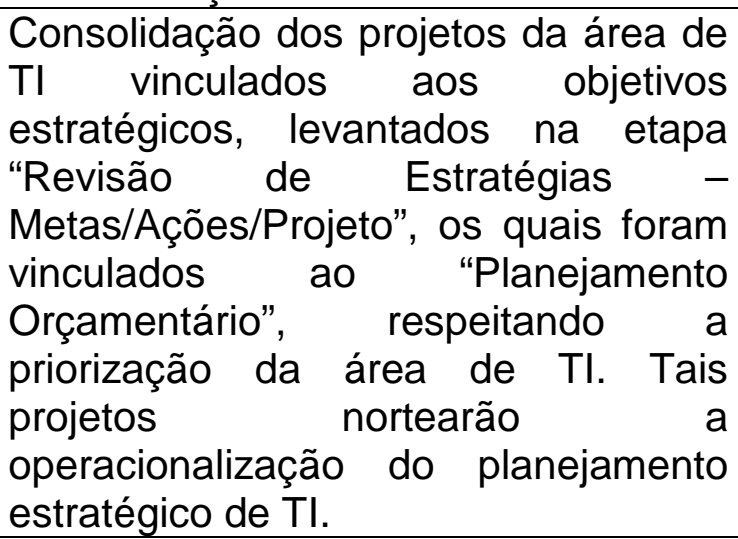 \\
\hline Implementação & $\begin{array}{l}\text { Execução dos projetos, ações, } \\
\text { procedimentos e radivides } \\
\text { necessárias para alcançar os objetivos } \\
\text { estratégicos. }\end{array}$ \\
\hline
\end{tabular}

Fonte: PETI do Sicoob Confederação

A exemplo do PEE foram definidas a missão, a visão e os valores, de acordo com o foco principal de atuação da área de TI, conforme a Tabela 5.

Tabela 5

Missão, Visão e Valores Declarados no PETI do Sicoob

\begin{tabular}{c|l}
\hline Missão da Área de TI & $\begin{array}{l}\text { Oferecer produtos e serviços de TI } \\
\text { com excelência, fomentando o } \\
\text { desenvolvimento e fortalecimento dos } \\
\text { nossos clientes. }\end{array}$ \\
\hline Visão da Área de TI & $\begin{array}{l}\text { Ser a solução de TI para o } \\
\text { Cooperativismo de Crédito Brasileiro. }\end{array}$ \\
\hline Valores da Área de TI & Compromisso com o cooperativismo \\
\hline
\end{tabular}




\begin{tabular}{l|l}
\hline de crédito do país; \\
Transparência, ética, cooperação e \\
respeito nos relacionamentos; \\
Agilidade e qualidade na prestação de \\
serviços; \\
Responsabilidade socioambiental; \\
Uso eficiente da tecnologia para \\
geração de valor ao negócio; \\
Comprometimento e motivação das \\
pessoas.
\end{tabular}

Fonte: PETI do Sicoob Confederação

$\mathrm{Na}$ etapa que trata dos objetivos estratégicos são consideradas as premissas básicas que a área de $\mathrm{Tl}$, como um todo, deve respeitar para que 0 processo estratégico tenha coerência e sustentação decisória.

Os objetivos estratégicos são de prazo longo, grande amplitude e pouca flexibilidade. No PETI os objetivos têm como premissas serem desafiantes, porém viáveis, mensuráveis e coerentes entre si.

Os objetivos estratégicos estão relacionados na Tabela 6.

Tabela 6

Objetivos Estratégicos do PETI do Sicoob

\begin{tabular}{ll|l}
\hline $\begin{array}{l}\text { OE1 - Elevar os Níveis de } \\
\text { Disponibilidade e Desempenho }\end{array}$ & $\begin{array}{l}\text { Melhorar os níveis de estabilidade, } \\
\text { disponibilidade e desempenho dos } \\
\text { produtos e serviços de TI. }\end{array}$ \\
\hline $\begin{array}{l}\text { OE2 - Fortalecer Serviços de de } \\
\text { Monitoramento }\end{array}$ & $\begin{array}{l}\text { Prover ferramentas e processos que } \\
\text { garantam o eficiente monitoramento } \\
\text { dos serviços do negócio. }\end{array}$ \\
\hline OE3 - Aprimorar a Segurança & $\begin{array}{l}\text { Melhorar os níveis de gerenciamento } \\
\text { da segurança física e lógica do } \\
\text { ambiente de TI. }\end{array}$ \\
\hline
\end{tabular}




\begin{tabular}{|c|c|}
\hline $\begin{array}{l}\text { OE4 - Evoluir a Arquitetura das } \\
\text { Soluções de TI }\end{array}$ & $\begin{array}{l}\text { Evoluir os modelos e tecnologias } \\
\text { utilizadas nos produtos de } \mathrm{TI} \text {. }\end{array}$ \\
\hline $\begin{array}{l}\text { OE5 - Desenvolver e Aperfeiçoar } \\
\text { Produtos e Serviços de TI }\end{array}$ & 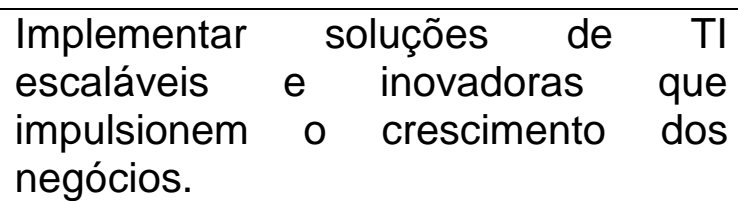 \\
\hline $\begin{array}{l}\text { OE6 - Aprimorar os Controles, } \\
\text { Otimizar os Processos e Gerenciar os } \\
\text { Riscos de TI }\end{array}$ & $\begin{array}{l}\text { Aprimorar os controles, otimizar os } \\
\text { processos e gerenciar o risco } \\
\text { operacional da área de TI, buscando } \\
\text { a excelência na qualidade dos } \\
\text { serviços prestados. }\end{array}$ \\
\hline $\begin{array}{lllr}\text { OE7 } & - & \text { Contribuir para } & 0 \\
\text { Desenvolvimento dos Profissionais de } \\
\text { TI }\end{array}$ & $\begin{array}{lll}\text { Capacitar os profissionais de } & \mathrm{TI} \text {, } \\
\text { criando oportunidades } & \text { de } \\
\text { desenvolvimento de competências. }\end{array}$ \\
\hline OE8 - Fortalecer os Relacionamentos & $\begin{array}{l}\text { Estreitar os relacionamentos da área } \\
\text { de TI e melhorar os serviços de } \\
\text { comunicação e atendimento. }\end{array}$ \\
\hline
\end{tabular}

Fonte: PETI do Sicoob Confederação

Os objetivos estratégicos do PETI devem ser mensurados por meio da construção de indicadores. A metodologia utilizada como instrumento de gestão destes indicadores é uma abordagem do BSC (Balanced Scorecard), exemplificada na figura 6. 


\section{BSC - Balanced Scorecard}

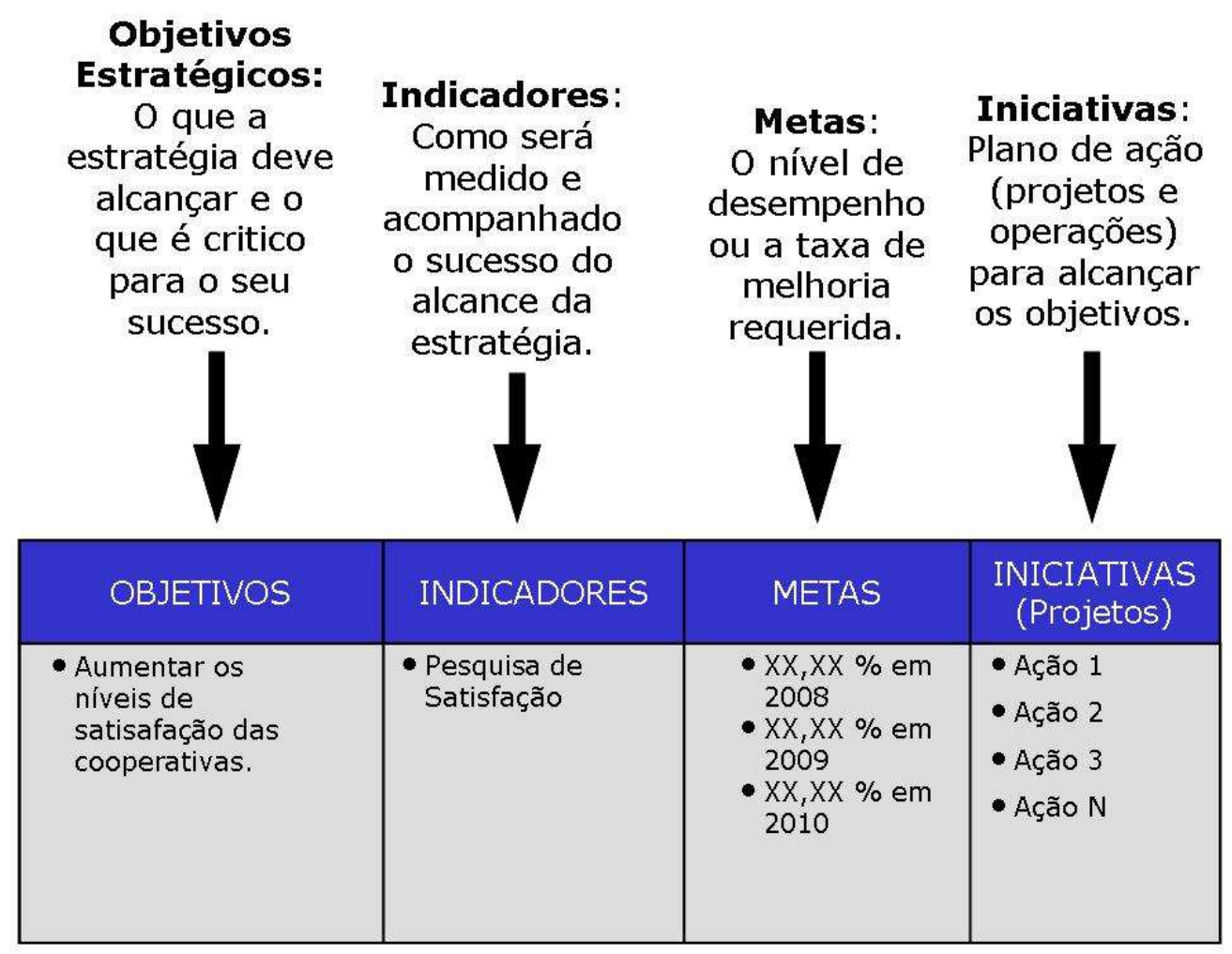

Figura 6: A Metodologia BSC na Definição dos Indicadores

Fonte: PETI do Sicoob Confederação

Os indicadores são definidos de forma direta e quantitativa, sendo a fórmula de cálculo desses indicadores elaborada a partir de critérios matemáticos e dados básicos para apuração. O BSC recomenda como regra geral utilizar pelo menos um indicador para cada objetivo estratégico. As metas devem ser quantificáveis, de alcance plausível, e representam um desafio para as equipes envolvidas.

No Plano de Ações, ou Planejamento Operacional, são relacionados todos os projetos, ações, procedimentos e atividades necessários para alcançar as metas preconizadas nos objetivos estratégicos. As descrições das tarefas ocorrem de forma detalhada e identificando:

- Nome do Projeto

- Descrição 
- Benefícios

- Área Responsável

- Previsão

- Vinculação Orçamentária

O Plano de Ações possui menor prazo, menor amplitude, porém, maior flexibilidade que o Planejamento Estratégico. Duas ações fundamentais para o sucesso do planejamento são o monitoramento constante dos indicadores e o acompanhamento efetivo dos resultados obtidos.

Todas as etapas do planejamento são avaliadas e os resultados auferidos devem servir de base para novas avaliações, retroalimentação e posterior manutenção do Planejamento Estratégico de $\mathrm{TI}$. O resultado do processo de planejamento corresponde a um documento formal que se constitui na consolidação das informações e atividades desenvolvidas no planejamento, observando a relação custo benefício das mudanças.

A comunicação é um importante instrumento para obter sucesso do planejamento, pois se os colaboradores não compreenderem a visão e a missão da área, é ainda menos provável que compreendam os objetivos estratégicos. Sem essa compreensão, os colaboradores não serão capazes de descobrir formas inovadoras para produzir os resultados necessários para o alcance das metas préestabelecidas.

A área de $\mathrm{Tl}$ encara a divulgação entre os profissionais como um programa estratégico, tão importante quanto qualquer programa de comunicação destinado ao público externo. As habilidades criativas e profissionais das equipes devem ser mobilizadas para o programa.

O programa de comunicação do PETI tem como premissas promover a compreensão da estratégia em toda área de TI, fazer com que as pessoas compartilhem a estratégia e sintam-se parte dela, capacitar a área sobre o sistema de mensuração de resultados e fornecer feedback sobre o alcance ou não das metas. São utilizados de forma contínua diversos meios de comunicação através de documentos sumarizados do Planejamento Estratégico de TI, distribuído a todos os profissionais e cooperativas do Sicoob, reuniões periódicas, planilhas, correio eletrônico corporativo e workshops. 
A elaboração do PETI conta com a participação dos superintendentes, gerentes e demais representantes das áreas de TI, viabilizando, dessa forma, a participação efetiva de todos no processo e possibilitando a construção de uma proposta sob as perspectivas estratégica e operacional.

\subsection{Participantes do estudo}

Para a realização deste trabalho será realizado um estudo de caso que compreenderá uma pesquisa junto aos gerentes e analistas de TI da Diretoria de Tecnologia da Informação do Sicoob Confederação, a respeito do alinhamento entre o planejamento estratégico de negócio e o planejamento estratégico de $\mathrm{TI}$ da organização.

A partir do modelo de Rezende (2008, p. 114), escolhido como base para esta pesquisa, será elaborado um questionário, a ser submetido aos executivos de nível gerencial e a alguns analistas da área de Ti do Sicoob Confederação, onde serão focadas as variáveis estabelecidas no modelo de Rezende, para que o estudo de caso trabalhe com evidência qualitativa e quantitativa.

A escolha dos executivos de $\mathrm{TI}$ como participantes da pesquisa deve-se ao fato dos mesmos participarem ativamente da elaboração dos planejamentos estratégicos de negócios e de TI, além do acompanhamento dos resultados práticos, o que Ihes dá uma visão geral sobre os objetivos estratégicos propostos e o atingimento dos mesmos pela organização.

\subsection{Instrumento(s) de pesquisa}

O instrumento de pesquisa a ser empregado neste estudo será a aplicação de um questionário, baseado nas variáveis relacionadas no modelo proposto por Rezende, de forma levantar o máximo possível de informações que viabilizem identificar o nível de alinhamento estratégico existente na empresa. No total são 25 perguntas fechadas divididas em cinco grupos que correspondem aos construtos do 
modelo proposto por Rezende. Há ainda um conjunto de duas perguntas abertas que ajudarão a complementar as opiniões dos respondentes.

As questões têm como base a revisão da literatura, obedecendo a um critério em escala de cinco possibilidades que representam a opinião sobre uma afirmação. A escala das perguntas foi baseada na técnica de Likert, também conhecida como de matriz, que tem o princípio de funcionamento de uma balança tipo gangorra e a opinião deve ser respondida como um peso que a equilibra (indiferente) ou desequilibra para algum dos lados (discordando ou concordando) (MARCONI; LAKATOS, 1996; GIL, 1999).

No questionário elaborado, as respostas são identificadas pelas letras de "a" a "e", onde "a" indica o maior grau de concordância com a questão que está sendo formulada e "e" representa o menor grau de concordância.

É importante ressaltar que as respostas devem considerar sempre a situação atual da organização, procurando evitar a opinião de condições passadas, expectativas futuras ou anseios pessoais. Ao final dos questionários haverá um espaço para comentários adicionais ou outras observações.

A elaboração do questionário, segundo Rea e Parker (2002), envolve a coleta de dados preliminares a respeito do tema e da população alvo da pesquisa, uma discussão em grupo sobre as questões e informações com os envolvidos ou interessados na pesquisa, a elaboração do rascunho do questionário, o pré-teste, a revisão do instrumento, o segundo pré-teste, se necessário, e o delineamento do questionário final.

O questionário será elaborado de modo a mensurar os fatores que promovem o alinhamento na empresa, permitindo investigar, dentro dos recursos sustentadores do modelo, o quanto as variáveis estão influenciando na integração entre os seus planejamentos. Atender isso será vital para a pesquisa.

\subsection{Procedimentos de coleta e de análise de dados}

Para a coleta de dados serão utilizadas as respostas obtidas mediante 0 questionário elaborado para os fins da pesquisa, como fonte primária. Os questionários serão enviados via e-mail após a concordância prévia de cada 
respondente. Serão obtidos dados de fontes secundárias, a serem extraídos através de análise e leitura de documentação da organização que esteja relacionada aos planos de negócio e de $\mathrm{TI}$, tais como atas de reunião, relatórios gerenciais, controle de projetos, informações de gestão, apresentações dos planejamentos estratégicos, etc.

Quanto à análise de dados, Kerlinger (1980, p.353) define esse processo como "a categorização, ordenação, manipulação e sumarização de dados". Tem por objetivo reduzir grandes quantidades de dados brutos a uma forma interpretável e mensurável. Por isso, nesta pesquisa, para a análise de dados será observada a correlação entre as variáveis pesquisadas, as respostas dos entrevistados e os documentos da fonte secundária de dados. Todos os dados coletados serão classificados segundo as variáveis delineadas no modelo, de forma a facilitar a análise interpretativa e a organizar os resultados obtidos, apresentando-os numa disposição que torne mais fácil a sua visualização. Será utilizada a técnica de análise de frequência para detectar as práticas mais promovidas e o grau de maturidade quanto à promoção do alinhamento estratégico, indo do processo ad hoc ao processo otimizado (MALHOTRA, 2002; HAIR et al., 1998).

A aplicação dos questionários deu-se entre os dias 21 de fevereiro e quatro de março de 2011 e contou com a participação de seis gerentes e seis analistas da área de TI do Sicoob Confederação. A escolha dos respondentes foi embasada principalmente pelo engajamento e nível de participação dos mesmos nos processos de desenvolvimento dos PEE e PETI da organização. 


\section{RESULTADOS E DISCUSSÃO}

Após a fase de coleta, os dados foram tabulados de forma a resumir os resultados obtidos pelos questionários, permitindo uma melhor visualização e análise dos recursos sustentadores do alinhamento do PETI ao PEE.

\subsection{Análise quantitativa}

A análise quantitativa diz respeito ao questionário fechado e retrata as frequências das respostas e os respectivos percentuais obtidos junto aos entrevistados.

As respostas referentes à Parte I - Tecnologia da Informação (TI) estão representadas:

Pergunta 1. Os computadores, seus dispositivos e periféricos utilizados

$\begin{array}{cc}\text { Respondentes } & \% \\ 4 & 26,6 \\ 8 & 53,3 \\ 2 & 13,3 \\ 1 & 6 \\ 0 & 0\end{array}$

\footnotetext{
a. Estão totalmente adequados à estratégia da organização

b. Estão parcialmente adequados à estratégia da organização

c. São indiferentes quanto a adequação à estratégia da organização

d. Estão inadequados à estratégia da organização

e. Estão totalmente inadequados à estratégia da organização
}

Os hardwares utilizados pela organização estão em média $53,3 \%$ "parcialmente adequados" à sua estratégia. Para $26 \%$ dos respondentes eles estão "totalmente adequados à estratégia da organização". Outros 13,3\% consideram que os hardwares estão "inadequados" à estratégia da organização.

Pergunta 2. Os sistemas operacionais, os utilitários e os aplicativos office utilizados

Respondentes \%

a. Estão totalmente adequados à estratégia da organização

b. Estão parcialmente adequados à estratégia da organização 960

c. São indiferentes quanto a adequação à estratégia da organização

d. Estão inadequados à estratégia da organização

e. Estão totalmente inadequados à estratégia da organização 
Os sistemas operacionais, os utilitários e os aplicativos office utilizados pela organização estão em média 60\% "parcialmente adequados" à estratégia da organização. Para $20 \%$ dos respondentes eles estão "totalmente adequados à estratégia da organização", enquanto que 13,3\% responderam que essa questão é "indiferente" à estratégia da organização.

Pergunta 3. Os sistemas de telecomunicações, as redes e seus recursos de teleprocessamento utilizados

a. Estão totalmente adequados à estratégia da organização

b. Estão parcialmente adequados à estratégia da organização

Respondentes \%

c. São indiferentes quanto a adequação à estratégia da organização

d. Estão inadequados à estratégia da organização

e. Estão totalmente inadequados à estratégia da organização

2

Os sistemas de telecomunicações, as redes e seus recursos de teleprocessamento utilizados estão em média 40\% "parcialmente adequados" à estratégia da organização e em média 26,6\% consideraram "inadequados" à estratégia da organização. Outros $20 \%$ responderam essa questão como "indiferente" para a estratégia da organização.

Pergunta 4. As tecnologias para administração e gestão de dados e de informações

$\begin{array}{cc}\text { Respondentes } & \% \\ 2 & 13,3 \\ 7 & 46,6 \\ 4 & 26,6 \\ 2 & 13,3 \\ 0 & 0\end{array}$

a. Estão totalmente adequados à estratégia da organização

b. Estão parcialmente adequados à estratégia da organização

c. São indiferentes quanto a adequação à estratégia da organização

d. Estão inadequados à estratégia da organização

e. Estão totalmente inadequados à estratégia da organização

As tecnologias para administração e gestão de dados e de informações estão em média 46,6\% "parcialmente" adequados à estratégia da organização. Para 26,6\% dos entrevistados essa questão é "indiferente" para a estratégia da organização. Para dois respondentes esses recursos estão "inadequados" e para outros dois estão "totalmente adequados" à estratégia da organização. 
Pergunta 5. A Tl e seus recursos de hardware, software, sistemas de telecomunicações e tecnologias para administração e gestão de dados de informações

a. Foram totalmente planejados com criteriosa Análise de Custos,

Respondentes \% Benefícios e Viabilidades

b. Foram parcialmente planejados com Análise de Custos, Benefícios e Viabilidades

9

3

2

Benefícios e Viabilidades

d. Não foram planejados para atender a criteriosa Análise de Custos,

Benefícios e Viabilidades

e. Estão sem qualquer planejamento quanto a Análise de Custos, Benefícios e Viabilidades $\%$

A $\mathrm{TI}$ e seus recursos de hardware, software, sistemas de telecomunicações e tecnologias para administração e gestão de dados e de informações são em média $56 \%$ "totalmente planejadas" com criteriosa Análise de Custos, Benefícios e Viabilidades. Para $20 \%$ dos entrevistados a $\mathrm{Tl}$ e seus recursos foram "parcialmente planejados". Para 13,3\% esses recursos são "indiferentes" quanto a planejamento com Análise de Custos, Benefícios e Viabilidades e para 6,6\% "não foram planejados" para atender a criteriosa Análise de Custos, Benefícios e Viabilidades.

As respostas referentes à Parte $\|$ - Sistemas de Informação e do Conhecimento (SI) estão representadas:

Pergunta 1. Os SI Operacionais que processam as operações e transações rotineiras quotidianas com seus respectivos procedimentos no seu detalhe
a. Estão totalmente adequados à estratégia da organização
b. Estão parcialmente adequados à estratégia da organização
c. São indiferentes Quanto a adequação à estratégia da organização
d. Estão inadequados à estratégia da organização
e. Estão totalmente inadequados à estratégia da organização ou inexistem

$\begin{array}{cc}\text { Respondentes } & \% \\ 5 & 33,3 \\ 6 & 40 \\ 2 & 13,3 \\ 2 & 13,3 \\ 0 & 0\end{array}$

Os SI Operacionais que processam as operações e transações rotineiras quotidianas com seus respectivos procedimentos no seu detalhe estão em média $40 \%$ "parcialmente" adequados à estratégia da organização. Para $33,3 \%$ os $\mathrm{SI}$ Operacionais estão "totalmente" adequados enquanto que 13,3\% consideram-nos "inadequados" à estratégia da organização. Para outros 13,3\% essa questão é "indiferente" para a adequação à estratégia da organização. 
Pergunta 2. Os SI Gerenciais que processam os grupos de dados das operações e das transações operacionais empresariais
a. Estão totalmente adequados à estratégia da organização
b. Estão parcialmente adequados à estratégia da organização
c. São indiferentes quanto a adequação à estratégia da organização
d. Estão inadequados à estratégia da organização
e. Estão totalmente inadequados à estratégia da organização ou inexistem

$\begin{array}{cc}\text { Respondentes } & \% \\ 6 & 40 \\ 3 & 20 \\ 1 & 6,6 \\ 5 & 33,3 \\ 0 & 0\end{array}$

Os SI Gerenciais que processam os grupos de dados das operações e das transações operacionais empresariais estão em média $40 \%$ "totalmente" adequados à estratégia da organização. Estão em média 33,3\% "inadequados" à estratégia da organização. Para $20 \%$ dos respondentes estão "parcialmente" enquanto que para $6,6 \%$ estão indiferentes quanto à adequação à estratégia da organização.

Pergunta 3. Os SI Estratégicos que processam os grupos de dados das operações e das transações gerenciais

a. Estão totalmente adequados à estratégia da organização

b. Estão parcialmente adequados à estratégia da organização

Respondentes \%

c. São indiferentes quanto a adequação à estratégia da organização

9

d. Estão inadequados à estratégia da organização

2

60

e. Estão totalmente inadequados à estratégia da organização ou inexistem

Os SI Estratégicos que processam os grupos de dados das operações e das transações gerenciais estão em média $60 \%$ "parcialmente" adequados à estratégia da organização. Estão em média para os respondentes 20\% "inadequados" à estratégia da organização. Para $13,3 \%$ essa questão é indiferente para a estratégia da organização enquanto que para $6,6 \%$ estes $S /$ estão "totalmente" inadequados à estratégia da organização.

Pergunta 4. Os SI do Conhecimento

a. Auxiliam totalmente a tomada de decisão de todos na organização

b. Auxiliam parcialmente a tomada de decisão de todos na organização

$\begin{array}{cc}\text { Respondentes } & \% \\ 0 & 0 \\ 4 & 26,6 \\ 6 & 40 \\ 3 & 20 \\ 2 & 13,3\end{array}$

c. São indiferentes quanto a auxiliar a tomada de decisão de todos na organização

d. Não auxiliam a tomada de decisão de todos na organização

e. Inexistem

2

Os SI do Conhecimento foram considerados por $40 \%$ em média "indiferentes" quanto a auxiliar a tomada de decisão de todos na organização. Em média $26,6 \%$ responderam que esses sistemas auxiliam "parcialmente" a tomada de decisão de todos na organização. Para $20 \%$ dos entrevistados esses sistemas não auxiliam a 
tomada de decisão de todos na organização. Já 13,3\% responderam que esses sistemas inexistem.

Pergunta 5. Todos os SI da organização

a. Possuem completa tecnologia de administração de base de dados

Respondentes \% para eliminar informações redundantes na organização

b. Possuem parcial tecnologia de administração de base de dados, permitindo algumas informações redundantes na organização

c. São indiferentes quanto a redundância de dados

1

6

5

evitar informações redundantes na organização, permitindo a existência de informações redundantes

e. Possuem informações redundantes, independente da existência de tecnologias de administração de base de dados
2

6,6

40

33,3

13,3

$1 \quad 6,6$

Todos os SI da organização em média 40\% possuem "parcial" tecnologia de administração de base de dados, permitindo algumas informações redundantes na organização. Em média 33,3\% responderam que esses sistemas são "indiferentes" quanto a redundância de dados. Para $6,6 \%$ dos entrevistados esses sistemas possuem "completa" tecnologia de administração de base de dados para eliminar informações redundantes na organização. Para outros $6,6 \%$ esses sistemas possuem informações redundantes, independente da existência de tecnologias de administração de base de dados.

As respostas referentes à Parte III - Pessoas ou Recursos Humanos $(\mathrm{RH})$ estão representadas:

Pergunta 1. Os valores humanos, éticos e morais das pessoas da organização.

$\begin{array}{cc}\text { Respondentes } & \% \\ 3 & 20 \\ 8 & 53,3 \\ 2 & 13,3 \\ 2 & 13,3 \\ 0 & 0\end{array}$
a. São totalmente expressos nas atividades coletivas e participativas da
organização
b. São parcialmente expressos nas atividades coletivas e participativas
da organização
c. São indiferentes para a organização
d. Não são expressos nas atividades coletivas e participativas da organização
e. Inexistem esses valores ou inexistem as atividades coletivas e
participativas na organização

Os valores humanos, éticos e morais das pessoas da organização são em média 53,3 são "parcialmente" expressos nas atividades coletivas e participativas da organização. Para $20 \%$ dos entrevistados esses valores são totalmente expressos nas atividades coletivas e participativas da organização. Para em média 13,3\% essa questão é indiferente para a organização. Já outros 13,3\% responderam que esses valores "não são" expressos nas atividades coletivas e participativas da organização. 
Pergunta 2. Os profissionais da equipe da TI da organização (técnicos da TI)

a. São constantemente capacitados nas suas atividades

Respondentes \%

b. São frequentemente capacitados nas suas atividades

$2 \quad 13,3$

c. É indiferente para a organização

46,6

d. Não são capacitados nas suas atividades

320

e. Inexiste essa exigência de capacitação dos profissionais da TI

20

$\begin{array}{lll}3 & 20 \\ 0 & 0\end{array}$

Os profissionais da equipe da TI da organização (técnicos da TI) são para em média $46,6 \%$ dos entrevistados "frequentemente" capacitados nas suas atividades. Para $20 \%$ "não são" capacitados nas suas atividades enquanto que para outros 13,3\% eles são "constantemente" capacitados nas suas atividades. $20 \%$ dos respondentes consideraram essa questão "indiferente" para a organização.

Pergunta 3. As atividades pertinentes ao PEE e ao PETI

$\begin{array}{cc}\text { Respondentes } & \% \\ 3 & 20 \\ 8 & 53,3 \\ 2 & 13,3 \\ 1 & 6,6 \\ 1 & 6,6\end{array}$

a. São totalmente elaboradas por equipe multidisciplinar que preserva os talentos internos da organização 20

b. São parcialmente elaboradas por equipe multidisciplinar que preserva os talentos internos

c. São indiferentes para a organização

d. Não são elaboradas por equipe multidisciplinar que preserva os talentos internos

e. Inexiste essa necessidade de equipe multidisciplinar as atividades de planejamento

As atividades pertinentes ao PEE e ao PETI são para em média 53,3\% dos entrevistados "parcialmente" elaboradas por equipe multidisciplinar que preserva os talentos internos da organização. São em média para 20\% dos respondentes "totalmente" elaboradas por equipe multidisciplinar que preserva os talentos internos da organização. Para 13,3 \% essa questão é "indiferente" para a organização enquanto que para $6,6 \%$ essas atividades "não são" elaboradas por equipe multidisciplinar que preserva os talentos internos. Para outros $6,6 \%$ dos respondentes "inexiste" essa necessidade de equipe multidisciplinar as atividades de planejamento. 
Pergunta 4. A troca de experiências e de aprendizado entre os profissionais envolvidos nas atividades de planejamento da organização

$\begin{array}{cc}\text { Respondentes } & \% \\ 1 & 6,6 \\ 2 & 13,3 \\ 4 & 26,6 \\ 6 & 40 \\ 2 & 13,3\end{array}$

40

13,3 desses profissionais

A troca de experiências e de aprendizado entre os profissionais envolvidos nas atividades de planejamento da organização para em média $40 \%$ dos entrevistados "não é promovida" pela organização. Para 26,6\% dos respondentes essa troca de experiências é "indiferente" para a organização. Para 13,3\% ela é "parcialmente" promovida pela organização enquanto que para outros 13,3\% "inexiste" essa necessidade troca de experiências e de aprendizado desses profissionais.

Pergunta 5. O clima no ambiente de trabalho da organização

a. Facilita completamente as atividades de planejamento da organização

Respondentes \%

b. Facilita parcialmente as atividades de planejamento da organização

$5 \quad 33,3$

c. É indiferente para a organização

d. Não facilita as atividades de planejamento da organização

$7 \quad 46,6$

e. Inexiste essa necessidade de clima de trabalho na organização

O clima no ambiente de trabalho da organização "facilita parcialmente" as atividades de planejamento da organização para em média $46,6 \%$ dos respondentes. Para $33,3 \%$ em média o clima "facilita completamente" as atividades de planejamento da organização. Em média 13,3\% consideram que o clima "não facilita" as atividades de planejamento da organização. Para $6,6 \%$ essa questão é "indiferente" para a organização. 
As respostas referentes à Parte IV - Contexto Organizacional (CO) estão representadas:

Pergunta 1. A missão, os objetivos e as estratégias da organização

a. Estão totalmente formuladas e claramente comunicadas para os

Respondentes

8

$\%$

envolvidos no PEE e no PETI

b. Estão parcialmente formuladas e comunicadas para os envolvidos no

PEE e no PETI

c. É indiferente para a organização

d. Não estão formuladas e comunicadas para os envolvidos no PEE e no PETI

e. Inexiste essa necessidade de formulação
426,6

$2 \quad 13,3$

16,6

0

A missão, os objetivos e as estratégias da organização estão para em média 53,3\% dos respondentes estão "totalmente" formuladas e claramente comunicadas para os envolvidos no PEE e no PETI. Para em média 26,6\% dos entrevistados estão "parcialmente". Para 13,3\% essa questão é "indiferente" para a organização e para $6,6 \%$ "não estão" formuladas e comunicadas para os envolvidos no PEE e no PETI.

Pergunta 2. Os planos de ação relacionados ao PEE e ao PETI

a. Estão totalmente definidos, descritos e comunicados para os envolvidos Respondentes \% nessas atividades

b. Estão parcialmente definidos, descritos e comunicados para os envolvidos nessas atividades

$8 \quad 53,3$

c. É indiferente para a organização

3

d. Não estão definidos, descritos e comunicados para os envolvidos nessas atividades

e. Inexiste essa necessidade ou inexistem os planos de ação do PEE e do PETI

0

0

Os planos de ação relacionados ao PEE e ao PETI estão para em média $53,3 \%$ dos entrevistados "parcialmente" definidos, descritos e comunicados para os envolvidos nessas atividades. $20 \%$ consideram que essa questão é "indiferente" para a organização. Para $13,3 \%$ os planos estão "totalmente" definidos, descritos e comunicados para os envolvidos nessas atividades. Outros $13,3 \%$ consideram que eles "não estão" definidos. 
Pergunta 3. A cultura, a filosofia e as políticas da organização

a. Estão totalmente transparentes, positivas e disseminadas

b. Estão parcialmente transparentes, positivas e disseminadas

Respondentes \%

c. É indiferente para a organização

$6 \quad 40$

d. Não estão transparentes, positivas e disseminadas

e. Inexiste essa necessidade de transparência e disseminação

A cultura, a filosofia e as políticas da organização estão para em média $40 \%$ dos entrevistados "parcialmente" transparentes, positivas e disseminadas. Para 33,3\% dos respondentes essa questão é "indiferente" para a organização. Em média 20\% consideram que estão "totalmente" transparentes, positivas e disseminadas enquanto que $6,6 \%$ responderam que "não estão" transparentes, positivas e disseminadas.

Pergunta 4. Os investimentos em $\mathrm{Tl}$, em SI, em recursos humanos e em infraestrutura organizacional

a. Estão totalmente previstos e precisamente quantificados no PEE

Respondentes \%

b. Estão parcialmente previstos e quantificados no PEE

c. É indiferente para a organização

d. Não estão previstos e quantificados no PEE

e. Inexiste essa necessidade de investimento

7

6

$2 \quad 13,3$

0

0
46,6

0

Os investimentos em $\mathrm{Tl}$, em SI, em recursos humanos e em infraestrutura organizacional estão em média para 46,6\% dos entrevistados "totalmente" previstos e precisamente quantificados no PEE. Para $40 \%$ em média estão "parcialmente" previstos e quantificados no PEE. Para 13,3\% dos respondentes essa questão é "indiferente" para a organização.

Pergunta 5. Os investimentos elaborados pela organização em Tl e seus recursos para o PETI

a. Alcançam totalmente os resultados predefinidos

b. Alcançam parcialmente os resultados predefinidos

c. É indiferente para a organização

d. Não alcançam os resultados predefinidos

e. Inexiste essa necessidade alcançar os resultados predefinidos pela organização

Respondentes \%

$1 \quad 6,6$

$10 \quad 66,6$

320

16,6

$0 \quad 0$ 
Os investimentos elaborados pela organização em $\mathrm{Tl}$ e seus recursos para o PETI alcançam "parcialmente" os resultados predefinidos para em média 66,6\% dos entrevistados. Em média $20 \%$ consideram essa questão "indiferente" para a organização. Para $6,6 \%$ os investimentos alcançam "totalmente" os resultados predefinidos enquanto que para outros $6,6 \%$ "não alcançam" esses resultados.

As respostas referentes à Parte V - Alinhamento Estratégico (AE) estão representadas:

Pergunta 1. As estratégias das funções empresariais de toda a organização

Respondentes \%

a. Estão totalmente identificadas e integradas na organização

$1 \quad 6,6$

b. Estão parcialmente identificadas e integradas na organização

$11 \quad 73,3$

c. É indiferente para a organização

$2 \quad 13,3$

d. Não estão identificadas e integradas na organização

16,6

e. Inexiste essa necessidade identificação e integração das funções empresariais na organização

0

0

As estratégias das funções empresariais de toda a organização estão para em média 73,3\% dos entrevistados "parcialmente" identificadas e integradas na organização. Para 13,3\% essa questão é indiferente para a organização. Em média 6,6\% responderam que as estratégias estão "totalmente" identificadas e integradas na organização enquanto que para outros $6,6 \%$ elas não estão identificadas e integradas na organização.

Pergunta 2. As tecnologias disponíveis na organização (de Tle organizacional)

Respondentes \%

a. Estão totalmente adequadas à estratégia da organização

b. Estão parcialmente adequadas à estratégia da organização

2

13,3

c. São indiferentes quanto a adequação à estratégia da organização

d. Estão inadequadas à estratégia da organização

e. Estão totalmente inadequadas à estratégia da organização
$7 \quad 46,6$

$2 \quad 13,3$

320

$1 \quad 6,6$

As tecnologias disponíveis na organização (de Tl e organizacional) estão em média para 46,6\% dos entrevistados "parcialmente" adequadas à estratégia da organização. Para $20 \%$ as tecnologias "estão inadequadas" à estratégia da 
organização. Para 13,3\% em média elas estão "totalmente" adequadas à estratégia da organização. Outros 13,3\% opinaram que essas tecnologias são "indiferentes" quanto à adequação à estratégia da organização. Para 6,6\% dos respondentes elas estão totalmente inadequadas à estratégia da organização.

Pergunta 3. A gestão do PETI

a. Está totalmente adequada e alinhada à estratégia da organização

b. Está parcialmente adequada e alinhada à estratégia da organização

Respondentes \%

c. É indiferente quanto a adequação e alinhamento à estratégia da organização

d. Está inadequada e desalinhada à estratégia da organização

e. Está totalmente inadequada e desalinhada à estratégia da organização

$3-20$

$8 \quad 53,3$

320

$1 \quad 6,6$

$0 \quad 0$

A gestão do PETI está para em média 53,3\% dos respondentes "parcialmente" adequada e alinhada à estratégia da organização. Para $20 \%$ a gestão do PETI está "totalmente" adequada e alinhada à estratégia da organização, enquanto que para outros $20 \%$ ela é "indiferente". Em média 6,6\% dos respondentes consideram essa gestão "inadequada" e desalinhada à estratégia da organização.

Pergunta 4. A gestão do PEE e do PETI

a. É uma atividade de total parceria e cogestão integrada

b. É uma atividade de parcial parceria e cogestão integrada

c. É indiferente para a organização

d. Não é uma atividade de parceria e cogestão integrada

e. Inexiste essa necessidade de estabelecer parceria e cogestão integrada desses planejamentos

$\begin{array}{cc}\text { Respondentes } & \% \\ 3 & 20 \\ 7 & 46,6 \\ 2 & 13,3 \\ 3 & 20 \\ 0 & 0\end{array}$

A gestão do PEE e do PETI é para $46,6 \%$ dos entrevistados em média uma atividade de "parcial" parceria e cogestão integrada. Para 20\% em média é uma atividade de "total" parceria e cogestão integrada. Para outros $20 \%$ não é uma atividade de parceria e cogestão integrada. Outros 13,3\% consideram essa questão indiferente para a organização. 
Pergunta 5. Os indicadores de mensuração ou critérios que permitem as avaliações dos resultados do PEE e do PETI

Respondentes \%

a. Estão totalmente definidos, descritos e comunicados aos envolvidos nessas atividades

b. Estão parcialmente definidos, descritos e comunicados aos envolvidos nessas atividades

c. É indiferente para a organização

d. Não estão definidos, descritos e comunicados para os envolvidos

nessas atividades

e. Inexiste essa necessidade definição, descrição e comunicação destes critérios

0

8

2

4

1
0

53,3

13,3

26,6

6,6

Os indicadores de mensuração ou critérios que permitem as avaliações dos resultados do PEE e do PETI para em média 53,3\% dos entrevistados estão "parcialmente" definidos, descritos e comunicados aos envolvidos nessas atividades. "Não estão" definidos, descritos e comunicados para os envolvidos nessas atividades para 26,6\%. Para $13,3 \%$ dos respondentes essa questão é "indiferente" para a organização. Outros 6,6\% consideram que "inexiste" essa necessidade definição, descrição e comunicação destes critérios.

\subsection{Análise quanti-qualitativa}

Nessa parte da análise foram consideradas somente as respostas "a", ou seja, quando a pergunta foi respondida de forma totalmente satisfatória pelos respondentes. O objetivo é perceber detalhes, descobrir enfoques e estabelecer diversas interpretações e inferências, no que diz respeito ao alinhamento do PETI ao PEE da empresa em estudo (REZENDE,2002). Foram descartadas as outras respostas sobre os construtos do modelo, mas consideradas as observações, exemplos e complementações dos respondentes, oriundas das entrevistas ou dos questionários.

De acordo com a escala de Likert as respostas do tipo "a" são as que indicam o maior grau de concordância com a questão que está sendo formulada. Nesse caso uma maior quantidade de respostas do tipo "a" representa uma maior contribuição do construto em análise para a sustentação do alinhamento estratégico. 
Para que análise dos dados da pesquisa fosse viabilizada, foi necessário elaborar critérios para interpretar os seus resultados por meio de um protocolo de análise (Rezende, 2002 apud GIL, 1999; AUDY 2001). Nesse protocolo se estabeleceu uma relação entre os construtos e respectivas variáveis do modelo proposto através de níveis de mensuração descritos na Tabela 7.

\section{Tabela 7}

Níveis de Mensuração do Protocolo de Análise

\begin{tabular}{l|l}
\hline Conceito Conduta & \\
\hline Alto & Para acima de $70 \%$ do percentual médio das respostas \\
\hline Bom & Entre $50 \%$ e $70 \%$ do percentual médio das respostas \\
\hline baixo & Para abaixo de $50 \%$ do percentual médio das respostas \\
\hline
\end{tabular}

Com o protocolo de análise estabelecido, a identificação dos recursos sustentadores do alinhamento do PETI ao PEE foi facilitada quando da verificação do modelo proposto junto participantes da pesquisa.

A Tabela 8 expressa o resumo analisado indicando o percentual de respondentes para as respostas do tipo "a".

Tabela 8

Resumo das Respostas Tipo "a" do Questionário Aplicado

\begin{tabular}{l|c}
\hline \multicolumn{1}{c|}{ PERGUNTAS } & $\%$ \\
\hline Parte I - Tecnologia da Informação (TI) & \\
\hline $\begin{array}{l}\text { Pergunta 1. Os computadores, seus dispositivos e periféricos utilizados } \\
\text { a. Estão totalmente adequados à estratégia da organização }\end{array}$ & 26,6 \\
\hline $\begin{array}{l}\text { Pergunta 2. Os sistemas } \\
\text { a. Estão totalmente adequados à estratégia da organização }\end{array}$ & 20 \\
\hline $\begin{array}{l}\text { Pergunta 3. Os sistemas de telecomunicações, as redes e seus recursos de } \\
\text { teleprocessamento utilizados } \\
\text { a. Estão totalmente adequados à estratégia da organização }\end{array}$ & 13,3 \\
\hline $\begin{array}{l}\text { Pergunta 4. As tecnologias para administração e gestão de dados e de informações } \\
\text { a. Estão totalmente adequados à estratégia da organização }\end{array}$ & 13,3 \\
\hline $\begin{array}{l}\text { Pergunta 5. A TI e seus recursos de hardware, software, sistemas de telecomunicações e } \\
\text { tecnologias para administração e gestão de dados e de informações } \\
\text { a. Foram totalmente planejados com criteriosa Análise de Custos, Benefícios e Viabilidades }\end{array}$ & \multirow{2}{*}{60} \\
\hline Parte II - Sistemas de Informação e do Conhecimento (SI) & \\
\hline
\end{tabular}


Pergunta 1. Os SI Operacionais que processam as operações e transações rotineiras quotidianas com seus respectivos procedimentos no seu detalhe

a. Estão totalmente adequados à estratégia da organização

Pergunta 2. Os SI Gerenciais que processam os grupos de dados das operações e das transações operacionais empresariais

a. Estão totalmente adequados à estratégia da organização

Pergunta 3. Os SI Estratégicos que processam os grupos de dados das operações e das transações gerenciais

a. Estão totalmente adequados à estratégia da organização

Pergunta 4. Os SI do Conhecimento

c. Estão totalmente adequados à estratégia da organização

Pergunta 5. Todos os SI da organização

a. Foram totalmente planejados com criteriosa Análise de Custos, Benefícios e Viabilidades.

\section{Parte III - Pessoas ou Recursos Humanos (RH)}

Pergunta 1. Os valores humanos, éticos e morais das pessoas da organização.

a. São totalmente expressos nas atividades coletivas e participativas da organização

Pergunta 2. Os profissionais da equipe da TI da organização (técnicos da TI)

b. São constantemente capacitados nas suas atividades

Pergunta 3. As atividades pertinentes ao PEE e ao PETI

a. São totalmente elaboradas por equipe multidisciplinar que preserva os talentos internos

Pergunta 4. A troca de experiências e de aprendizado entre os profissionais envolvidos nas

atividades de planejamento da organização

a. É totalmente promovida pela organização

Pergunta 5. O clima no ambiente de trabalho da organização

a. Facilita completamente as atividades de planejamento da organização

\section{Parte IV - Contexto Organizacional (CO)}

Pergunta 1. A missão, os objetivos e as estratégias da organização

a. Estão totalmente formuladas e claramente comunicadas para os envolvidos no PEE e no PETI

Pergunta 2. Os planos de ação relacionados ao PEE e ao PETI

a. Estão totalmente definidos, descritos e comunicados para os envolvidos nessas atividades Pergunta 3. A cultura, a filosofia e as políticas da organização

a. Estão totalmente transparentes, positivas e disseminadas

Pergunta 4. Os investimentos em $\mathrm{Tl}$, em Sl, em recursos humanos e em infraestrutura organizacional

a. Estão totalmente previstos e precisamente quantificados no PEE

Pergunta 5. Os investimentos elaborados pela organização em $\mathrm{Tl}$ e seus recursos para $O$ PETI

a. Alcançam totalmente os resultados predefinidos

\section{Parte V - Alinhamento Estratégico (AE)}

Pergunta 1. As estratégias das funções empresariais de toda a organização

a. Estão totalmente identificadas e integradas na organização

Pergunta 2. As tecnologias disponíveis na organização (de Tl e organizacional)

a. Estão totalmente adequadas à estratégia da organização 


\begin{tabular}{l|c}
\hline Pergunta 3. A gestão do PETI & 20 \\
$\begin{array}{l}\text { a. Está totalmente e adequada e alinhada à estratégia da organização } \\
\text { Pergunta 4. A gestão do PEE e do PETI }\end{array}$ & 20 \\
$\begin{array}{l}\text { a. É uma atividade de total parceria e cogestão integrada } \\
\text { Pergunta 5. Os indicadores de mensuração ou critérios que permitem as avaliações dos } \\
\text { resultados do PEE e do PETI }\end{array}$ & 0 \\
a. Estão totalmente definidos, descritos e comunicados aos envolvidos nessas atividades & \\
\hline
\end{tabular}

Quanto à primeira parte do questionário, relativas ao construto $\mathrm{TI}$ (Tecnologia da Informação), pôde-se perceber que os computadores e seus dispositivos têm um baixo índice-médio de adequação (26,6\%). Os níveis de desenvolvimento de novos sistemas informatizados têm sido altos e o próprio crescimento da rede de cooperativas que indica a constante necessidade da organização quanto ao aumento do seu parque de equipamentos.

Os sistemas também têm um baixo índice-médio de adequação (20\%). A baixa adequação está de certa forma associada à constante necessidade de aumento do parque computacional.

Os sistemas de telecomunicações e seus recursos ficaram com baixo índice-médio de adequação (13,3\%). A rede de atendimento do sistema Sicoob compreende 1700 pontos que estão interligados ao sítio de processamento central de Brasília. Devido à capilaridade da rede e a sua abrangência geográfica, os recursos de telecomunicações que provêm essa conectividade são fornecidos por várias empresas do setor. Isso implica em contratos com níveis de serviços diferenciados, gerando problemas de disponibilidade para as cooperativas que estão localizadas em regiões cuja oferta de serviços de telecomunicações ainda é restrita.

As tecnologias para administração e gestão de dados também obtiveram um baixo índice-médio de adequação (13,3\%). O Sicoob encontra-se numa fase de transição de arquitetura de sistemas, envolvendo novas plataformas de desenvolvimento, linguagens de programação, modelos de dados, sistemas gerenciadores de bancos de dados, servidores de porte empresarial e mainframes e soluções de armazenamento de grande capacidade, o que explica a opinião dos entrevistados quanto à atual adequação desses sistemas.

A $\mathrm{TI}$ e seus recursos apresentaram um bom índice-médio de planejamento (60\%). Isso reflete em parte o resultado prático do PETI do Sicoob que tem como objetivo adequar todos os seus recursos de hardware e software, sistemas de 
telecomunicações e tecnologias para gestão de dados às necessidades demandadas pelas áreas de negócios da empresa.

Pôde-se observar que os SI operacionais têm um baixo índice-médio de adequação (33,3\%). Esses sistemas estão frequentemente relacionados com os sistemas que ainda não migraram para a nova arquitetura e que não estão sendo objeto de grandes esforços quanto à sua evolução pela área de desenvolvimento da organização.

Os $\mathrm{Si}$ gerenciais obtiveram um baixo índice-médio de adequação $(40 \%)$. Sob a ótica do pessoal de $\mathrm{TI}$, esses sistemas ainda precisam ser aprimorados de forma a acompanhar as necessidades das áreas de negócios demandantes.

Os SI estratégicos e os do conhecimento não foram considerados por nenhum dos respondentes como estando totalmente adequados à estratégia da organização. Esse baixo nível-médio é efeito das dificuldades dos sistemas operacionais que deixam a desejar e geram informações inoportunas. Se as informações operacionais ainda não foram resolvidas na sua totalidade, as informações estratégicas e do conhecimento também não poderiam ser oportunas.

Os SI da organização, como um todo, obtiveram um baixo índice-médio quanto ao seu planejamento $(6,6 \%)$. Observa-se que o planejamento total deve ser melhor trabalhado para efeito de atingimento do alinhamento baseado no recurso sustentador SI.

Pôde-se observar que os valores humanos, éticos e morais das pessoas da organização têm um baixo índice-médio de adequação (20\%) relacionado às atividades coletivas e participativas da organização. Essa é uma atividade que vem sendo dada muita atenção pela área organizacional do Sicoob e que suscitou na criação de um PDH - Programa de Desenvolvimento Humano em 2010. Esse programa está ancorado em treinamento com vários módulos, sempre com presença de funcionários das áreas organizacional e de $\mathrm{TI}$, com foco no desenvolvimento de habilidades relacionadas às atividades coletivas e participativas da organização.

Os profissionais da equipe de TI obtiveram um baixo nível-médio de adequação (13,3\%) quanto à sua constante capacitação nas suas atividades. Esse também é um cenário que está mudando aos poucos na área de TI visto que toda a aquisição prevista para recursos de hardware ou software já contempla treinamento para sua implantação, operação e suporte e, em alguns casos, certificação oficial por parte do fornecedor/fabricante do produto. 
As atividades pertinentes ao PEE e ao PETI apresentaram baixo índicemédio de adequação (20\%) quanto a serem totalmente elaboradas por equipe multidisciplinar que preserva os talentos internos. Essa percepção dos profissionais da área de TI demonstra que há a necessidade de aumentar a participação de todos os segmentos da organização quando da elaboração dos planos estratégicos. Essa é uma condição que também vem sendo considerada pelo Sicoob, já que as primeiras versões do PETI era praticamente elaborada pelos gerentes da área e hoje já há uma maior participação de analistas das diversas áreas de TI. Esforço semelhante tem sido observado quanto à elaboração do PEE.

A troca de experiências e de aprendizado entre os profissionais de $\mathrm{TI}$ apresentou um baixo índice-médio de adequação $(6,6 \%)$ quanto à promoção dessas atividades pela organização. Esse é um fator que precisa ser melhor trabalhado pelo Sicoob mas que já está recebendo uma maior atenção pelos executivos, que têm incentivado internamente a promoção de workshops para uma maior troca de experiências entre os funcionários da área.

O clima no ambiente de trabalho da organização revelou um baixo índicemédio de adequação (33,3\%) quanto a facilitar totalmente as atividades de planejamento da organização. Embora esse item tenha sido pouco pontuado, dentre as variáveis desse recurso sustentador foi o que obteve melhor resultado. Estabelecer um clima totalmente ótimo é algo muito difícil de ser alcançado porque também envolve muito do comportamento dos colaboradores. No caso da TI do Sicoob deve se ressaltar que aproximadamente dois terços dos colaboradores são terceirizados e que não têm vínculo empregatício direto com a organização. Essa condição eventualmente concorre para que o clima não seja totalmente favorável, já que ocorrem em muitos casos conflitos quanto à remuneração, participação em treinamentos, viagens a serviço, dentre outros motivos.

Pôde-se observar que a missão, os objetivos e as estratégias da organização têm um bom índice-médio de adequação $(53,3)$ quanto a estarem totalmente formuladas e claramente comunicadas para os envolvidos no PETI e no PEE. Esse índice obtido já sinaliza que os movimentos de divulgação dos objetivos da corporação têm resultado numa maior disseminação dessas variáveis e estratégias do Sicoob, principalmente pelos funcionários que têm função de gestão na organização. 
Os planos de ação relacionados ao PEE e ao PETI obtiveram um baixo índice-médio de adequação (13,3\%) quanto a estarem totalmente definidos, descritos e comunicados para os envolvidos nessas atividades. Essa condição corrobora com o fato dos processos das funções organizacionais ainda não estarem devidamente documentados o que, por sua vez, reflete na definição e elaboração dos planos de ação.

A cultura, a filosofia e as políticas da organização receberam um baixo índice-médio de adequação (20\%) quanto a estarem totalmente transparentes, positivas e disseminadas. O Siccob têm se preocupado com essa questão e, recentemente, criou um grupo com estrutura matricial para definir a implantação de programas de avaliação de desempenho, pesquisa de clima e aperfeiçoamento pessoal através de bolsas de estudos.

Os investimentos em TI, em SI, em recursos humanos e em infraestrutura organizacional apresentaram um baixo índice-médio de planejamento $(46,6 \%)$ quanto a estarem totalmente previstos e precisamente quantificados no PEE. $O$ planejamento efetuado para vários desses recursos muitas vezes é baseado em séries históricas de crescimento e, nem sempre consegue prever com certeza a expansão do sistema Sicoob como um todo. Nos últimos anos o Sicoob tem apresentado fortes evoluções quanto ao número de transações efetivadas pelas cooperativas, pelo seu banco, pelas centrais e também quanto ao número de produtos que constantemente são incorporados ao seu portfolio de produtos.

Os investimentos elaborados pela organização em TI e seus recursos para o PETI tiveram um baixo índice-médio de planejamento $(6,6 \%)$ quanto a alcançarem totalmente os resultados predefinidos. Esse resultado corrobora com o anterior e se reflete em maior intensidade nos recursos previstos no PETI, já que o Siccob por ser uma instituição de cunho financeiro é muito dependente de recursos de TI.

As estratégias das funções empresariais de toda a organização receberam um baixo índice-médio de adequação (6,6\%) quanto estarem totalmente identificadas e integradas na organização. Esse resultado evidencia a falta de disseminação dessas estratégias junto ao corpo funcional do Sicoob, através de um veículo de comunicação interna mais eficiente.

As tecnologias disponíveis na organização (de $\mathrm{TI}$ e organizacional) obtiveram um baixo índice-médio de adequação (13,3\%) quanto à estratégia da organização. Essa avaliação está relacionada com a dificuldade de adequar os 
recursos de $\mathrm{Tl}$ e a infraestrutura organizacional na organização. Isso indica uma grande dificuldade de adequação de todas as tecnologias as estratégias empresariais.

A gestão do PETI recebeu um baixo nível-médio de adequação (20\%) quanto ao seu total alinhamento à estratégia da organização. Essa atividade está sendo melhorada com a implantação de revisões trimestrais do PETI dentro da organização. Esse exercício tem propiciado pontos de controle quanto à execução dos planos e, em muitos casos, tem resultado em ajustes de curso entre o planejado e o que está sendo executado.

A gestão do PEE e do PETI teve um baixo índice-médio de adequação (20\%) quanto ao seu total alinhamento á estratégia da organização. Essa questão está intimamente ligada à anterior e demonstra uma necessidade de maior utilização mecanismos de gestão compartilhada e participativa com foco no alinhamento estratégico do PETI ao PEE.

Nenhum dos respondentes considerou os indicadores de mensuração ou critérios que permitem as avaliações dos resultados do PEE e do PETI como totalmente definidos, descritos e comunicados aos envolvidos nessas atividades. Apesar de o Siccob possuir metodologia formal de PEE e PETI que contem indicadores de resultados, especialmente quanto ao retorno que os investimentos em TI podem resultar, observa-se a necessidade de formalizar os resultados desses planejamentos dentro da organização.

\subsection{Fechamento da análise}

O fechamento das análises do alinhamento do PETI ao PEE refere-se às análises das variáveis contidas no modelo de alinhamento do PETI ao PEE proposto e ainda as três perguntas abertas do questionário.

\subsubsection{Análise das respostas das variáveis}


A análise das respostas das variáveis do modelo proposto relaciona-se com os níveis mensurados nas análises quanti-qualitativa, onde foram consideradas somente as respostas do tipo "a" do questionário aplicado e indica quais construtos contribuem em maior ou menor grau para o alinhamento estratégico.

O resumo com a referida análise pode ser retratado na Tabela 9.

Tabela 9

Média das Respostas tipo "a" por Construto

\begin{tabular}{|c|c|}
\hline Parte I - Tecnologia da Informação (TI) & $\%$ \\
\hline 1 - Computadores & 26,6 \\
\hline 2 - Sistemas operacionais & 20 \\
\hline 3 - Sistemas de telecomunicações & 13,3 \\
\hline 4 - Gestão de dados e de informações & 13,3 \\
\hline $5-\mathrm{A}$ TI e seus recursos & 60 \\
\hline Média & 26,6 \\
\hline Parte II - Sistemas de Informação e do Conhecimento (SI) & $\%$ \\
\hline 1 - Os SI Operacionais & 33,3 \\
\hline 2 - Os SI Gerenciais & 40 \\
\hline 5 - Todos os SI da organização & 6,6 \\
\hline Média & 26,6 \\
\hline Parte III - Pessoas ou Recursos Humanos (RH) & $\%$ \\
\hline 1 - Os valores humanos & 20 \\
\hline 2 - Os profissionais da equipe da $\mathrm{TI}$ & 13,3 \\
\hline 3 - As atividades pertinentes ao PEE e ao PETI & 20 \\
\hline 4 - A troca de experiências & 6,6 \\
\hline 5 - O clima & 33,3 \\
\hline Média & 18,6 \\
\hline Parte IV - Contexto Organizacional (CO) & $\%$ \\
\hline 1 - A missão, os objetivos e as estratégias & 53,3 \\
\hline 2 - Os planos de ação relacionados ao PEE e ao PETI & 13,3 \\
\hline 3 - A cultura, a filosofia e as políticas da organização & 20 \\
\hline 4 - Os investimentos em TI, SI, RH e infra organizacional & 46,6 \\
\hline 5 - Os investimentos em TI para o PETI & 6,6 \\
\hline
\end{tabular}




\section{Média 27,9 \\ Média Geral 24,9}

Com relação às médias observadas o construto que mais vem ao encontro do alinhamento do PETI ao PEE é o Contexto Organizacional. Por outro lado, o construto Pessoas ou Recursos Humanos contribuiu com a média mais baixa na mensuração. Isso nos leva a acreditar que o planejamento que envolve as pessoas e suas capacitações deve ser mais trabalhado a fim de melhorar com o referido alinhamento no Sicoob.

\subsubsection{Análise do percentual do alinhamento do PETI ao PEE}

Tendo como base a primeira pergunta aberta do questionário aplicado, será feita a análise do percentual do alinhamento do PETI ao PEE.

Relativamente à pergunta "Diante de todas essas respostas, qual o percentual de alinhamento entre o PETI e o PEE em sua organização?", foram dadas as respostas constantes da Tabela 10.

Tabela 10

Percepção dos Entrevistados Quanto ao Percentual de Alinhamento

\begin{tabular}{|l|c|}
\hline \multicolumn{1}{|c|}{ Respondente } & Média \\
\hline Respondente 1 & $50 \%$ \\
\hline Respondente 2 & $70 \%$ \\
\hline Respondente 3 & $10 \%$ \\
\hline Respondente 4 & $30 \%$ \\
\hline Respondente 5 & $30 \%$ \\
\hline Respondente 6 & $70 \%$ \\
\hline Respondente 7 & $20 \%$ \\
\hline Respondente 8 & $50 \%$ \\
\hline Respondente 9 & $40 \%$ \\
\hline
\end{tabular}




\begin{tabular}{|c|c|}
\hline Respondente 10 & $60 \%$ \\
\hline Respondente 11 & $50 \%$ \\
\hline Respondente 12 & $40 \%$ \\
\hline Respondente 13 & $50 \%$ \\
\hline Respondente 14 & $30 \%$ \\
\hline Respondente 15 & $40 \%$ \\
\hline Média & $42,6 \%$ \\
\hline
\end{tabular}

O percentual de alinhamento entre o PETI e o PEE no Sicoob, sob a percepção dos gestores de $\mathrm{TI}$ e analistas de $\mathrm{TI}$ é de $42,6 \%$. Esse percentual pode ser relacionado com o percentual médio das respostas constantes da Tabela 9, referentes à análise das variáveis do modelo proposto. Observa-se uma diferença de $17,7 \%$ entre o percentual médio de alinhamento obtido na resposta aberta e o percentual médio obtido nas respostas fechadas que foi de $24,9 \%$.

Pelos percentuais alcançados nos dois tipos de aferição junto aos gestores e analistas da área de TI, abaixo de $50 \%$ na média, pode-se concluir que o Sicoob ainda encontra-se num estágio de baixo alinhamento entre o PETI e o PEE. Considerando-se que até o momento só foi realizado um PEE e três PETI, é possível identificar certa maturidade do PETI em relação ao PEE quanto à sua elaboração. Isso pode ser corroborado na metodologia que vem sendo utilizada na formulação do PETI e do PEE.

\subsubsection{Análise das respostas das questões abertas}

Essa análise refere-se à última pergunta aberta do questionário aplicado e que fornecia livre espaço para que os respondentes comentassem suas percepções quanto ao alinhamento do PETI ao PEE no Sicoob.

As respostas da pergunta "Utilize este espaço para seus comentários adicionais" forneceram percepções importantes por parte dos entrevistados que, de forma resumida, expressaram as seguintes observações: 
- Com o PETI ocorre um adequado acompanhamento e avaliação, o que não ocorre com o PEE cujas métricas de acompanhamento são desconhecidas;

- O aumento no investimento em TI é aparentemente proporcional ao crescimento da instituição;

- Periodicamente as atividades de TI são apresentadas formalmente à Diretoria Colegiada com intuito de transparecer todo o investimento feito na área de $\mathrm{Tl}$, podendo efetivamente influenciar nas decisões estratégicas da instituição;

- O esforço individual dos gerentes e das suas equipes é que viabiliza o alinhamento;

- O alinhamento entre o PETI e o PEE é muito complexa e difícil de acontecer na sua plenitude;

- A empresa necessita de mais recursos humanos para atender o PEE.

Alguns entrevistados optaram por não utilizar essa parte do questionário por entenderem que o próprio questionário fechado já era suficiente para expressar a suas opiniões. 


\section{CONCLUSÕES E RECOMENDAÇÕES}

Este capítulo apresenta os resultados alcançados pelo presente trabalho que teve como foco principal a avaliação do alinhamento entre o planejamento estratégico de negócios e o planejamento estratégico da tecnologia da informação do Sicoob Confederação. Além deste, os outros objetivos consistiam em identificar como são formulados os PEE e PETI da empresa e analisar os resultados quanto à percepção dos executivos da empresa sobre o objetivo geral do trabalho.

Foi realizada uma pesquisa de natureza descritiva, com abordagem quantiqualitativa e o método selecionado foi o de estudo de caso, utilizando como instrumento de mensuração o Modelo de Alinhamento do Planejamento Estratégico de Negócios e Planejamento Estratégico de TI de Rezende (2002).

A empresa analisada foi o Sicoob Confederação tendo como instrumento de pesquisa um questionário, como fonte primária de dados, que foi aplicado a alguns gestores e analistas da área de $\mathrm{TI}$ da empresa. Como fonte secundária de dados foram utilizados alguns documentos corporativos como o PEE e PETI do Sicoob.

A partir dos dados coletados e analisados serão apresentados os resultados alcançados, a relação entre o objetivo geral proposto e os específicos e a conclusão alcançada, observações sobre os resultados, a resposta à pergunta da pesquisa, as limitações e contribuições do estudo e as recomendações sugeridas.

\subsection{Resultados alcançados}

O objetivo geral deste estudo de pesquisa foi identificar o estágio de maturidade atual quanto ao alinhamento entre o PEE e o PETI no Sicoob Confederação.

No Capítulo 4 - Resultados e Discussão foram elencados, dentro do modelo adotado, os resultados e a análise dos dados obtidos pelas respostas dos 
questionários aplicados, evidenciando quais construtos contribuem em menor ou menor grau para o alinhamento entre o PEE e o PETI.

$\mathrm{Na}$ primeira parte, Subcapítulo 4.3.1, foram avaliadas as respostas das variáveis que compõem cada construto, tendo como base as perguntas fechadas do questionário da pesquisa. De acordo com as médias gerais apuradas o construto que mais contribui para o alinhamento do PEE ao PETI é o Contexto Organizacional com 27,9\% das respostas "a", seguido do construto Tecnologia da Informação e Sistemas de Informação e do Conhecimento, ambos com $26,6 \%$ das respostas "a".

O construto que obteve a média geral mais baixa foi de Pessoas ou Recursos Humanos com 18,6 das respostas "a" que, pelo modelo de Rezende, representa a menor contribuição para a promoção do alinhamento estratégico.

A média geral considerando-se os quatro construtos avaliados foi de $24,9 \%$ de alinhamento baseado nas respostas "a" do questionário fechado.

$\mathrm{Na}$ segunda parte, Subcapítulo 4.3.2, foi analisado o percentual de alinhamento do PEE ao PETI, tendo como base a primeira pergunta aberta do questionário. Nesse caso, pela percepção dos gestores e analistas da área de TI do Sicoob, a média observada foi de $42,6 \%$, mais alta, portanto, que a média verificada nas respostas das variáveis.

Pelos resultados apresentados nos dois tipos de análise, observou-se uma diferença de $17,7 \%$ entre a média do questionário com perguntas fechadas e a média obtida com as respostas da pergunta aberta. Essa diferença pode ser explicada pelo fato das respostas abertas do questionário permitirem a expressão das percepções individuais dos entrevistados, que carregam um viés pessoal quanto á sua visão sistêmica da organização.

Por todos os resultados verificados nas análises pode-se concluir que o nível de maturidade do alinhamento estratégico da organização estudada é baixo e pode ser atribuído ao fato da empresa só ter realizado apenas um PEE, em 2009, enquanto que a área de TI já possuía várias edições anteriores do PETI. Outro fator que deve ser levado em consideração é quanto ao posicionamento da TI dentro do Sicoob. Até três anos atrás a TI fazia parte do Bancoob que, por sua vez, possuía elaborava seu PEE baseados somente nos negócios do banco, enquanto que a $\mathrm{TI}$ tinha que alcançar também os seus outros clientes que eram as centrais e as cooperativas, além do Bancoob. A partir da transferência da TI para o Sicoob Confederação as condições para um melhor alinhamento entre o PEE e o PETI 
foram estabelecidas, tendo em vista o maior alcance dos objetivos estratégicos da Confederação que contempla as cooperativas, as centrais e o banco.

Como essa mudança é relativamente recente podemos constatar que ainda não houve um tempo suficiente para que os processos de elaboração dos planejamentos estratégicos da organização sejam realizados de forma mais homogênea. Além disso, há também que se considerar que nesse meio tempo as áreas ainda estão se entrosando, motivo pelo qual a Confederação está investindo fortemente em programas de desenvolvimento humano voltados para aprimorar as habilidades relacionadas às atividades coletivas e participativas da organização.

\subsection{Relação entre os objetivos da pesquisa e a conclusão alcançada}

No que diz respeito ao primeiro objetivo específico de "identificar como são formulados os PEE e PETI da empresa", eles foram descritos nos subcapítulos 3.4 Metodologia de formulação do PEE do Sicoob e 3.5 Metodologia de formulação do PETI do Sicoob.

De acordo com a conclusão do objetivo geral, identifica-se que a formulação dos planejamentos estratégicos de negócios e de TI não estão seguindo exatamente uma mesma metodologia. É importante ressaltar novamente a questão do PETI possuir um processo de elaboração mais frequente, por conta das suas várias edições publicadas contra apenas uma do PEE.

O segundo objetivo específico de "Estabelecer e aplicar um modelo de mensuração para a aferição do grau de maturidade do alinhamento estratégico entre os negócios e a TI, baseado em pesquisa com os gerentes e analistas da área de $\mathrm{TI}$ do Sicoob Brasil" também foi alcançado a partir do estabelecimento de um modelo, o de Rezende (2002), conforme o Capítulo 3 - Métodos e técnicas de pesquisa e da aplicação desse modelo de acordo com o relatado no Capítulo 4 - Resultados e discussão.

O terceiro objetivo específico de "Identificar, através do modelo adotado para a mensuração do alinhamento estratégico, quais os recursos sustentadores 
que mais contribuem para o alinhamento estratégico entre o PEE e o PETI da empresa" também foi realizado e as considerações sobre a análise dos resultados estão contempladas no capítulo 4 - "Resultados e Discussão".

O quarto objetivo específico de "Identificar, através do modelo adotado, quais os recursos sustentadores que precisam ser mais bem trabalhados a fim de promoverem um maior alinhamento estratégico entre o PEE e o PETI da empresa" também foi realizado e as considerações sobre a análise dos resultados estão contempladas no capítulo 4 - "Resultados e Discussão".

Dessa forma o objetivo geral de "Identificar o estágio de maturidade atual quanto ao alinhamento entre o Plano Estratégico de Negócios (PEE) e o Plano Estratégico de TI (PETI) no Sicoob Brasil" foi alcançado plenamente e pode ser demonstrado nas diversas análises e conclusões realizadas.

\subsection{Considerações sobre os resultados}

Os resultados desse estudo apresentaram elementos que poderão contribuir para o aprimoramento dos processos de elaboração e acompanhamento dos planejamentos estratégicos de negócios e de TI do Sicoob Confederação. Esses resultados reiteram a importância do alinhamento do PETI ao PEE como uma ferramenta capaz de auxiliar a gestão da organização. Além disso, ratificam a visão moderna do planejamento da TI alinhada ao negócio empresarial e que contempla a visão sistêmica da organização, ao contrário da visão convencional do Plano Diretor de Informática, cujo foco recaia sobre as soluções tecnológicas muitas vezes sem considerar o PEE.

Um dos grandes desafios diz respeito à efetiva realização do alinhamento do PETI ao PEE na prática cotidiana da organização, associando as competências dos acadêmicos às competências dos gestores da organização. Nesse sentido, a análise desse estudo buscou apontar os principais recursos sustentadores do alinhamento do PETI ao PEE, indicando as variáveis mais relevantes e que merecem maior atenção para mitigar esse desafio. 


\subsection{Resposta à pergunta da pesquisa}

Com relação ao problema da pesquisa e sua pergunta, "Qual o estágio de maturidade atual quanto ao alinhamento entre o Plano Estratégico de Negócios e o Plano Estratégico de TI no Sicoob Confederação", pode-se afirmar que foi plenamente respondida a partir das observações, análises e conclusões já demonstradas neste estudo.

Apesar dos resultados terem apontado um baixo estágio de maturidade quanto ao alinhamento estratégico, pode-se constatar na prática que o Sicoob Confederação tem atingido ótimos resultados de desempenho e crescimento no cenário financeiro brasileiro, já figurando como a sexta instituição em número de pontos de atendimento, segundo a Revista Exame Maiores e Melhores, atrás da Caixa Econômica Federal que ocupa a quinta colocação.

Essas evidências são indicativas de que o Sicoob, apesar de estar numa boa posição no mercado financeiro nacional, poderá otimizar mais ainda seus resultados pela promoção de um melhor alinhamento entre o PEE e o PETI.

\subsection{Limitações e contribuições do estudo}

Algumas limitações foram verificadas ao longo do estudo, principalmente na fase de pré-teste e aplicação do questionário, em virtude da dificuldade de conquistar uma quantidade maior de entrevistados. Muitos dos convidados a participar da pesquisa alegaram indisponibilidade de tempo para responder ao questionário proposto e outros não completaram as respostas no prazo combinado. Dessa forma o estudo ficou limitado, por conveniência, à participação de quinze respondentes, entre gerentes e analistas da área de TI do Sicoob.

Outra limitação tem relação com análise quantitativa e quanti-qualitativa dos dados dos questionários que não retrata fielmente a realidade do Sicoob Confederação. Os instrumentos de coleta e análise de dados buscavam somente 
identificar as variáveis dos recursos sustentadores do alinhamento estratégico sem, no entanto, aprofundar rigorosamente nas particularidades da organização.

Com relação ao modelo de Rezende adotado para a pesquisa, seria desejável que o estudo pudesse adotar adicionalmente outros modelos de forma a apresentar maior riqueza de investigação e consequentemente resultados mais precisos.

Como contribuição acadêmica espera-se que esta pesquisa possa contribuir para a discussão do tema em estudo auxiliando a sua compreensão. $O$ referencial teórico apresentou uma visão conceitual sobre estratégias, vantagem competitiva, planejamento estratégico e alinhamento entre PEE e PETI, possibilitando um melhor entendimento sobre o objeto da pesquisa expressando 0 pensamento de autores clássicos e contemporâneos da Administração.

Como contribuição gerencial é esperado que esta pesquisa venha a estimular outras organizações a avaliar o nível de maturidade do alinhamento entre os seus planejamentos estratégicos de negócios e de TI. Este estudo fornece meios para identificar onde a organização se situa e para onde deve ser direcionada, com a intenção de alcançar e sustentar o alinhamento entre negócios e TI.

Especialmente para a organização estudada, este trabalho prestou-se a avaliar o nível de maturidade e a percepção individual dos gerentes e analistas da área de TI quanto ao alinhamento estratégico entre negócios e TI implantado no Sicoob, de forma a apontar as boas práticas em uso e aquelas que necessitam de melhorias, viabilizando a sustentação e o incremento do alinhamento estratégico.

\subsection{Recomendações sugeridas}

Esta pesquisa identificou, para a organização estudada, algumas recomendações quanto a ações e procedimentos que devem ser objeto de atenção por parte de seus gestores a fim de que a empresa mantenha e incremente o nível de maturidade do alinhamento estratégico entre os planos de negócios e de TI.

$O$ fato dos resultados da pesquisa indicarem que o construto Pessoas ou Recursos Humanos é o que menos contribui para o alinhamento estratégico do Siccob aponta para a necessidade da organização investigar com maior acuidade 0 
assunto, revendo seus objetivos de investimentos em programas de desenvolvimento humano e intensificando incentivos ao aprimoramento pessoal dos funcionários. Também deve ser reavaliado o plano de cargos e salários da empresa, mantendo compatibilidade com o mercado e criando novas oportunidades para o crescimento profissional dos funcionários, mantendo-os motivados para desempenho de suas funções cotidianas.

Outro aspecto que também deve ser melhor avaliado pela empresa é a proporção atual de funcionários terceirizados na área de $\mathrm{TI}$, o que não ocorre na área de negócios onde todos os colaboradores pertencem ao quadro de funcionários da organização. O alto nível de terceirização muitas vezes gera situações onde se verifica diferenças quanto ao comprometimento e envolvimento dos colaboradores com relação a atividades de cunho mais estratégico da organização. Há ainda as disparidades de remuneração já que entre os terceirizados existem os que são remunerados pelo regime da CLT - Consolidação das Leis Trabalhistas e os que são contratados como pessoas jurídicas.

Observando ainda os resultados obtidos na pesquisa seria conveniente que - Sicoob promovesse uma maior participação dos profissionais das áreas de negócios e de TI nas atividades pertinentes ao PEE e ao PETI. Atualmente o maior envolvimento nessas atividades se dá entre os gestores da organização.

Embora o construto $\mathrm{RH}$ seja o que menos contribui para o alinhamento, as médias percentuais obtidas para os construtos $\mathrm{TI}$, SI e CO ficaram em níveis que merecem ser objeto de avaliação pelo Sicoob.

Finalmente, quanto ao acompanhamento da execução dos planos de negócios e de TI, é altamente recomendável que o Sicoob estabeleça critérios com métricas claras para uma constante avaliação do alinhamento entre os mesmos e promova uma comunicação eficiente desses resultados a toda corporação.

\subsection{Considerações finais}

O presente estudo teve como objetivo avaliar o nível de alinhamento entre - PEE e o PETI do Sicoob Confederação, o que permite identificar onde a organização está situada e para onde deve ser direcionada, de modo a obter e 
sustentar o alinhamento estratégico. De modo empírico, não é fácil determinar com precisão qual o estágio de maturidade a organização se encontra, já que para cada um dos critérios utilizados para esta avaliação, um nível diferente pode ser encontrado (BRODBECK et al, 2007).

A pesquisa elaborada junto aos gerentes e analistas da área de $\mathrm{TI}$ do Sicoob, permitiu concluir, através da análise das variáveis que compõem os construtos do modelo de Rezende (2008), que o nível de maturidade do alinhamento estratégico da organização estudada é baixo.

Esse resultado corrobora com a visão de Rezende (2008, p. 114), que preconiza que o alinhamento entre os planejamentos estratégicos de negócios e de $\mathrm{TI}$ acontece quando é sustentado pelos coerentes, adequados e essenciais recursos sustentadores: tecnologia da informação, sistemas de informações e do conhecimento, pessoas ou recursos humanos e contexto organizacional.

Para a organização avaliada, este estudo propôs uma série de recomendações relacionadas a ações e procedimentos que devem ter tratamento especial por parte dos seus gestores, de forma que ela possa manter e desenvolver o nível de maturidade do alinhamento estratégico entre o PEE o e PETI.

Quanto às contribuições acadêmicas e desdobramentos desta pesquisa, deve-se ressaltar o fato de o alinhamento estratégico ainda ser considerado como um conceito nebuloso, que não é fácil de ser compreendido e mensurado, não obstante os esforços acadêmicos empreendidos nessa área (CHAN et al., 1997;CHAN e REICH, 2007).

É de se esperar que este estudo traga contribuições para a discussão do tema alinhamento estratégico entre PEE e PETI, fornecendo subsídios para o seu amplo entendimento.

O referencial teórico apresentado procurou mostrar a visão de autores clássicos e contemporâneos sobre os conceitos que envolvem as estratégias empresariais, a estratégia competitiva, a vantagem competitiva da TI, PEE, PETI e alinhamento estratégico.

Como contribuições gerenciais e desdobramentos desta pesquisa, deve-se considerar o fato do alinhamento estratégico ser considerado ainda pouco entendido e praticado pelas organizações brasileiras (BRODBECK et al., 2005; RIGONI et al., 2006). Dessa forma, espera-se que essa pesquisa, ao estudar uma empresa brasileira, que atua no mercado financeiro e que é fortemente suportada por $\mathrm{TI}$, 
possa contribuir para disseminar os conceitos de alinhamento estratégico e estimulálos na prática cotidiana das organizações.

Além das contribuições, um estudo identifica limitações que devem ser tratadas de modo claro e aberto, antes mesmo de receber as críticas, assumindo que não existe projeto perfeito (PATTON, 1990). Dessa forma, durante o desenvolvimento da pesquisa, foram observadas algumas deficiências e restrições que podem de alguma forma ter influenciado o seu resultado. Segundo Scandura e Wiliams (2000), percepções carregam sempre um viés característico e que dificilmente pode ser retirado. Nessa linha, há que se considerar que os gerentes e analistas de $\mathrm{TI}$ do Sicoob Confederação envolvidos nesta pesquisa exprimiram suas percepções decorrentes da visão pessoal que cada um tem sobre a empresa.

Este trabalho procurou mostrar que as organizações com um elevado nível de alinhamento estratégico têm mais condições de fazer um melhor uso estratégico da TI e obter melhores resultados. Os resultados da pesquisa evidenciaram elementos que poderão embasar futuros estudos e mostraram a relevância da sinergia que deve existir entre as áreas da organização para o alcance dos resultados esperados. 


\section{REFERÊNCIAS}

ALBERTIN, A. L. Valor estratégico dos projetos de tecnologia de informação, Revista de Administração de Empresas, São Paulo, v. 41, n.3, p. 42-50, jul./set. 2001.

ALECRIM, E. O que é Tecnologia da Informação (TI)?, 2004 - Info Wester. Disponível em < http://www.infowester.com/col150804.php>. Acesso em: 15/01/2011.

AMARAL, L.; VAREJÃO, J. Planejamento de Sistemas de Informação. Lisboa: Editora FCA, 2007.

ANDREWS, Kenneth. O conceito de estratégia empresarial. In: MINTZBERG, Henry; QUINN, James B. O processo da estratégia. Bookman. Porto Alegre, 2001

ANSOFF, H.I. A Nova Estratégia Empresarial. São Paulo: Editora Atlas, 1990.

ANSOFF, H. I.; MCDONNELL, E. J. Implanting strategic management. Englewood Cliffs: Prentice Hall, 1984

BARRETO, A. V. P.; HONORATO, C. de F. Manual de sobrevivência na selva acadêmica. Rio de Janeiro: Objeto Direto, 1998.

BOWMAN, B.; DAVIS, G.; WETHERBE, J. Three Stage of MIS Planning, Information \& Management, Vol. 6, no 1, p. 11-25, 1983.

BOAR, B. Tecnologia da Informação: A arte do planejamento estratégico. São Paulo: Berkeley, 2002.

BORN, R. Desvendando o planejamento estratégico. Porto Alegre, Sulina, 2006.

BRODBECK, A. et al. Uma Análise do Nível de Maturidade do Alinhamento Estratégico entre Negócio e Tecnologia da Informação. In: XXXI EnANPAD, 2007, Rio de Janeiro. Anais... 2007.

BRODBECK, A. et al. Práticas de Alinhamento Estratégico Promovidas em Organizações do Estado do Rio Grande do Sul. In: ENANPAD, 2005, Brasília. Anais...Porto Alegre: ENANPAD, v.1, p.1-16, 2005.

CASTRO, L. P. V. O papel da tecnologia da informação na compreensão do gestor público estadual. Fortaleza, 2004. Dissertação (mestrado) - CMPAd/UEC.

CECATO, C. O importante não é apagar incêndios e sim planejar. Bannas Qualidade, São Paulo, abril 2002. 
CHAN, Y. et al. Business Strategic Orientation, Information Systems Strategic Orientation, and Strategic Alignment. Information Systems Research, v.8, n.2, p-125150, Jun. 1997.

CHAN, Y. e REICH, B. IT Alignment: What Have we Learned? Journal of Information Technology, v. 22, p.297-315, 2007.

DRUCKER, P. F. Introdução à Administração. São Paulo: Pioneira, 1999.

DRUCKER, P. F. Administrando em Tempos de Grandes Mudanças. São Paulo: Pioneira, 1996.

Earl, M. J. Information Management: The Strategic Dimension. Clarendon Press: Oxford, 1990.

EARL, M. J. Experiences in Strategic Information Systems Planning. MIS Quarterly, 17(1): 1-24, 1993.

FECHIO, J. A. Planejamento estratégico. Computerworld. mar. 2001.

FERNANDES, J. M. Gestão da Tecnologia como Parte da Estratégia Competitiva das Empresas. Brasília: IPDE, 2003.

FOINA, P. R. Tecnologia da Informação: Planejamento e Gestão. São Paulo: Atlas, 2001.

FREITAS, P. L. C. Alinhamento Estratégico entre os Planos de Tecnologia da Informação e os Planos de Negócio: uma análise dos fatores influenciadores. Santa Maria, 2007. Dissertação (mestrado) - UFSM. Multicopiada.

GALLIERS, R. D. Information Analysis: Selected Readings, AddisonWesley, 1987.

GIL, A. C. Métodos e Técnicas de Pesquisa Social. 15ª ed. São Paulo:

Atlas, 1999.

GOLDMAN, S.; NAGEL, R.; PREIS, K. Agile Competitors and Virtual Organizations: strategies for enriching the customer. Nova lorque: Van Nostrand Reinhold, 1995. In: O'BRIEN, J. A. Sistemas de informações e as decisões gerenciais na era da Internet. São Paulo: Saraiva, 2002.

GRAEML, A. R. Sistemas de Informações: o alinhamento de estratégia de TI com a estratégia corporativa. São Paulo: Atlas, 2000.

HAIR, J. et al. Multivariate data analysis. 5. ed. Upper Saddle River: Prentice-Hall, 1998.

HENDERSON, J.C.; VENKATRAMAN, N. Strategic Alignment: Leveraging Information Technology For Transforming Organizations. IBM Systems Journal. v.32, n.1, p.4-16, 1993. 
ITGI, “COBIT 3rd Edition”, IT Governance Institute. 2005.

ITGI, “COBIT 3rd Edition”, IT Governance Institute. 2007.

KING, W. R. Strategic planning for MIS. MIS Quarterly, v. 2, n.1, p. 27-37, Mar. 1978.

KOTLER, P.; ARMASTRONG, G. Princípios de marketing. Rio de Janeiro: PrenticeHall, 2000.

LAURINDO, F. J. B; SHIMIZU, T.; CARVALHO, M. M. et al. O papel da tecnologia da informação (TI) na estratégia das organizações. Gest. Prod., Aug. 2001, vol.8, no. 2, p.160-179. ISSN 0104-530X.

LEDERER, A.L.; GARDINER, V. The process of strategic information planning. Journal of strategic Information Systems, Vol. 1, p. 76-83, 1992.

LEDERER, A. L.; SALMELA, H. Toward a theory of strategic information systems 85 planning. Jornaul of Strategic Information Systems. 5(3), 1996, pp.237-253.

LEDERER, A. L.;MENDELOW, A.L. The Impact of the Environment on the Management of Information Systems. Information Systems Research, 1(2), jun. 1990, p.205-222.

LUTCHEN, M. D. Managing IT as a business: a survival guide for CEOs. Wiley, 2004.

MALHOTRA, N. K. Pesquisa de marketing: uma orientacão aplicada. 3. ed. Porto Alegre. Bookman, 2002.

MARCONI, M. A.; LAKATOS, E. M. Técnicas de pesquisa. 3. ed. São Paulo: Atlas, 1996.

MARTIN, J. Engenharia da informação. Rio de Janeiro: Campus, 1989.

MAXIMIANO, A. C. A.. Introdução à administração. São Paulo: Atlas, 2000.

McGEE, J.; PRUSAK, L. Gerenciamento Estratégico da Informação. Rio de Janeiro: Campus, 1994.

MEIRELLES, F. Gastos, investimentos e indicadores nas empresas: evolução e tendências. In: ALBERTIN, A; MOURA, R. (org.).Tecnologia de Informação. Atlas. São Paulo, 2004.

MIN, S.K., SUH, E.H., KIM, S.Y. An integrated approach toward strategic information systems planning. Journal of Strategic Information Systems, n. 8, p. 373-394, 1999.

MINTZBERG, H.; AHLSTRAND, B.; LAMPEL, J. Safari de estratégia: um roteiro pela selva do planejamento estratégico. Porto Alegre: Bookman, 2000. 
MINTZBERG, H; QUINN, J. B. O processo da estratégia. 3. ed. Porto Alegre: Bookman, 2001.

MINTZBERG, H.; LAMPEL, J; QUINN, J. B.; GHOSHAL, S. O Processo da Estratégia: conceitos, contextos e casos selecionados. Porto Alegre: Bookman, 2006.

MORTON, M. S. The Corporation of the 1990s: information technology and organizational transformation. New York: Oxford University Press, 1991.

NOLAN, R. L. Note on information technology and strategy. Boston: Harvard Business School, 1993.

O'BRIEN, J. A. Sistemas de informações e as decisões gerenciais na era da Internet. São Paulo: Saraiva, 2002.

OLIVEIRA, D. P. R. Planejamento estratégico: conceitos, metodologia e prática. São Paulo: Atlas, 2005.

PATTON, M. Q. Qualitative evaluation and research methods. 2nd. ed. Newbury Park, CA: Sage, 1990.

PEREIRA, J. M. Manual de Gestão Pública Contemporânea. São Paulo: Atlas, 2007.

PORTER, M. Towards a Dynamic Theory of Strategy. Strategic Management Journal, v.12, p.95-117, 1991.

PORTER, M. Vantagem Competitiva: criando e sustentando um desempenho superior. Rio de Janeiro: Elsevier, 1989.

PORTER, M. Estratégia Competitiva: técnicas para análise da indústria e da concorrência. 7ed. Rio de Janeiro: Campus, 1986.

PORTER, M.; MILLAR, V. E. Como a Informação Proporciona Vantagem Competitiva. Harvard Business Review, Julho-Agosto, 1985. In: PORTER, M. E. Competição: estratégias competitivas essenciais. 8.ed. Rio de Janeiro: Campus, 1999.

PREMKUMAR, G.; KING, W. R. Organizational characteristics and information system planning: an empirical study. Information System Research, v. 5, no 2, p. 75109, 1994.

RAGHUNATHAN, T. S.; KING, W. R. The Impact of Information Systems Planning on the Organization, Omega, 16 (1988), 85-93.

RAGHUNATHAN, B.; RAGHUNATHAN, T.S. Adaptation of a Planning System Success Model to Information Systems Planning, Information Systems Research, 5, 3 (1994), 326-34. 
RAMARAJ, P. Strategic information systems planning model for building flexibility and success, Industrial Management \& Data Systems, Vol. 105 Iss: 1, pp.63 - 81, 2005.

REA, L. M.; PARKER, R. Metodologia da pesquisa: do planejamento à execução. São Paulo: Pioneira Thomson Learning, 2002.

REPONEN, T. Organizational information management strategies, Information Systems Journal, 4, 1 (1994), 27-44.

REZENDE, D. A. Tecnologia da Informação e Planejamento Estratégico: Alinhamento e Integração com a Inteligência Organizacional Privada ou Pública. Rio de Janeiro: Brasport, 2008.

REZENDE, D. A. Tecnologia da Informação Integrada à Inteligência Empresarial: alinhamento estratégico e análise da prática nas organizações. São Paulo: Atlas, 2002.

REZENDE, D. A. Alinhamento do planejamento estratégico da tecnologia da informação ao planejamento empresarial: proposta de um modelo e verificação da prática em grandes empresas brasileiras. 2002. Tese (Doutorado em Engenharia de Produção - Gestão da Tecnologia da Informação) Florianópolis: EPS/UFSC.

REZENDE, D. A.; ABREU, A. F. de. Planejamento Estratégico da Tecnologia de Informação Alinhado ao Planejamento Estratégico de Empresas. São Paulo, Revista de Administração Mackenzie Ano 3, n.2, p. 39-51, 2002.

REZENDE, D. A.; ABREU, A. F. de; PEREIRA, R. O. Geração de informações oportunas ou conhecimento para auxiliar nos processos decisórios empresariais das organizações que utilizam tecnologia da informação. I Congresso de Lógica aplicada à Tecnologia - LAPTEC. São Paulo, setembro de 2000.

REZENDE, D.A.; ABREU, A. F. Recursos sustentadores do alinhamento estratégico da tecnologia da informação ao negócio empresarial: proposta de um modelo e verificação da prática em grandes empresas brasileiras. In: ENCONTRO ANUAL DA ANPAD, 2002, Salvador. Anais ... Salvador: ANPAD, 2002.

RIGONI, E. et al. Percepções de Executivos de TI e de Negócios em Relação ao Alinhamento Estratégico Promovido em Indústrias do Estado do Rio Grande do Sul. In: XXX EnANPAD, 2006. Salvador. Anais... 2006.

SACCOL, I. C. Z. Alinhamento Estratégico da Utilização da Internet e do Comércio Eletrônico: os casos Magazine Luiza e Fleury. Revista de Administração Contemporânea, v. 09, no 2, Abr, Mai e Jun, 2005. Disponível em: $<$ http://www.anpad.org.br/periodicos/content/frame_base.php?revista=1>. Acesso em: 8 de maio de 2010.

SCANDURA T. e WILLIAMS E. Research Methodology in Management: Current Practices, Trends, and Implications for Future Research. The Academy of Management Journal, v.43, n.6, p.1248-1264, 2000. 
SCHILLING, VOLTAIRE/História por - Atualidade - Globalização, ontem e hoje. Disponível em <http://educaterra.terra.com.br/voltaire/atualidade/globalizacao.htm>. Acesso em: 15/04/2010.

SERRA, F. A. R.; TORRES, A. P. TORRES, M. C. S. Administração estratégica: conceito, roteiros práticos e casos. Rio de Janeiro: Reichmann \& Affonso Editores, 2004.

TRAVIÑOS, Augusto N. S. Introdução à pesquisa em ciências sociais: a pesquisa qualitativa em educação. São Paulo: Atlas, 1987.

VITALE, M. R.; IVES, B.; BEATH, C. M. Linking information technology and corporate strategy: An organizational view. Proceedings of the 7th International Conference on Information Systems, San Diego, California, pp. 265-276, 1986.

WARD, J.; GRIFFITHS, P.; WHITMORE, P. Strategic Planning of Information Systems, John Wiley \& Sons, 1996.

WIENER, N. In. Krishan Kumar (org.). Da sociedade pós industrial á pós moderna: novas teorias sobre o mundo contemporâneo. Rio de Janeiro: Jorge Zahar, 1997.

WISEMAN, C. Strategy and computers: Information Systems as Competitive Weapons. ed. Homewood-EUA, Dow-Jones Irwin, 1985. 


\section{ANEXOS}

\section{Anexo 1 - Questionário}

Informações preliminares sobre o questionário

As perguntas do questionário são dirigidas aos gestores e colaboradores mais experientes da área de $\mathrm{Tl}$ e devem ser respondidas separadamente. As perguntas têm como base a revisão da literatura, obedecendo a um critério em escala de cinco possibilidades que representam a opinião sobre uma afirmação. A escala tem o princípio de funcionamento de uma balança tipo gangorra e a opinião deve ser respondida como um peso que a equilibra (indiferente) ou desequilibra para algum dos lados (discordando ou concordando). É importante ressaltar que as respostas devem considerar sempre a situação atual da organização, procurando evitar a opinião de condições passadas, expectativas futuras ou anseios pessoais.

Ao final dos questionários haverá um espaço para comentários adicionais ou outras observações.

\section{Identificação do respondente}

\begin{tabular}{|l|l|}
\hline Respondente & \\
\hline Cargo & \\
\hline Formação acadêmica & \\
\hline Pós-graduação & \\
\hline Idade & \\
\hline Tempo de empresa & \\
\hline Tempo de experiência & \\
\hline
\end{tabular}

\section{Perguntas}




\section{Parte I - Tecnologia da Informação (TI)}

1. Os computadores, seus dispositivos e periféricos utilizados

a. Estão totalmente adequados à estratégia da organização

b. Estão parcialmente adequados à estratégia da organização

c. São indiferentes quanto a adequação à estratégia da organização

d. Estão inadequados à estratégia da organização

e. Estão totalmente inadequados à estratégia da organização

2. Os sistemas operacionais, os utilitários e os aplicativos office utilizados

a. Estão totalmente adequados à estratégia da organização

b. Estão parcialmente adequados à estratégia da organização

c. São indiferentes quanto a adequação à estratégia da organização

d. Estão inadequados à estratégia da organização

e. Estão totalmente inadequados à estratégia da organização

3.Os sistemas de telecomunicações, as redes e seus recursos de teleprocessamento utilizados

a. Estão totalmente adequados à estratégia da organização

b. Estão parcialmente adequados à estratégia da organização

c. São indiferentes quanto a adequação à estratégia da organização

d. Estão inadequados à estratégia da organização

e. Estão totalmente inadequados à estratégia da organização

4. As tecnologias para administração e gestão de dados e de informações

a. Estão totalmente adequados à estratégia da organização

b. Estão parcialmente adequados à estratégia da organização

c. São indiferentes quanto a adequação à estratégia da organização

d. Estão inadequados à estratégia da organização

e. Estão totalmente inadequados à estratégia da organização

5. A TI e seus recursos de hardware, software, sistemas de telecomunicações e tecnologias para administração e gestão de dados e de informações 
a. Foram totalmente planejados com criteriosa Análise de Custos, Benefícios e Viabilidades

b. Foram parcialmente planejados com Análise de Custos, Benefícios e Viabilidades

c. São indiferentes Quanto a planejamento com Análise de Custos, Benefícios e Viabilidades

d. Não foram planejados para atender a criteriosa Análise de Custos, Benefícios e Viabilidades

e. Estão sem qualquer planejamento quanto a Análise de Custos, Benefícios e Viabilidades

Complemente, justifique e exemplifique as respostas fornecidas (digite aqui ou use o verso).

\section{Parte II - Sistemas de Informação e do Conhecimento (SI)}

1. Os SI Operacionais que processam as operações e transações rotineiras quotidianas com seus respectivos procedimentos no seu detalhe

a. Estão totalmente adequados à estratégia da organização

b. Estão parcialmente adequados à estratégia da organização

c. São indiferentes Quanto a adequação à estratégia da organização

d. Estão inadequados à estratégia da organização

e. Estão totalmente inadequados à estratégia da organização ou inexistem

2. Os SI Gerenciais que processam os grupos de dados das operações e das transações operacionais empresariais

a. Estão totalmente adequados à estratégia da organização

b. Estão parcialmente adequados à estratégia da organização

c. São indiferentes quanto a adequação à estratégia da organização

d. Estão inadequados à estratégia da organização

e. Estão totalmente inadequados à estratégia da organização ou inexistem

3. Os SI Estratégicos que processam os grupos de dados das operações e das transações gerenciais

a. Estão totalmente adequados à estratégia da organização 
b. Estão parcialmente adequados à estratégia da organização

c. São indiferentes quanto a adequação à estratégia da organização

d. Estão inadequados à estratégia da organização

e. Estão totalmente inadequados à estratégia da organização ou inexistem

4. Os SI do Conhecimento

a. Auxiliam totalmente a tomada de decisão de todos na organização

b. Auxiliam parcialmente a tomada de decisão de todos na organização

c. São indiferentes quanto a auxiliar a tomada de decisão de todos na organização

d. Não auxiliam a tomada de decisão de todos na organização

e. Inexistem

5. Todos os SI da organização

a. Possuem completa tecnologia de administração de base de dados para eliminar informações redundantes na organização

b. Possuem parcial tecnologia de administração de base de dados, permitindo algumas informações redundantes na organização

c. São indiferentes quanto a redundância de dados

d. Não possuem tecnologia de administração de base de dados para evitar informações redundantes na organização, permitindo a existência de informações redundantes

e. Possuem informações redundantes, independente da existência de tecnologias de administração de base de dados

Complemente, justifique e exemplifique as respostas fornecidas (digite aqui ou use 0 verso).

\section{Parte III - Pessoas ou Recursos Humanos (RH)}

1. Os valores humanos, éticos e morais das pessoas da organização

a. São totalmente expressos nas atividades coletivas e participativas da organização

b. São parcialmente expressos nas atividades coletivas e participativas da organização

c. São indiferentes para a organização 
d. Não são expressos nas atividades coletivas e participativas da organização

e. Inexistem esses valores ou inexistem as atividades coletivas e participativas na organização

2. Os profissionais da equipe da TI da organização (técnicos da TI)

a. São constantemente capacitados nas suas atividades

b. São frequentemente capacitados nas suas atividades

c. É indiferente para a organização

d. Não são capacitados nas suas atividades

e. Inexiste essa exigência de capacitação dos profissionais da TI

3. As atividades pertinentes ao PEE e ao PETI

a. São totalmente elaboradas por equipe multidisciplinar que preserva os talentos internos da organização

b. São parcialmente elaboradas por equipe multidisciplinar que preserva os talentos internos

c. São indiferentes para a organização

d. Não são elaboradas por equipe multidisciplinar que preserva os talentos internos

e. Inexiste essa necessidade de equipe multidisciplinar as atividades de planejamento

4. A troca de experiências e de aprendizado entre os profissionais envolvidos nas atividades de planejamento da organização

a. É totalmente promovida pela organização

b. É parcialmente promovida pela organização

c. É indiferente para a organização

d. Não é promovida pela organização

e. Inexiste essa necessidade troca de experiências e de aprendizado desses profissionais

5. O clima no ambiente de trabalho da organização

a. Facilita completamente as atividades de planejamento da organização

b. Facilita parcialmente as atividades de planejamento da organização

c. É indiferente para a organização 

d. Não facilita as atividades de planejamento da organização
e. Inexiste essa necessidade de clima de trabalho na organização

Complemente, justifique e exemplifique as respostas fornecidas (digite aqui ou use 0 verso).

\section{Parte IV - Contexto Organizacional}

1. A missão, os objetivos e as estratégias da organização

a. Estão totalmente formuladas e claramente comunicadas para os envolvidos no PEE e no PETI

b. Estão parcialmente formuladas e comunicadas para os envolvidos no PEE e no PETI

c. É indiferente para a organização

d. Não estão formuladas e comunicadas para os envolvidos no PEE e no PETI

e. Inexiste essa necessidade de formulação

2. Os planos de ação relacionados ao PEE e ao PETI

a. Estão totalmente definidos, descritos e comunicados para os envolvidos nessas atividades

b. Estão parcialmente definidos, descritos e comunicados para os envolvidos nessas atividades

c. É indiferente para a organização

d. Não estão definidos, descritos e comunicados para os envolvidos nessas atividades

e. Inexiste essa necessidade ou inexistem os planos de ação do PEE e do PETI

3. A cultura, a filosofia e as políticas da organização

a. Estão totalmente transparentes, positivas e disseminadas

b. Estão parcialmente transparentes, positivas e disseminadas

c. É indiferente para a organização

d. Não estão transparentes, positivas e disseminadas

e. Inexiste essa necessidade de transparência e disseminação 
4. Os investimentos em $\mathrm{TI}$, em $\mathrm{SI}$, em recursos humanos e em infraestrutura organizacional
a. Estão totalmente previstos e precisamente quantificados no PEE
b. Estão parcialmente previstos e quantificados no PEE
c. É indiferente para a organização
d. Não estão previstos e quantificados no PEE
e. Inexiste essa necessidade de investimento

5. Os investimentos elaborados pela organização em $\mathrm{TI}$ e seus recursos para o PETI

a. Alcançam totalmente os resultados predefinidos

b. Alcançam parcialmente os resultados predefinidos

c. É indiferente para a organização

d. Não alcançam os resultados predefinidos

e. Inexiste essa necessidade alcançar os resultados predefinidos pela organização

Complemente, justifique e exemplifique as respostas fornecidas (digite aqui ou use o verso).

\section{Parte V - Alinhamento Estratégico}

1. As estratégias das funções empresariais de toda a organização

a. Estão totalmente identificadas e integradas na organização

b. Estão parcialmente identificadas e integradas na organização

c. É indiferente para a organização

d. Não estão identificadas e integradas na organização

e. Inexiste essa necessidade identificação e integração das funções empresariais na organização

2. As tecnologias disponíveis na organização (de TI e organizacional)

a. Estão totalmente adequadas à estratégia da organização

b. Estão parcialmente adequadas à estratégia da organização

c. São indiferentes quanto a adequação à estratégia da organização

d. Estão inadequadas à estratégia da organização

e. Estão totalmente inadequadas à estratégia da organização 


\section{A gestão do PETI}

a. Está totalmente adequada e alinhada à estratégia da organização

b. Está parcialmente adequada e alinhada à estratégia da organização

c. É indiferente quanto a adequação e alinhamento à estratégia da organização

d. Está inadequada e desalinhada à estratégia da organização

e. Está totalmente inadequada e desalinhada à estratégia da organização

\section{A gestão do PEE e do PETI}

a. É uma atividade de total parceria e cogestão integrada

b. É uma atividade de parcial parceria e cogestão integrada

c. É indiferente para a organização

d. Não é uma atividade de parceria e cogestão integrada

e. Inexiste essa necessidade de estabelecer parceria e cogestão integrada desses planejamentos

5. Os indicadores de mensuração ou critérios que permitem as avaliações dos resultados do PEE e do PETI

a. Estão totalmente definidos, descritos e comunicados aos envolvidos nessas atividades

b. Estão parcialmente definidos, descritos e comunicados aos envolvidos nessas atividades

c. É indiferente para a organização

d. Não estão definidos, descritos e comunicados para os envolvidos nessas atividades

e. Inexiste essa necessidade definição, descrição e comunicação destes critérios

Complemente, justifique e exemplifique as respostas fornecidas (digite aqui ou use o verso). 
1. Diante de todas essas respostas, qual o percentual de alinhamento entre 0 Planejamento Estratégico da Tecnologia da Informação e o Planejamento Estratégico Empresarial em sua organização?

2. Destaque os principais fatores que sustentam o alinhamento entre o Planejamento Estratégico da Tecnologia da Informação ao Planejamento Estratégico Empresarial de sua organização.

3. Utilize este espaço para seus comentários adicionais. 